VIVEK GUPTA

\title{
IMAGES FOR INSTRUCTION: A MULTILINGUAL ILLUSTRATED DICTIONARY IN FIFTEENTH-CENTURY SULTANATE INDIA
}

When I began studying the Miftăh al-Fu̇al $\bar{a}^{\prime}$ (Key of the Learned), Robert Skelton, the doyen of the art of the book in India, challenged me to imagine the many other manuscripts that would have been available to the artists who made this book. Attributed to the central Indian sultanate of Malwa, the Miftāh is the only known illustrated Persian dictionary (farhang) in the Islamicate manuscript tradition. For its fifteenth-century makers, the Miftāh was a wholly new text, written in 1468-69 by Muhammad ibn Muhammad Da'ud Shadiyabadi. The Miftā $h$ required its artists to search for and codify visual representations of particular words from canonized manuscript genres such as the Islamicate cosmography ('ajā'ib al-makhlūqāt) or works of belles-lettres (adab). This process of selectively adapting from an array of genres in order to create a new one, namely the illustrated farhang, would have allowed artists to experiment with the Islamicate manuscript tradition in India. By illustrating definitions, the Miftăh also became a manual on literary and visual languages for students in the fifteenth century. This article demonstrates that the book was conceived as a didactic work intended to educate members of sultanate society.

The text of the Miftāh is intensely multilingual. It provides definitions of Persian entries (lemmas) in Persian, frequently offering Arabic and Hindavi equivalents and occasional Turki or Chaghatai synonyms. Since medieval Persian literary sciences drew heavily from systems developed in Arabic, the presence of Arabic words is expected. Less obvious is the use of Hindavi and Turki. Hindavi is a premodern vernacular that eventually evolved into Urdu and Modern Hindi. It is the language used for Mawlana Da'ud's Chāndāyan (ca.1379), the Sufi romance that is illustrated in several fifteenth- and six- teenth-century manuscripts. ${ }^{1}$ Turki, or Chaghatai, is a Turkic literary language of Central Asia from the fourteenth to sixteenth centuries that was vernacularized in India. ${ }^{2}$ This period witnessed a rise in the importance of Chaghatai across regions. For example, in Khurasan's Timurid capital Herat, 'Ali Shir Nava'i (d. 1501) and Sultan Husayn Bayqara Mirza (d. 1506) promoted Chaghatai. ${ }^{3}$ Both Hindavi and Turki words are widespread in fifteenth-century Persian dictionaries from India.

In its interplay between the verbal and visual, the Miftăh serves as a model of sophisticated bookmaking. With a total of 306 folios, it contains 179 illustrations. Not every definition is illustrated, but the non-illustrated definitions relate to entries with paintings. Dictionary entries often include multiple definitions and meanings, and the illustrations of the Miftăh sometimes conflate the multiple meanings of a single word as a playful visual pun. ${ }^{4}$ A single illustration can also depict multiple adjacent entries simultaneously. ${ }^{5}$ Illustrations frequently transcend textual definitions, inspiring reinterpretations of the text. Some entries establish synonyms that are both textual and visual and demonstrate that artists were involved in a range of philological processes, such as making equivalences. For instance, there are two different lemmas and corresponding illustrations for the definitions of turtle, porcupine, monkey, animal den, and yawn. ${ }^{6}$

While previous scholarship has emphasized the significance of the Persian farhang for understanding poetry and its authorship, I show how the Miftāh leads its readers to manuscript genres beyond the realm of poetry. ${ }^{7}$ In searching for manuscript genres related to the Miftāh, I have found that cosmographies exhibit several formal similarities. Like late fifteenth-century Persian

(C) VIVEK GUPTA, 2021 | DOI:10.1163/22118993-00381P04

This is an open access article distributed under the terms of the CC BY 4.o license. 
cosmographies, the Miftạh's illustrations are inserted adjacent to the entries to which they correspond. ${ }^{8}$ Executed on the same paper as the text, the paintings are placed within rectangular boxes of minimal ruling in black ink, and their sizes vary considerably. Certain court scenes stretch across a page, whereas animals tend to occupy less space (figs. 1, 2). ${ }^{9}$ Occasionally illustrations flow into the margins. Although the same layout is also used for books besides the wonders-of-creation cosmography (fig. 3), such as the bestiary or pharmacopeia, the sheer diversity of illustration types within cosmographies provides the closest analogy to the scope and themes of illustrations found in the Miftāh. In the final section of this article, I explain ways in which the
Miftāh's text and images point to a clear relationship to the cosmography and wonder ('ajab).

Containing visual puns, illustrations of toys and games, musical instruments, and teaching and learning, the Miftāh appears to have been made with the intention of delivering a pleasurable education. The combination of its illustrated themes and the large, well-spaced text would have aided readers in mastering these words. This leads me to hypothesize that the Miftāh was an entry-level text that would have primed its readers to understand a range of literary and visual languages. An older member of society, such as a teacher, may have used the work as an object of instruction for pupils. As an initial study of the Miftāh, this article reconstructs the

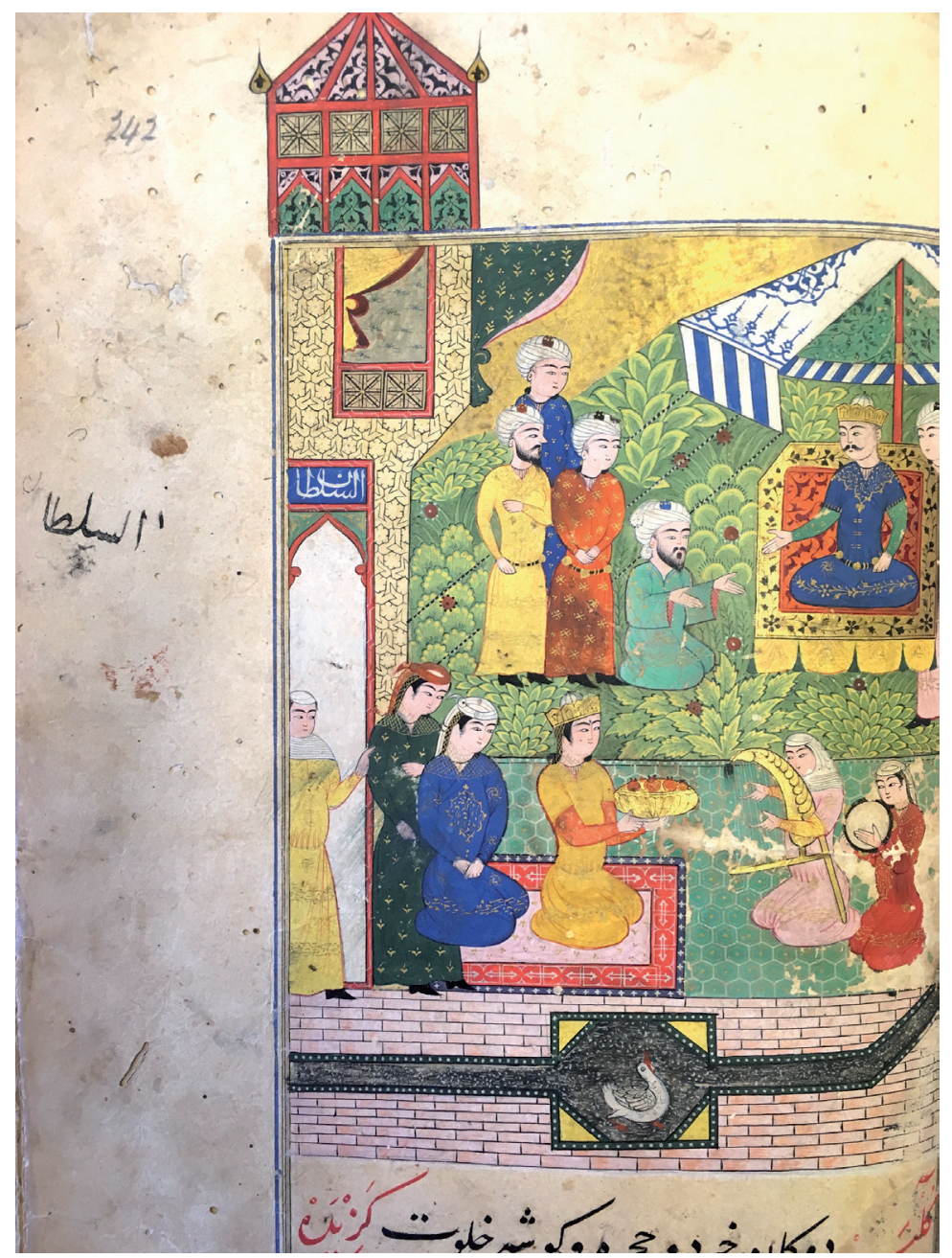

Fig. 1. Pleasure place (kallah) with canopy (kulbah) shown above. Miftāh al-Fużalä’ of Shadiyabadi, Mandu, ca. 149o, 16.2 $\times$ $12 \mathrm{~cm}$ (painted box); $4.7 \times 3.6 \mathrm{~cm}$ (upper canopy), British Library Or 3299, f. 242a. (Photo: Courtesy of the British Library) 


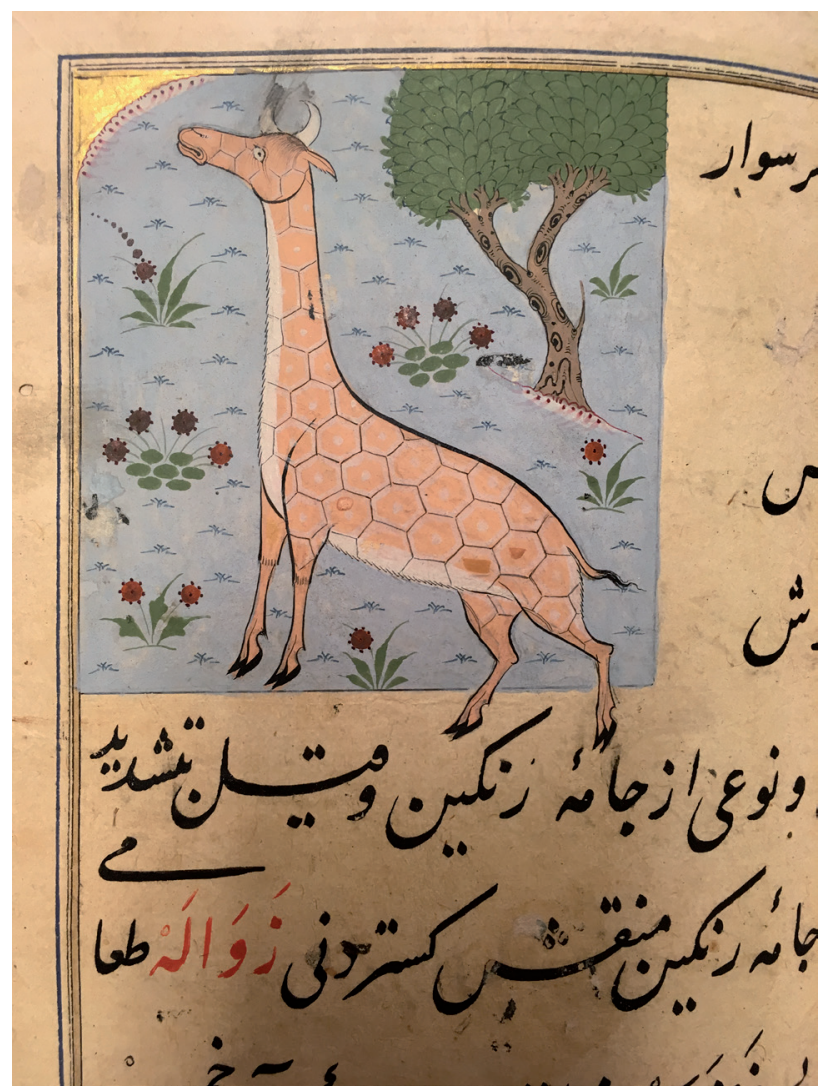

Fig. 2. Giraffe (zarrāfah). Miftāḥ al-Fużală' of Shadiyabadi, Mandu, ca. 1490, $7.7 \times 7.2$ cm, British Library Or 3299, f. 152a. (Photo: Courtesy of the British Library)

history of the manuscript and its context, and appraises its written text and illustrations, laying the foundation for future studies. At the end, I pursue an interpretation of a few illustrations, particularly of crafts, that reveals the significance of wonder for understanding the Miftāh.

\section{HISTORY OF THE MANUSCRIPT}

Although it is cited in most surveys of sultanate arts of the book, the Miftăh has never been the subject of an extended critical study heretofore. ${ }^{10}$ It is addressed in two articles, the first by Norah Titley in 1964-65, and the second by A. Jan Qaisar and Som Prakash Verma in 2002. ${ }^{11}$ In both cases, these scholars adopted a thematic approach to the definitions and focused primarily on the paintings. Titley's initial study of the manuscript estab-

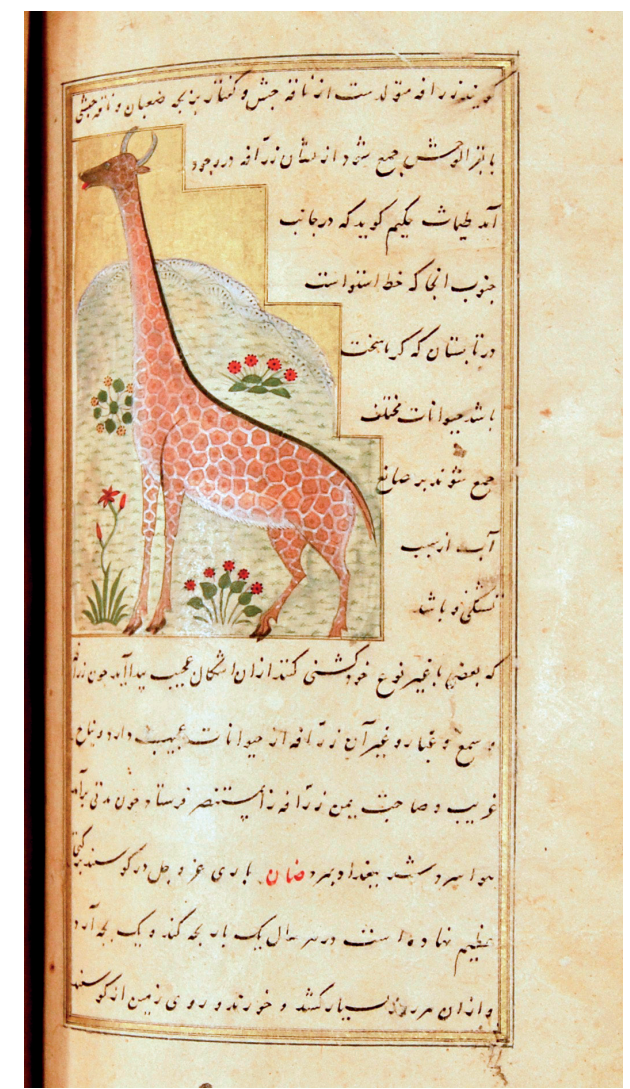

Fig. 3. Giraffe (zarrāfah). Persian Wonders of Creation, Shiraz? ca. 1475, Royal Asiatic Society MS 178, f. 363b. (Photo: Courtesy of the Royal Asiatic Society of Great Britain and Ireland)

lished the following categories of entries: animals; terms for hunting; musical instruments; occupations; trades and crafts; food; costumes; and children's toys. After her publication of Mandu's famed Ni'matnāmah (Book of Delights, ca. 1495-1500), Titley was keen to work on the Miftăh as her next project, yet the only products of that endeavor are her short article and a few handwritten notes. ${ }^{12}$ Dilorom Karomat, whose concerns were textual, examined the presence of the Turki and Hindavi vernaculars in Persian lexicons such as the Miftăh. ${ }^{13}$ At the end of this article, I provide a table of all the illustrations contained in manuscript, having verified these definitions against several lexicons, which I cite where appropriate.

In a preface, Shadiyabadi states that he completed the text in 873 (1468-69), and names the dictionary the Miftāh al-Fuzalä’ ${ }^{14}$ The manuscript of the work in the 


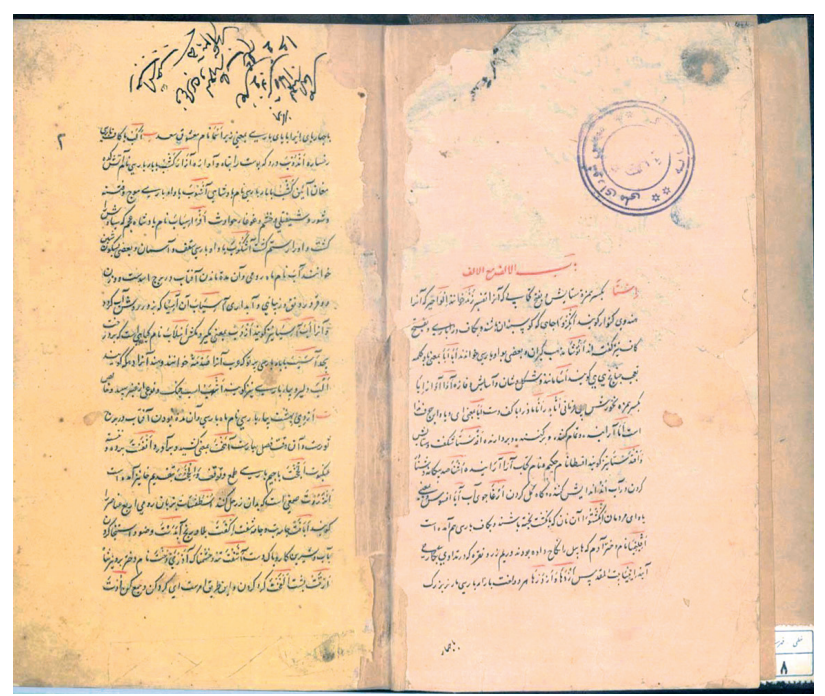

Fig. 4. Preface, Miftāh al-Fużalä' of Shadiyabadi, eighteenth or nineteenth century? Iran or India, Majlis Library, Tehran, IR-10-37320, ff. 2b-3a. (Photo: Courtesy of the Majlis Library)

British Library (BL Or 3299) has been dated to 1490 based on its close similarity to dated Persian manuscripts of this decade. ${ }^{15}$ What occurred in the centuries between the production of the Mifta $h$ and the registration of this manuscript in the British Museum in 1887 is unclear. It appears that the British diplomat Sidney John Alexander Churchill (1862-1921) sold the manuscript to the British Museum in 1886, as the end flyleaf bears the note "Bt. of Sidney Churchill, 10 May 1886." Churchill worked in the Telegraph Department (India Office) from 188 o to 1886 , before embarking on a career in Iran that lasted until $1895{ }^{16}$

Apart from BL Or 3299, an unillustrated manuscript in the Majlis Library in Tehran (IR-10-37320) survives as the only other known extant copy of the Miftāh (fig. 4). Based on a preliminary analysis, this undated manuscript appears to postdate the British Library copy by a few centuries and was likely produced in the eighteenth or nineteenth century. The Tehran copy varies considerably from the British Library manuscript and appears to be a textual exercise of deciphering and editing an older text rather than a book with an explicit didactic aim for its time. The Tehran copy nevertheless allows us to salvage missing folios of BL Or 3299 and clarifies some definitions in cases where there is textual variance. From here onward, when referring to the fifteenth-century
Miftāh, I mean British Library Or 3299, and I refer to the later Majlis IR-10-37320 as the Tehran copy.

\section{THE MIFTĀH IN ITS SULTANATE CONTEXT: ARCHITECTURE AND LEXICOGRAPHY}

The Miftā $h$ was created in the central Indian sultanate of Malwa, a polity that lasted roughly a century (14011531) and boasted many architectural and intellectual achievements. The Afghan governor of Delhi, Dilavar Khan (r. 1401-6), sowed the seeds of the sultanate in Malwa and pursued the Delhi sultanate's conquest of the Paramara kingdom based in Dhar. In a strategic move, Dilavar Khan's son, Hushang Shah (1406-32), shifted Malwa's center to Mandu, also known as Shadiyabad, "The City of Pleasure." Muhammad Khalji (r. 1432-36) overthrew Hushang Shah, and it was during the reign of Muhammad's successor, 'Ala' al-Din Mahmud Shah (1436-69), that the first known manuscripts of Mandu were made. As noted above, the Miftāh was likely created circa 1490, during the reign of the subsequent shah, Ghiyas al-Din (1469-150o). The 'Ajā'ib alSanāi (Wonders of Crafts, British Library Or 13718) was made for Ghiyas al-Din's successor, Nasir al-Din Khalji (r. 1500-1510). ${ }^{17}$

\section{Architecture}

The manuscripts of Mandu were made in an architectural context that linked Delhi to the north and the Deccan to the south. For example, with its iwan-inspired hall and battered walls, an audience hall in Mandu known as the Hindolā Mahal (Swinging Palace, fig. 5), possibly dating from the $133 \mathrm{Os}$, appropriates forms from earlier paradigms established by Delhi's Tughluq sultanate (1320-1414). This architectural vocabulary circulated to capitals further south, as represented by monuments such as the Khüsh Mahal (Happy Palace, ca. 1324-31) in the Tughluq-conquered Kakatiya capital of Warangal/ Sultanpur. ${ }^{18}$ Polychrome ceramic cut-tile revetment ( kāshī kārì) on early fifteenth-century Mandu architecture provides further evidence of the international Timurid style in central India. ${ }^{19}$

Analogous to sultanate architecture, sultanate arts of the book embodied the confluence of an expanding lo- 


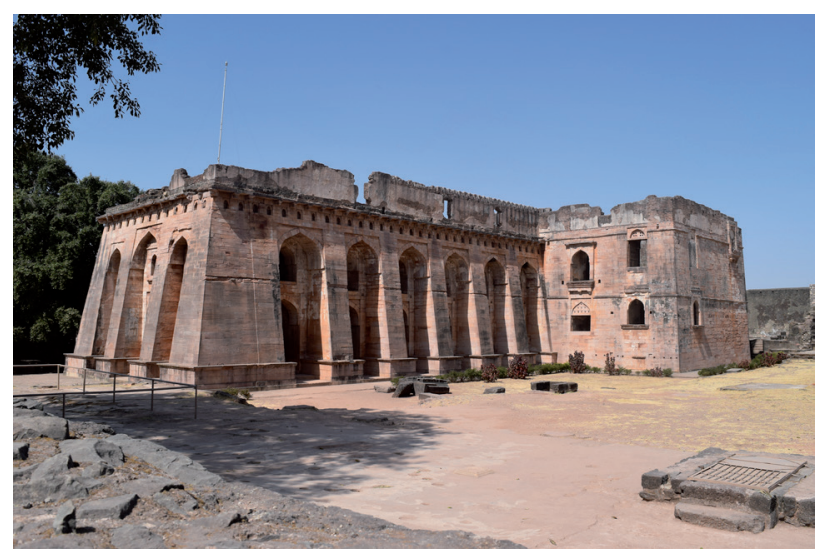

Fig. 5. Hindolā Mahal (Swinging Palace), Mandu (ca. 132431). (Photo: Vivek Gupta, February 2019)

cal idiom with cosmopolitan trends. ${ }^{20}$ Mandu is one of the few early Indian sultanates with a relatively distinct corpus of illustrated manuscripts, but these have yet to be studied as a group. Two Jain Kalpasūtra manuscripts (ca. 1439 and 1470) are among the early works that attest to the production of local artists. ${ }^{21}$ Because both the Ni'matnāmah and the Miftāh contain several Indic words, they also reveal a connection with the local vernacular culture. Yet the presence of the Büstān (1502-3) links Mandu's book culture to the broader terrain of shared Persian cultural practices-the Persian cosmopolis - as do the illustrations of the Miftăh..22

One can also imagine a dynamic school in which Mandu's books were taught. In 'Ali bin Mahmud al-Kirmani Shihab Hakim's Ma'āșir-i Mahmūidshāhī (Traditions of Mahmud Shah, 1468), he describes a madrasa in Mandu, Bām-i Bihisht (Heavenly Vault), and notes the presence of various kinds of decoration on the madrasa's walls that are not extant today: "colored stones such as red carnelian, green, striped, and dark blue jasper, yellow Stone of Mary (sang-i Maryam), white alabaster, black marble, and so forth in the manner that inlaid woodworkers (khätambandān) produce ivory and ebony decoration." ${ }^{23}$ Shihab Hakim writes that artisans (pīshvarān) and possessors of skill (hunarmandān) from the kingdoms of Khurasan (comprising presentday eastern Iran, southern Turkmenistan, and western Afghanistan) and the cities of Hindustan (northern India) were involved in the construction of the madrasa. ${ }^{24}$ In light of this impressive description, the madra-

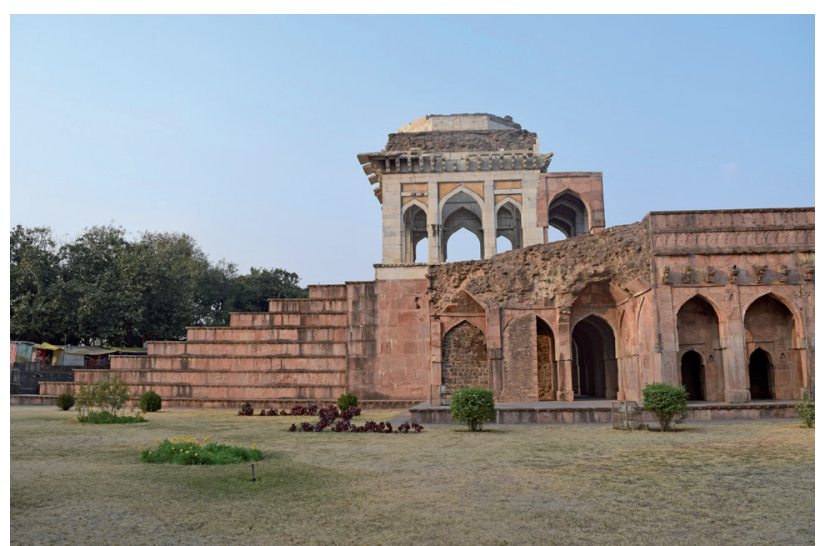

Fig. 6. Madrasah-i Bām-i Bihisht (School of the Heavenly Vault), Mandu, ca. 145o. (Photo: Vivek Gupta, February 2019)

sa was likely built to attract fine scholars from near and far.

Given Shihab Hakim's fulsome praise, the calligraphy decorating the madrasa must have also been a marvel. His description invokes several masters of Islamic calligraphy, and in turn fashions Mandu as a cosmopolitan center:

Persian workers, who are knights in the arena of art, decorated the sides of the lofty dome with tilework ( $k \bar{a} s h \bar{\imath} k \bar{a} r \bar{\imath})$ inscription in thuluth and muhaqqaq scripts of such incredible fineness and straightness that if Yaqut [al-Musta'simi, d. 1296] were not imprisoned in the tomb, he would say that [his own] script was its pupil. And if 'Abd Allah Sirafi were not imprisoned in the dust's house of oblivion, he would have cut his own hand into a pen of envy. Ibn Muqlah [866-939] would have taken each letter from that [inscription] as the kohl of the pen-case of vision. Ibn Bawwab [d. 1022 ] would have known every word as the mirror of interior meaning. ${ }^{25}$

Shihab Hakim's praise has implications for understanding the calligraphy shared by manuscripts and monuments. On its face, this is a conventional literary description of calligraphic practice. But it demonstrates an awareness of the prevailing benchmarks in calligraphic excellence that must have also played a role in the art of the book. Although the madrasa only survives in fragments today (fig. 6), this description reflects achievements in Mandu's manuscript culture. ${ }^{26}$ The madrasa formed a central part of an early fifteenth-century complex of buildings in Mandu that 


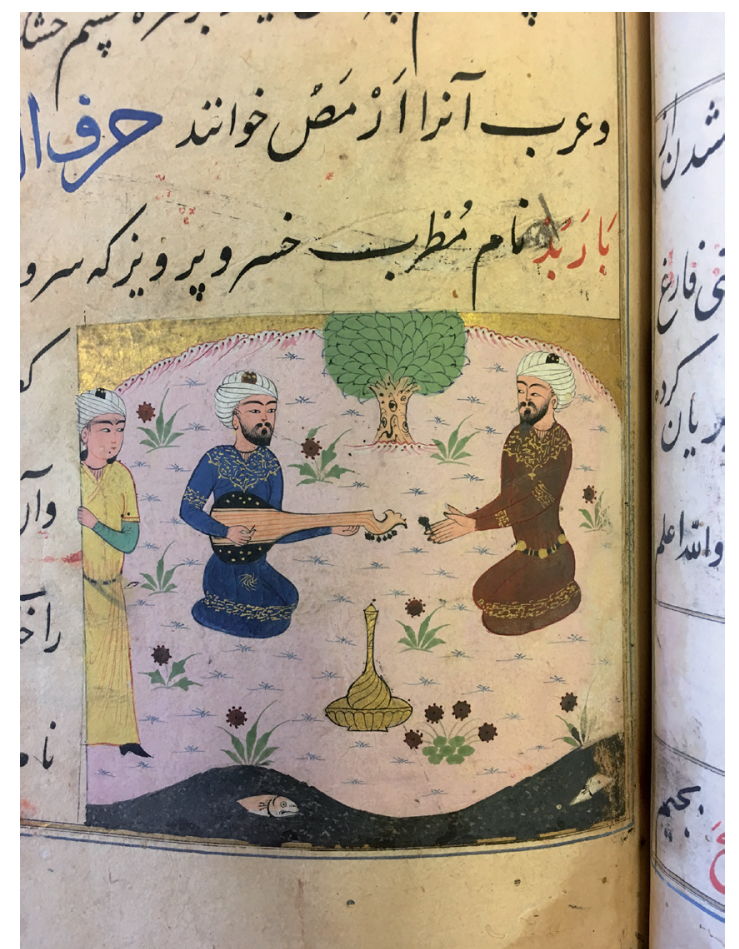

Fig. 7. Khusraw's musician, Barbud. Miftăḥ al-Fużalä' of Shadiyabadi, Mandu, ca. 149o. Painted surface: $8.2 \times 9.3 \mathrm{~cm}$, British Library Or 3299, f. 6oa. (Photo: Courtesy of the British Library)

integrated a congregational mosque and the monumental tomb of Sultan Hushang Shah (r. 1406-35). ${ }^{27}$ As the Miftăh was a wholly original text written in Mandu, the Bam-i Bihisht madrasa would have been an ideal space for Shadiyabadi to study and compile his work. Just as Mandu's Hindolā Mahal displays architectural connections to both north and south, the Bam-i Bihisht madrasa would have participated in intellectual dialogue with other centers from Delhi to the Deccan, and beyond. ${ }^{28}$ Madrasas in neighboring cities include those of Chand$\operatorname{eri}^{29}$ (Malwa) and Bidar (Deccan).

\section{Lexicography}

In contrast with detailed references to architectural commissions, the historical record is comparatively silent about the manuscripts of Mandu. ${ }^{30}$ Shadiyabadi's preface to the Miftăh is only three folios long and conveys few facts about the dictionary. ${ }^{31}$ He classifies the text as a farhangnāmah (lexicon) and states that he uti-

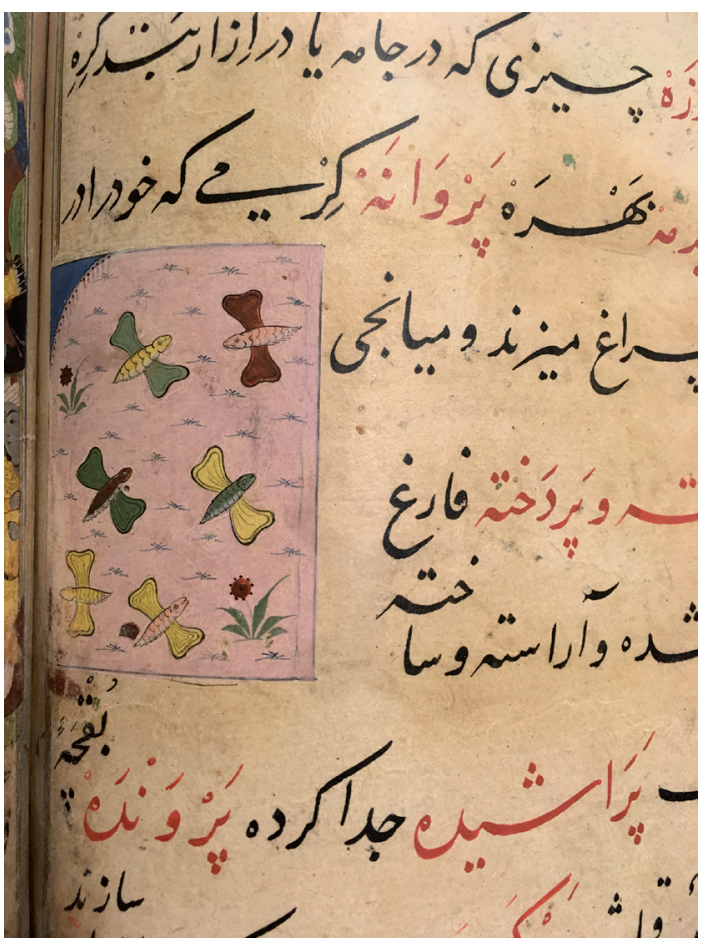

Fig. 8. Moth (parvānah). Miftāh al-Fużalä' of Shadiyabadi, Mandu, ca. 149o. Painted surface: $5.8 \times 4.2 \mathrm{~cm}$, British Library Or 3299, f. 71b. (Photo: Courtesy of the British Library)

lized Pahlavi, Dari, Turki, Hebrew, Greek, and Chaghatai dictionaries. ${ }^{32}$ He also cites the work of Persian poets such as Khaqani, Mu'izzi, Anvari, Nizami, Zahir, Safahani, and Sa'di as inspirations. ${ }^{33}$ Extant copies of Shadiyabadi's commentaries on the oeuvre of Khaqani (d. Tabriz, 1186-99) attest to his close engagement with this poet's work. ${ }^{34}$

Unlike other farhangs of its time, the Miftāh does not quote from poetry. It does, however, illustrate several poetic tropes and figures from the Shähnāmah (Book of Kings) of Firdawsi and from the Khusraw and Shirin romance (fig. 7). ${ }^{35}$ In addition to portraying poetic dramatis personae, the Miftăh gives form to words in Persian poetry that are often used in figurative contexts. For example, the moth (parvānah) that self-immolates in the flame of a candle, symbolizing the lover burning with desire for the beloved, is depicted simply as six fluttering multi-colored moths (fig. 8). ${ }^{36}$ While Shadiyabadi's textual definition describes the moth's attraction to flames, it does not fully explain the allusion to the 


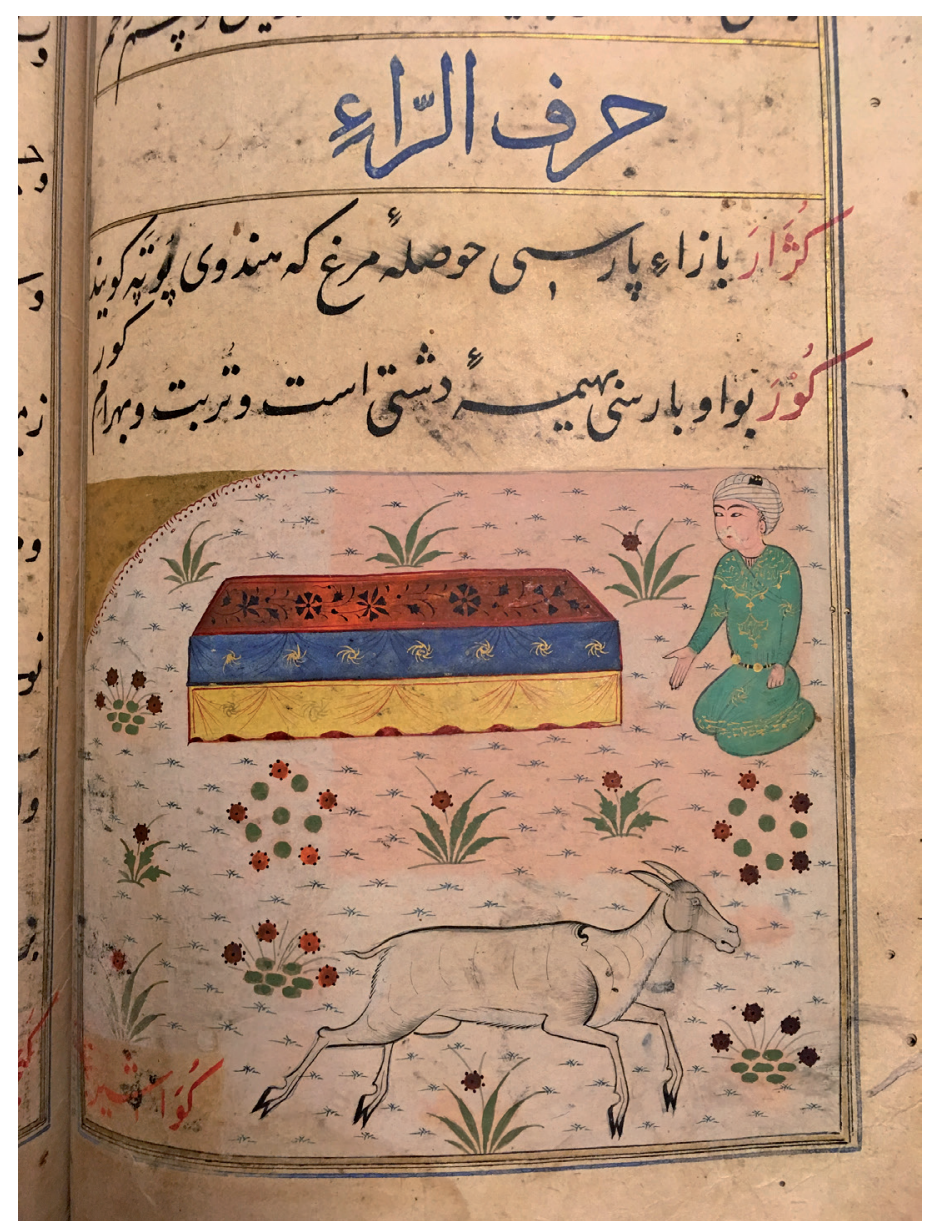

Fig. 9. Wild ass or tomb (gūr). Miftāh al-Fużalä’ of Shadiyabadi, Mandu, ca. 149o. Painted surface: $10 \times 12 \mathrm{~cm}$, British Library Or 3299, f. 248b. (Photo: Courtesy of the British Library)

ubiquitous trope of the lover-beloved. Rather, it allows readers to apply their own literary acumen to deciphering the meaning attached to the moth. The teacher may have pointed to the parvānah and gür and extemporaneously recited a poem containing those tropes.

Shadiyabadi's definition of gūr is another poetic example. He defines gūr as a wild ass, a sepulcher, and part of the name of Bahram-i Gur, the Sasanian king who features prominently in the Shähnāmah (fig. 9). ${ }^{37}$ The accompanying illustration shows a man sitting with arms upturned in front of a textile-covered cenotaph, and an onager in mid-gallop below. This is a literal depiction of two out of the three definitions in the text, if we do not take the seated figure to be Bahram-i Gur himself. The definition, ten words in total, does not explain that gūr is one of the most common words utilized in Classical Persian puns, particularly when it comes to the figure of Bahram-i Gur; ${ }^{38}$ rather, this is left for the new learner to apprehend from other sources.

The illustrated definitions of the gür and parvānah would have struck immediate resonance with any fifteenth-century Persian poet, but Shadiyabadi's redaction of poetic quotations implies that this farhang served purposes other than helping poets choose words with appropriate end-vowels. The definitions of parvānah and gür capture the Miftāh's playfulness, as both rely on the reader to fill in the gaps based on its combination of word and image. The concept of playfulness remains undertheorized within Islamicate contexts, but in the Miftăh, playfulness appears to correspond to a poetics 
of anticipation, similar to how the lover-beloved trope is anticipated from the image of fluttering butterflies. ${ }^{39}$ We can thus envision an elder or tutor (atali $q$ ) using the manuscript as a teaching device, where the images would render lessons easier to comprehend.

The active scholarly environment of Mandu suggests that its intelligentsia and the teachers and students of its madrasa had access to many books. ${ }^{40}$ One indicator of manuscript circulation and production in Mandu are the several sources named by Shadiyabadi in his preface that inscribe the Miftāh within an intellectual genealogy. Shadiyabadi lists the Farhang-i Qavvās (The Lexicon of Qavvas), Risālat al-Nașir (The Treatises of Nasir), ${ }^{41}$ Asadī, ${ }^{42}$ Mafātīh al-Faża $i l$ (The Keys of the Learned), Sulālat al-Fà̇āil (The Genealogies of the Learned), ${ }^{43}$ Dastūr al-Fażāil (The Code of the Learned), and the Lisān al-Shu'arä' (The Tongue of Poets) as his sources. ${ }^{44}$ Three out of these seven works are known medieval Persian dictionaries written in India, two are unidentified, one is no longer extant, and one is of Khurasani provenance.

The first work Shadiyabadi cites, the Farhang-i Qavvās (or Fakhr-i Qavvās), was compiled by the poet Fakhr alDin Mubarak Shah Qavvas Ghaznavi around 1300. ${ }^{45}$ Containing 1,341 entries, it is the first known Persian dictionary completed in India. This citation attests to Shadiyabadi's awareness of the farhang tradition in India that preceded his work by at least a century. In its organization, Farhang-i Qavvās follows the cosmographical tradition, with sections devoted to: (1) celestial creations; (2) earthly creations; (3) plants; (4) animals; and (5) manmade creations. ${ }^{46}$ The fifth section, on manmade creations (dar nām-i chïzhā kih az kār-i àdamī), is full of terminology related to architecture, decorative objects, food, clothing, textiles, and arms and armor. This section remains an unmined treasure trove for historians of medieval and early-modern Islamicate and Indian material culture. ${ }^{47}$ Apropos of the name of this journal, the Miftā $h$ follows the Farhang-i Qavvās in defining the honeycomb vault or muqarnas. ${ }^{48}$ The date of the Farhang-i Qavvās (around 1300) is roughly a century after the emergence of the Persian and Arabic wonders-of-creation illustrated manuscript genre. We can understand this in one of two ways. It either implies a parallel impulse towards codifying these genres (cosmography and farhang). Or, it suggests that Qavvas may have been inspired directly by circulating cosmographies or ideas about the cosmic order.

The second Persian dictionary known to have been composed in India is also included in Shadiyabadi's list. This is the Dastūr al-Fażāail, which was written in Delhi by Hajib-i Khayrat Rafi ' Dihlavi in $1342 .{ }^{49}$ In fact, the Farhang-i Qavvās served as the basis for the Dastūr al-Fà̇ā'il, showing how Shadiyabadi creates a chain of transmission (silsilah). Shadiyabadi's final source, the Lisān al-Shu'arā', is a Persian dictionary that was also composed in India by the author 'Ashiq between $135^{2}$ and 1388 during the time of Firuz Shah Tughluq. ${ }^{50}$

Absent from Shadiyabadi's list is the Farhang- $i$ Zafāngūyā u Jahānpūyā (Dictionary of the Polyglot and World Traveler) completed in 1433 by Badr al-Din Ibrahim in Mandu itself. ${ }^{51}$ Another agent of inter-court relations, Badr al-Din left Jaunpur (located in modernday Uttar Pradesh, northern India) in 1409 or 1419 for the patronage of Dilavar Khan in Malwa. ${ }^{2}$ Although the Farhang-i Zafāngūyā was an authoritative example of lexicography (according to Solomon Baevskiú), it either did not impress Shadiyabadi enough to cite it in his preface, or he may have never consulted it. ${ }^{53}$ One possible reason for Shadiyabadi's omission of the Farhang-i Zafāngūyā is its philosophical difference from the Farhang-i Qavvās. While the Farhang-i Qavvās is organized according to God's creations, the seven parts of the Farhang-i Zafāngūyā are ordered etymologically; the first four parts are devoted to Arabic, Aramaic, Greek, and Turkish, and the last three parts are divided according to Persian simple words, complex words, and infinitives. ${ }^{54}$ The Farhang-i Zafāngūyā surely served as a practical dictionary for poets, whereas the Farhang-i Qavvās and the Miftāh concentrate on broader, cosmographic knowledge. This is not to say that poets did not think cosmographically when seeking words to fit their end-rhymes. It is entirely possible that poets searched for words based on their celestial or worldly meanings and could easily find the desired rhyming syllable within these themes. Nevertheless, the number of definitions Shadiyabadi lifts verbatim from the Farhang-i Qavvās shows his appreciation of the work. While the Farhang-i Zafāngūyā may have been avail- 
able to Shadiyabadi, he clearly preferred the farhang that spotlighted the wonders of God's creation, the Farhang-i Qavvās. And yet, for the makers of the Miftāh manuscript, theirsourceswere not only textual. They were poetic images, several of which carried multiple allusive meanings.

Whether or not Shadiyabadi read Persian encyclopedias in Mandu itself is unknown. He could have traveled to the libraries in Jaunpur, Delhi, Bidar, or Gwalior to access these books. Shadiyabadi's name suggests that he was from Shadiyabad/Mandu or at least was descended from a lineage attached to the city. Considering that two extraordinary lexica, the Farhang-i Zafāngūyā u Jahānpūya and the Miftāh, were produced in Malwa, it is safe to assume that Mandu's libraries were stocked with abundant intellectual resources.

In addition to the Farhang-i Zafängūyà u Jahānpūyā, another noteworthy absence from Shadiyabadi's sources is any Hindavi source text. It is likely that Hindavi sources would have been filtered through other Persian dictionaries produced in India, supporting what Stefano Pellò has designated as the "provincialization of Persian" in fifteenth-century Persian lexicography. ${ }^{55}$ Indeed, Persian farhangs written in India negotiated the cosmopolitanism and vernacularization of Persian in India.

The Miftāh itself attests to the existence and knowledge of many other books in fifteenth-century Mandu. One book serves as an index of many more. In other words, the production of farhangs in Mandu suggests the presence of particular books that would have been read and written with the aid of these farhangs. Given the Miftă $h$ 's linguistic diversity, one can imagine that many scientific texts and works of belles-lettres in Arabic, Persian, Turkish, and Indic languages were composed in Mandu. The Miftāh would have allowed readers to enjoy a range of texts written in these languages, and to create new works using a rich vocabulary. The Miftāh is thus critical to reconstructing the contours of the manuscripts that may have circulated in fifteenth-century India. What is now just a few dispersed fragments can transform into a full-fledged library of the sultanate arts of the book by investigating the associations of each entry in this dictionary. Skelton's searing insight about the significance of the Miftāh's allusions thus acquires further power.

\section{THE FORM OF THE MIFTĀH: WRITTEN TEXT AND STYLE OF ILLUSTRATIONS}

\section{The Written Text}

The calligraphers who inscribed the Miftāh must have been allowed some degree of agency in determining a suitable design for an illustrated farhang. As far as we know, this was a textual genre that had never before been copied with such resources. The 'unvān (headpiece) of the Miftāh is executed in black and blue inks, with gold and silver, and its pattern is dominated by split palmettes (fig. 10). Its ruling (inner to outer) consists of five lines of black, thick gold, black, black, and lapis. Organized alphabetically, the manuscript's chapter $(b \bar{a} b)$ headings are mostly inscribed in a thick gold naskh script, sometimes with black outlines. These are occasionally placed within a gold and black-ruled text box (fig. 11). The end-letter (harf) of the lemma further subdivides the $b \bar{a} b .{ }^{56}$ The harf headings are written in thick blue naskh script similar to the $b \bar{a} b s$ (fig. 12). Like a modern-day tab for a filing folder or binder, the corresponding letter of chapter headings helpfully appear in matching ink and script in the manuscript's outer margin. ${ }^{57}$ This is a practice that also occurs in Mandu's Nimatnämah. For the harf headings, the corresponding letter is placed in its adjacent marginal area like the bābs. Of the 394 total harf headings, ${ }^{58} 24$ either lack complete text boxes or do not have them at all. The tabs in the margins are still legible in most cases.

The logic and clarity of the Miftăh's paleography further emphasize its didactic purpose. The fact that its Hindavi words are sensitively rendered in nasta lì $q$ with adjusted lettering allows readers to pronounce these words correctly. To my knowledge, such adjustments were not made for sounds unique to Chaghatai. Unlike the relatively close affiliation between the syllabaries of Arabic and Persian, Hindi and Sanskrit contain a number of sounds that are absent from Arabic and Persian. In the Miftāh, short vowels and diacritics (harakät) are only utilized for the lemmas in red and for the corresponding Hindavi word in black if it is given. In two definitions of toys, the scribe found solutions for several non-Perso-Arabic sounds. The presence of Hindavi equivalents in the definitions for hobbyhorse and spinning top is likely because such toys were part of the 


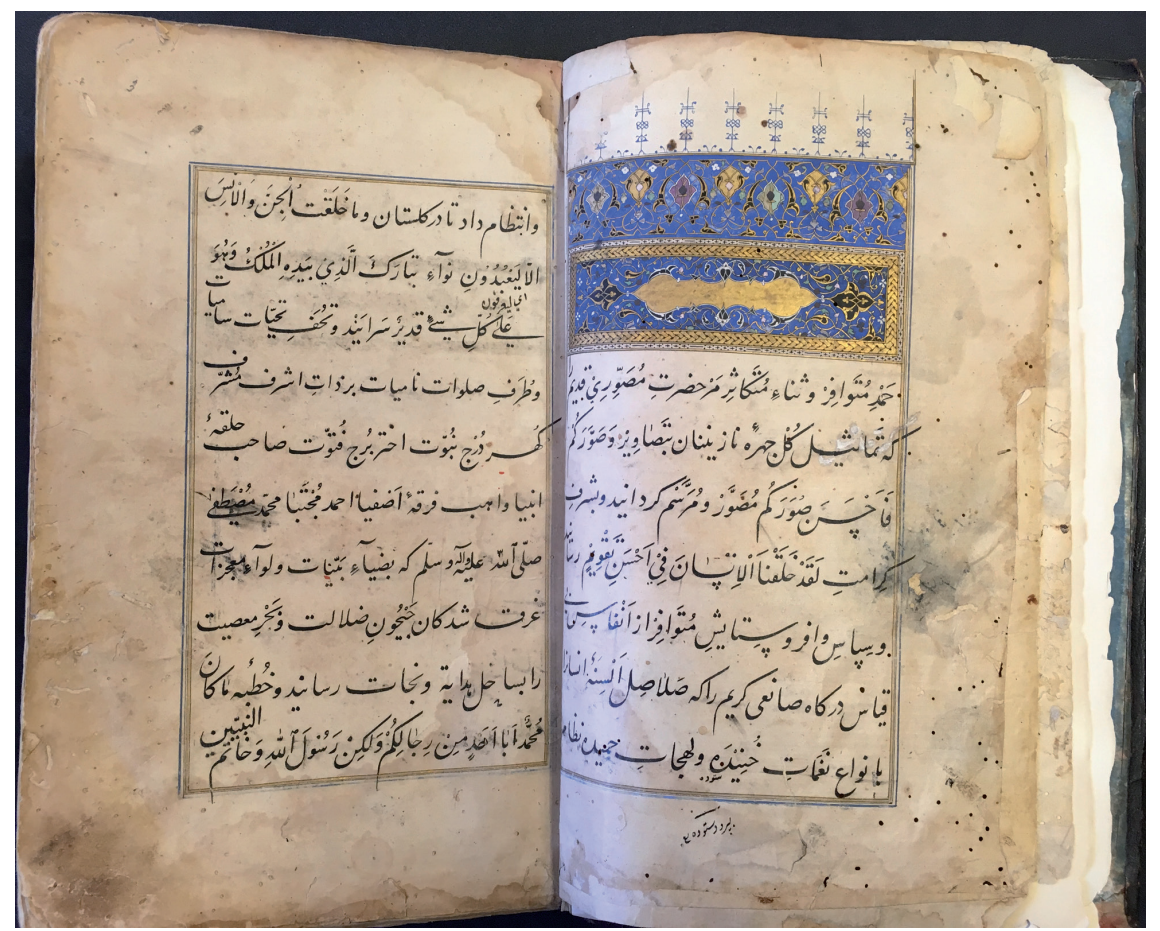

Fig. 10. Headpiece ('unvān). Miftāh al-Fużalā' of Shadiyabadi, Mandu, ca. 149o. Folio: $33 \times 25.4$ cm, British Library Or 3299, ff. 2b-3a. (Photo: Courtesy of the British Library)

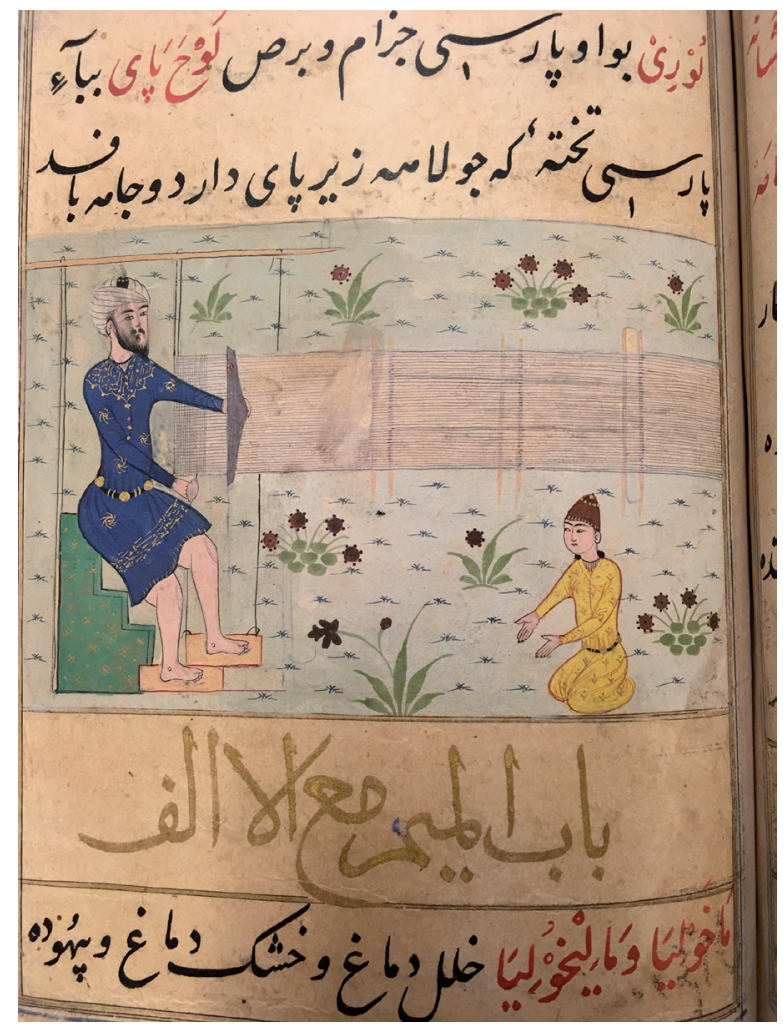

Fig. 11. Bāb al-Mìm ma' al-Alif, illustration: footboard or treadle for a loom (lawh-i pāy). Miftāh al-Fużalā' of Shadiyabadi, Mandu, ca. 149o. Painted surface: $8 \times 12 \mathrm{~cm}$, British Library Or 3299, f. 262a. (Photo: Courtesy of the British Library) 


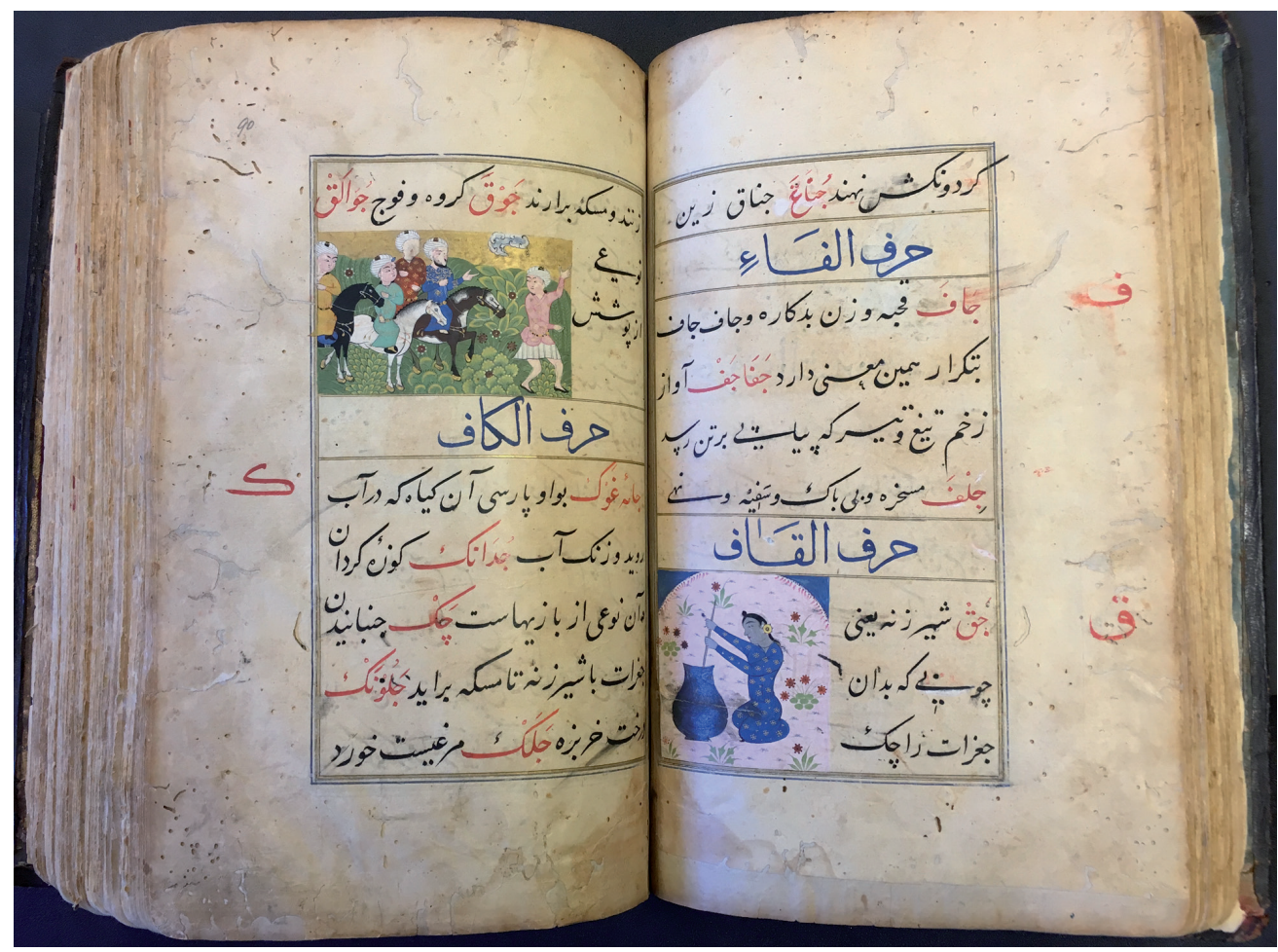

Fig. 12. Right folio 89b: Harfal-Fä', Harfal-Q̄äf, illustration of jaq, "to churn." Left folio goa: illustration, group of an army, jüq; Harf al-Käf, tabulating letters shown in outer margins. Miftāh al-Fü̇alä’ of Shadiyabadi, Mandu, ca. 149o. Folio: $33 \times$ $25.4 \mathrm{~cm}$, British Library Or 3299, ff. 89b-9oa. (Photo: Courtesy of the British Library)

vernacular, everyday life of children. With regard to the hobbyhorse or kürasht, the scribe adapts the retroflex $\underset{d}{d}$ by applying three dots below the $d \bar{a} l$ in the Hindi word dand̄a-mūhì (stick-face) (fig. 13). ${ }^{59}$ Three dots are not utilized for these particular letters in Persian or Arabic scripts; rather, this is an adjustment used to signal a letter foreign to the script.

Another example of how the scribe made an adjustment in Persian for an Indic syllable-and likely heard its doubling - is the doubled retroflex syllable in the Hindavi word latt $\bar{u}$, which denotes a spinning top. This word appears in the Persian illustrated entry for farmūk, "top" (fig. 14). ${ }^{60}$ The scribe identified the doubled ța retroflex syllable by means of three dots below the PersoArabic $t \bar{a}$. The scribe found a creative analogue for the doubled syllable with the application of a shaddah over the letter. For the synonymous non-illustrated Persian word pahnah, which is also included in the lexicon, the three dots that had previously indicated a retroflex syllable in the word latțu inexplicably do not appear. ${ }^{61}$ The inconsistency lies primarily in the number of dots. For the illustrated farmūk, Shadiyabadi specifies that latțu (inscribed with three dots) is how the word is said (güyand) in Hindavi, whereas for the non-illustrated pahnah, he states that latt $\bar{u}$ (without dots) is how the people of Hind (ahl-i Hind) read or recite it (khvānand). This inconsistency suggests that the representation of Indic retroflex syllables in nasta lì $q$ was not a standard scribal practice. That the Hindavi words are given any special attention at all further supports Karomat's argument that the Mifta h functioned as a Hindavi manual for Persian readers. In the absence of any text that clarifies Hindavi sounds for the Persian reader, a teacher may have had to explain to the new learner why the word lattū was inscribed with three dots.

The inclusion of Hindavi words in the Miftāh represents a rare case of early Hindavi in nasta lìq. In particular, it differs from how the words are written in Mandu's Nimatnammah and the genre of the Hindavi Chāndāyan. Since the Nimatnāmah is a book of recipes with 


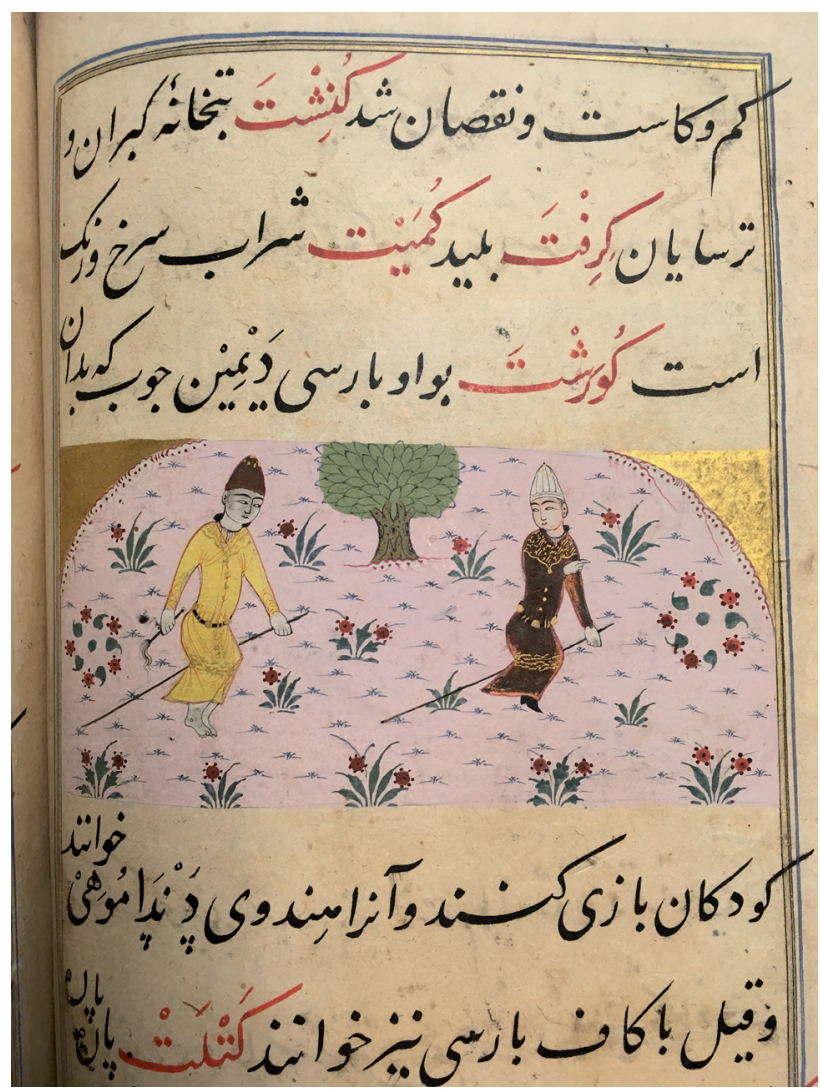

Fig. 13. Hobbyhorse (kūrasht, danḍ̄a-mūhū). Miftāḥ al-Fużalà of Shadiyabadi, Mandu, ca. 149o, Painted surface: $5.7 \times 12 \mathrm{~cm}$, BL Or 3299, f. 22ob. (Photo: Courtesy of the British Library)

instructions on how to prepare the sultan Nasir al-Din Shah's favorite dishes and other pleasures, its Persian is peppered with many colloquial Hindavi words such as those for local ingredients. ${ }^{62}$ In this case, the scribe deemed it worthwhile to apply diacritics and short vowels to all words in the text regardless of language. The Nimatnämah is written in black naskh (red headings) with large swooping nün ligatures and dramatically elongated kāfletters (fig. 16). ${ }^{63}$ These kinds of $n \bar{u} n$ s and $k \bar{a} f \mathrm{~s}$ are typical of the sultanate Bihārī script and its miniaturized form of naskhi-dīvannī, but this script overall is clearly closer to naskh. The presence of these features in the Ni'matnämah suggests the scribe's possible mastery of these other scripts. ${ }^{64}$ In contrast to the Nimatnāmah, the sultanate manuscripts of the Hindavi Chāndāyan, which are sometimes written in a naskhī-dīvānì script, use harakāt or diacritics sparingly. ${ }^{65}$ The notable ab-

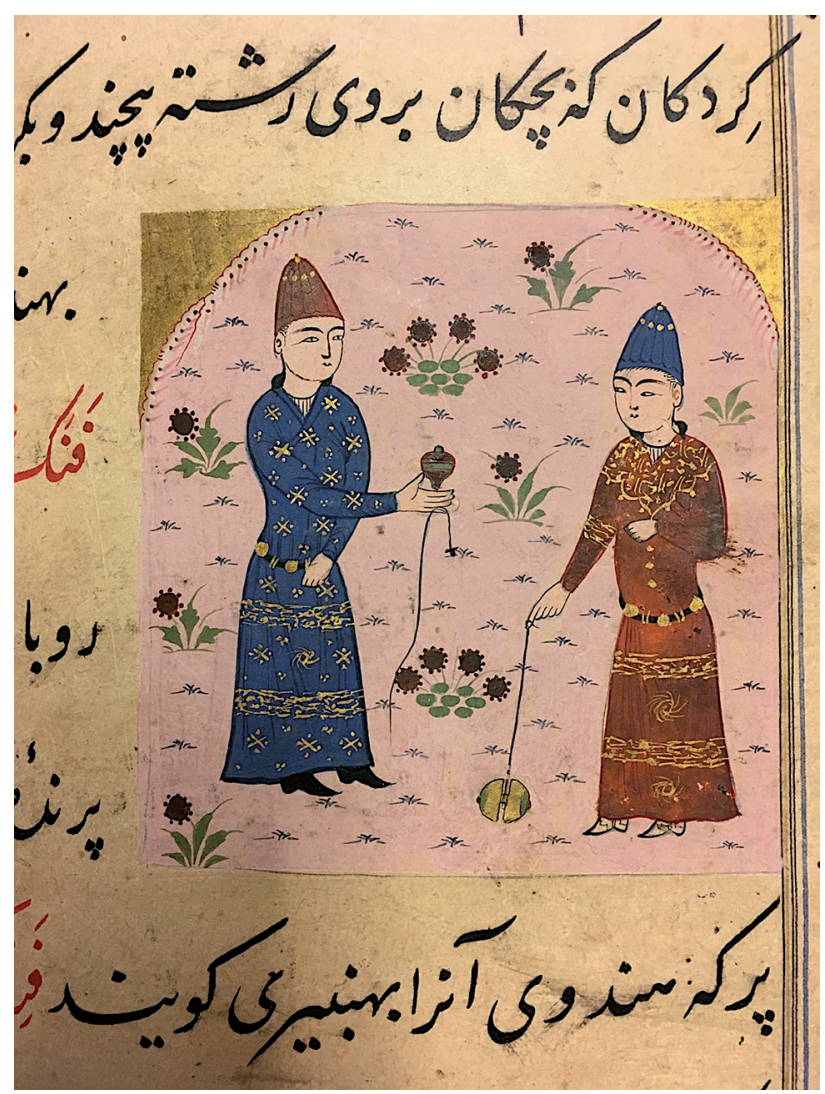

Fig. 14. Yo-yo (farmūk, lațtū). Miftāḥ al-Fużalā' of Shadiyabadi, Mandu, ca. 149o. Painted surface: $7.6 \times 7.6 \mathrm{~cm}$, BL Or 3299 , f. 212a. (Photo: Courtesy of the British Library)

sence of harakāt, even for the Hindavi words within the Persian headings of the Chändāyan manuscripts, implies that readers would have inferred these vowels with little guidance. As the poetry of the Chändāyan is in metered rhymed verse, short vowels in the naskhi-dīvāni would have been quite useful: their absence presumes a knowing reader, or a reading context of oral recitation. This variety of strategies for inscribing Hindavi words in Perso-Arabic scripts in the sultanate context suggests a diversity of audiences for this vernacular languagefrom the new learners of the Miftāh to the poetry connoisseurs (rasikas) enjoying the Chāndāyan.

An appraisal of the text's contents also reveals that it does not survive in its original form. Of the 22 total chapters in the Miftāh, the final two chapter headings for the letters $h \bar{a}^{\prime}$ and $y \bar{a}^{\prime}$ are missing. The first missing $b \bar{a} b$ heading is between folios $295 \mathrm{~b}$ and $296 \mathrm{a}$, and the second 
is between folios $301 \mathrm{~b}$ and $302 \mathrm{a}$. Between folios $295 \mathrm{~b}$ and $296 \mathrm{a}$, it is possible that the original text jumped from the final section of Harfal-Hā’ to Jìm-i Pārsì (The Persian jīm, or cha sound). If this is true, then there would be no losses between these two folios. However, in the second case, a lack of correspondence between the catchword on folio $301 \mathrm{~b}(b i-v \bar{a} v)$ and the first word of folio $302 \mathrm{a}(\mathrm{ku}$ nad) implies a loss of folios.

Textual evidence also suggests that the manuscript suffered losses. In his preface, Shadiyabadi states that "twenty-two chapters were arranged after [this lexicon] was composed and accepted" (va bist $u$ du bāb ittifāq uftād ba'd-i malhūz u manzūr shudan). ${ }^{66}$ It is unclear whether this phrase refers to his text in general, or to Or 3299 as a manuscript. Although the later Tehran manuscript differs from the much earlier Miftăh in its ordering and language, it preserves several entries that would have been located on the missing folios of $B \bar{a} b-i$ Jìm-i Pārsĭ. ${ }^{67}$ In other words, there are clearly some missing folios in the British Library's Miftāh, but whether or not Shadiyabadi was present to witness these problems in two chapters of the manuscript remains an open question. The folios could have gone missing if the manuscript's quires of quaternions were ever unbound from its current leather binding. Because of the high ratio of illustrations to folios (179:306), the fact that some pages have been lost allows us to hypothesize that certain unknown illustrations are also missing from the manuscript.

\section{Style of Illustrations}

The Miftăh's illustrations closely relate to the Turkmen painting practice. ${ }^{68}$ In the latter half of the fifteenth century, the main center of this style was the southwestern Iranian city of Shiraz. The spread of the Aq Qoyunlu Dynasty (White Sheep Turkmens) to areas in western Iran, eastern Anatolia, and Iraq led to the establishment of new sites for the mass production of Turkmen manuscripts. ${ }^{69} \mathrm{~B}$. W. Robinson describes this style as follows: "the figures are stocky and child-like, and the background is either pale with small tufts or lush green with large masses of vegetation."70 The paintings of the Miftăh make clear that this style was practiced in India as well. Yet we will likely never know if the painters responsible for the Miftăh were trained in this style in In- dia, Iran, or elsewhere before the Miftạh was made in Mandu. ${ }^{71}$

A comparison with Shirazi paintings in dated manuscripts brings the Miftāh 's paintings into sharper focus. A close Shirazi counterpart to the Miftāh is a manuscript of 'Attar's Mantiq al-Tayr (Conference of the Birds) made in $1493 .{ }^{72}$ An opening illustration shows the mythical bird, the simurgh, supervising all of the other vibrantly feathered birds in a dense green thicket (fig. 15). The artist rendered the shrubbery by painting thin strokes of a dense verdigris base and adding lighter, more dilute green and yellow highlights above. Circular gold flowers in clusters are placed above the greenery. This pattern of thicket is widely used in at least two of the known Mandu manuscripts, the Miftāh and the Ni'matnämah (fig. 16). ${ }^{73}$ The second element of the Miftāh that closely resembles a Shirazi painting practice is an arrangement of green plants against a pale blue ground. ${ }^{74}$ The manuscript isolates these plants in its illustration of jullah, "plants / mushrooms" (fig. 17$).{ }^{75}$ This unique example suggests that artists may have had a specific plant in mind when painting the common decorative feature. A Shāhnāmah made in Shiraz one year after the Mantiq al-Tayr in 1494 shows a similar plant: in the scene of Isfandiyar being interviewed before his father, the hill is painted in a pale blue ground with interspersed flowering plants (fig. 18) ${ }^{76}$ This image uses the two main background elements of Turkmen paintings. The skies in these paintings are also often executed in gold with a semi-circular horizon line. ${ }^{77}$

The connections between Shirazi and sultanate manuscript cultures transcend the features of this painting style. It is well established that over the course of the fifteenth century, that the arts of the book in sultanate India witnessed several archaisms. Éloïse Brac de la Perrière has demonstrated how one of the clearest inspirations was from fourteenth-century Injuid manuscripts from southern Iran. ${ }^{78}$ The intertwined careers of Iranian intellectuals indicate the longstanding networks in which artists participated and in which books played a major role. For example, Jalal al-Din Davani, a fifteenth-century Shirazi intellectual, never migrated to India, but in 1468 he dedicated one of his works to the Bahmani governor Mahmud Gavan (d.1481) of Bidar and gifted another text to the sultan Mahmud Begarh of Gujarat (r. 1458-1511). ${ }^{79}$ Considering the migration trends 


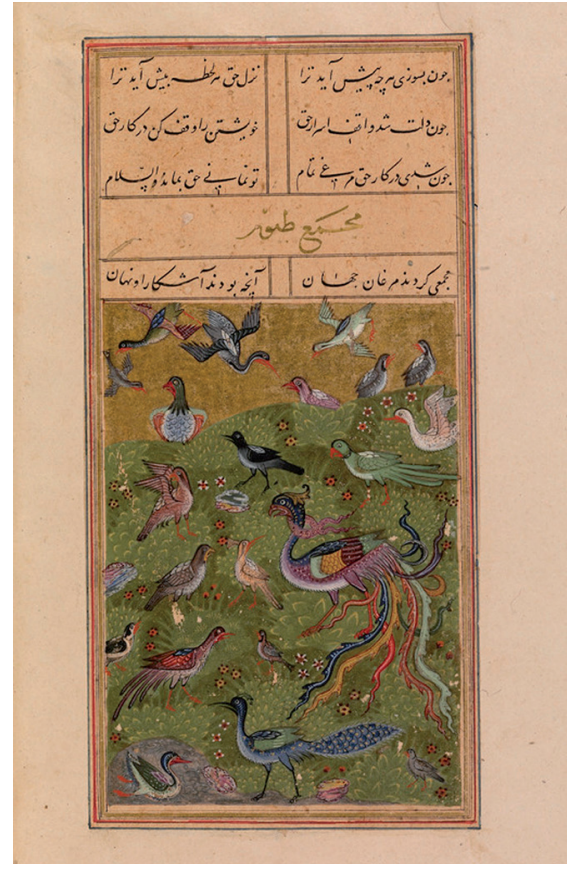

Fig. 15. The conference of the birds presided over by the simurgh, Manțiq al-Țayr (Conference of the Birds) of 'Attar (1145-1220), Shiraz, 1493. Folio: $10.4 \times 7.3 \mathrm{~cm}$, Bodleian Library MS Elliot 246, f. 25b.

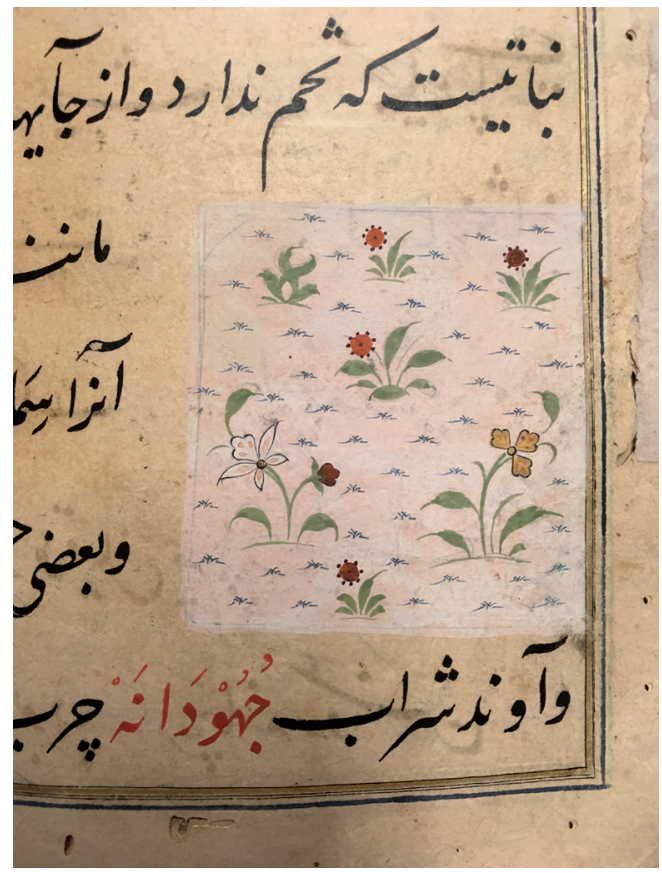

Fig. 17. Plant, mushroom (jullah). Miftāh al-Fużalāco of Shadiyabadi, Mandu, ca. 149o. Painted surface: $5.7 \times 5.3 \mathrm{~cm}$, British Library Or 3299, f. 92b. (Photo: Courtesy of the British Library)

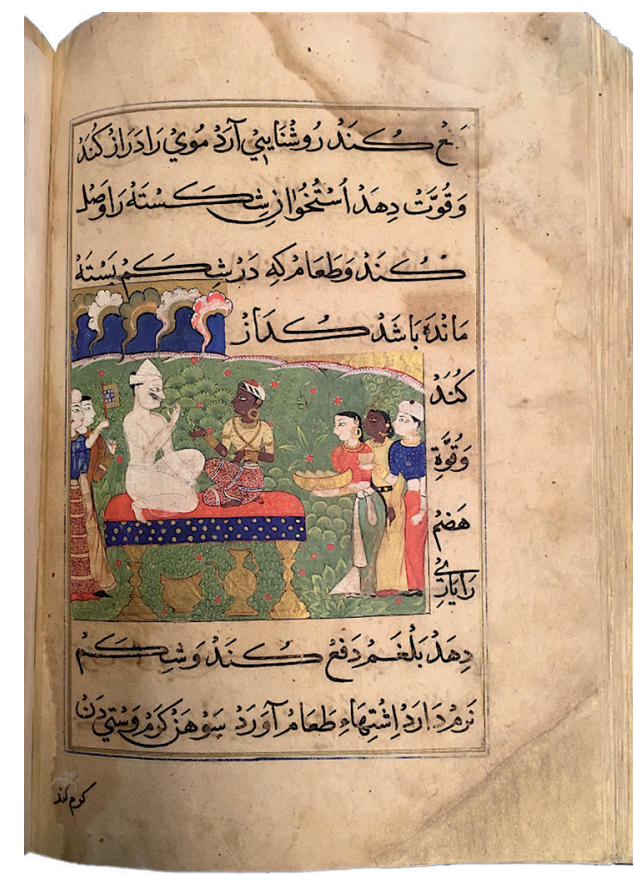

Fig. 16. Ghiyas al-Din eats betel, Ni'matnāmah (Book of Delights); artist: Haji Mahmud; scribe: Shahsavar al-Katib, Mandu, ca. 1490-150o. Folio: $20.5 \times 14$ cm, BL IO Islamic 149, f. 10ob.

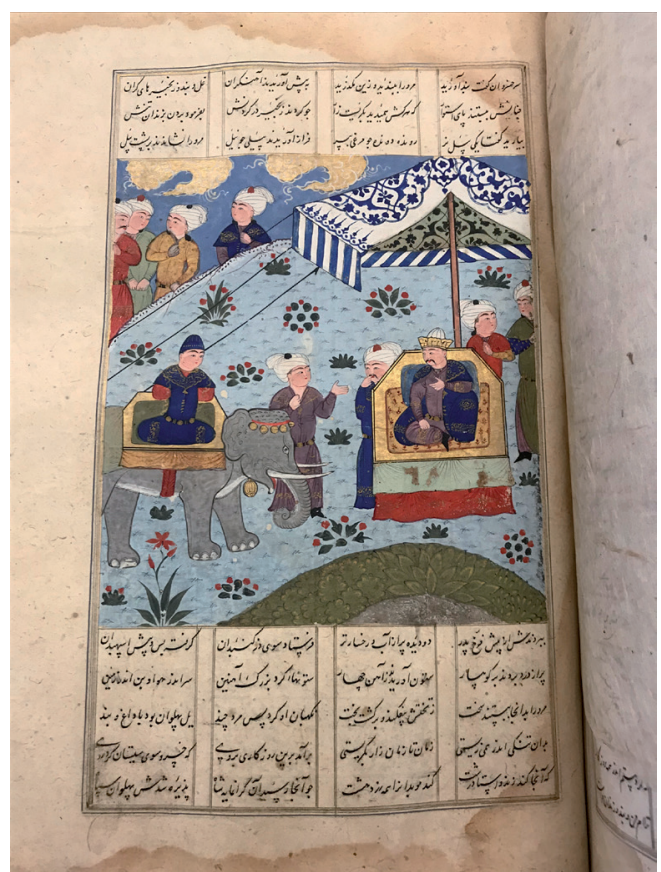

Fig. 18. Isfandiyar interviewed before his father Gushtasp, Shāhnāmah of Firdawsi, Shiraz, 1494. Folio: $13.9 \times 12.7 \mathrm{~cm}$, Bodleian Library MS Elliot 325, f. 328a. 
of artists and intellectuals in tandem strengthens our knowledge of cultural flows during the fifteenth century. ${ }^{80}$ It is probable that many artists from this period were like Jalal al-Din Davani: they may have maintained relations with patrons based in South Asia but never left their homes in Iran. In cases such as the Miftāh, it is best to think of Shirazi and sultanate manuscript cultures as part of the shared cosmopolitan Persian ecumene. ${ }^{81}$

\section{THE FUNCTION OF THE MIFTĀH: AN ENTRY-LEVEL TEXT FOR NEW STUDENTS}

A close look at the Miftăh reveals the possible function of the manuscript as an entry-level text for teaching new or young students. If we had only the Tehran manuscript and not the British Library copy, it would be impossible to suggest this. However, the preponderance of illustrations in the Miftāh that depict learning or allude to play and upbringing allows us to think of it as a book for instructing new learners. The clear and well-spaced calligraphy coupled with the fact that lexica were, by their very nature, consultative books used to teach the mean-

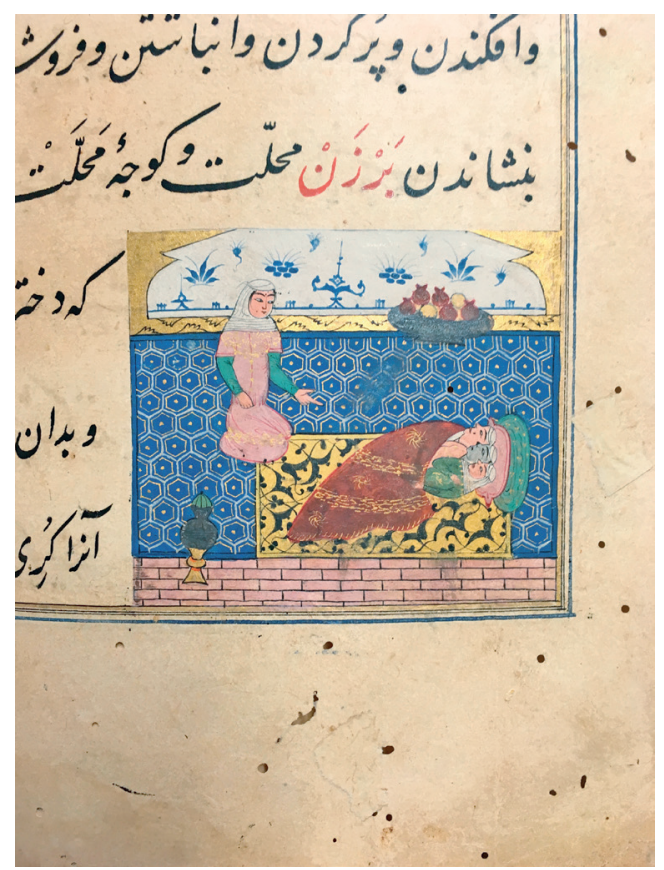

Fig. 19. Dolls (bādajan). Miftāḥ al-Fużalä' of Shadiyabadi, Mandu, ca. 149o. Painted surface: $5.9 \times 6.8 \mathrm{~cm}$, BL Or 3299, f. 51 b. (Photo: Courtesy of the British Library) ings of new words inform my view that the manuscript was specifically intended for a young member of society or someone responsible for cultivating youth, such as a tutor. ${ }^{82}$ Although we lack a social history of early development or upbringing in the Indo-Islamicate world, I hope that the preliminary analysis below will serve as a gateway for further work on this important and neglected topic. ${ }^{83}$

Illustrations germane to a younger age group include images of figures playing with toys. The Miftăh contains two illustrated definitions of dolls, two yo-yos, one spinning top, a hobbyhorse, and a swing (figs. 13,14$).{ }^{84}$ While such pleasures are not necessarily exclusive to youth, the dolls are rather explicit examples. In the illustrated definition of bādajan ("dolls"), we see a young girl putting her three dolls to bed on a carpet (fig. 19). The definition of lahfatān, a synonym for dolls, multiplies the illustration of the bādajan, showing two veiled girls putting their male and female dolls to bed on a carpet and pillow (fig. 20). ${ }^{85}$ We can imagine these illustrations being used to teach young learners the names of playthings. Adults can appreciate these illustrated definitions of toys as well, but their peculiar recurrences in the

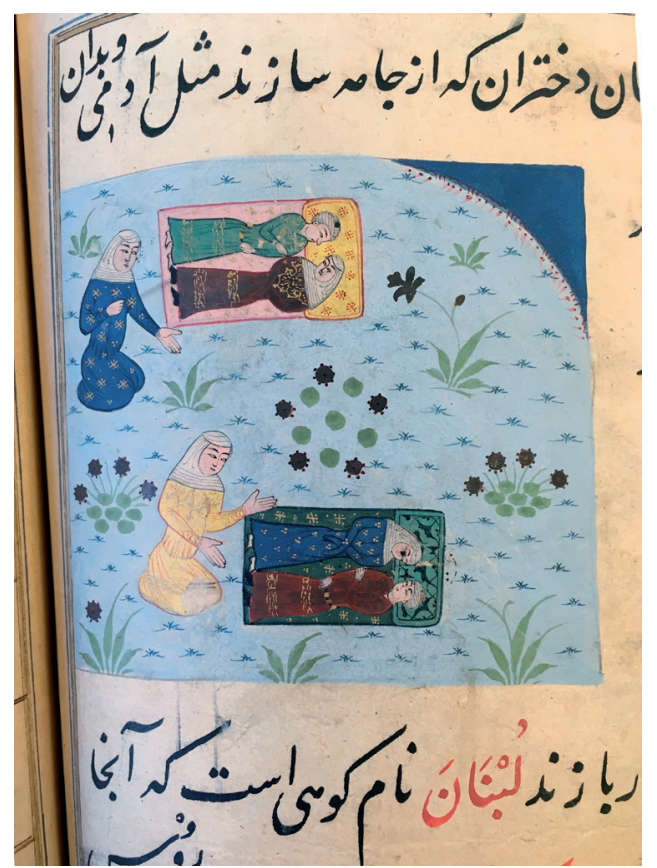

Fig. 20. Dolls (luhfatān). Miftāh al-Fu̇̇alä' of Shadiyabadi, Mandu, ca. 149o. Painted surface: $7.5 \times 8 \mathrm{~cm}$, BL Or 3299 , f. 259b. (Photo: Courtesy of the British Library) 
Miftăh raises the important question of the manuscript's intended audience.

In addition to the toys featured in the Miftăh, it is fruitful to pursue a close reading of one example of early didacticism depicted in the work and its resonances throughout the Miftăh. The primary entry of concern is that of the new student, or naw āmūz. Shadiyabadi provides the following definition: "The New Student: with two Persian letter $v \bar{a} v$ s; a youth (küdakī) whose education begins at school; and a leopard or hunting bird that is fed with $b \bar{a} v \bar{v} l \bar{l}$ to learn hunting" (naw āmūz: $b i-v \bar{a} v-i$ duvvum-i bārsī; kūdakī kih ānrā āghāz dar dabistān andākhtah bāshand; va yūz va shikarah kih ānrā ibtidā bāvulì dihand). ${ }^{86}$ Illustrations appear above and below this text (fig. 21). Above, a herd of six young goats follows a leader through a thicket; and below, a class is underway. A teacher instructs from a gold pulpit and gazes towards his six students seated on the ground. ${ }^{87}$ The new students read from their tablets and books. Within the painting, the students' text is none other than the definition in the manuscript itself, which makes the illustration a mise en abyme and characterizes the classroom as a suitable space for reading the Miftāh. The two students, one female and the other male, in front of the teacher may depict royal youth, as the male wears a small crown on his head.

Apart from this definition of the new student, one finds many other entries in the Miftăh that establish the parallelism between animal and human upbringing and development. From the animal kingdom, the reader encounters a range of dictionary entries defining infant animals that resonate with the young goats following their leader. The Miftā $h$ provides two illustrated definitions of baby chicks, a tame ram used for children, and a foal. ${ }^{88}$ From the human world, the Miftăh illustrates several images pertaining specifically to children. It shows the gift given to a child after finishing the Qur'an. ${ }^{89}$ We might think of this as the reward children receive after they graduate from primary school. The Miftāh also devotes illustrated definitions to $z \bar{a} d$, "son," and the mixed language of a child, or kazhmazh (fig. 22). ${ }^{90}$ In the illustration of kazhmazh, an onomatopoetic word, a woman, probably the mother, speaks to her son, who is comparatively much smaller.

In concert with the full-page definition of the new student, the preponderance of definitions that empha- size upbringing and are deemed worthy of an accompanying illustration provides some evidence as to how the Miftăh was intended to teach. On its own, the illustrated definition of the new student offers a visual analogy that clarifies the meaning of the word naw a $\bar{a} \bar{u} z$. But when taken together with all the other images of animal and human education and development, the illustration of the naw àmüz appears to be no accident. Rather, it directly informs us that the Miftăh was intended as a tool for teachers to lead and instruct students in a sultanate society.

\section{DIDACTIC IMAGES OF WONDERS AND CRAFTS}

Scattered clues allow us to speculate that Shadiyabadi and the makers of the Miftā $h$ had Islamicate cosmographies and wonder in mind when compiling this work. The clearest evidence for Shadiyabadi's interest in cosmography is his heavy reliance on the cosmographically ordered Farhang-i Qavvās. Moreover, the only other surviving manuscript linked with Shadiyabadi's authorship is the 'Ajā $i b$ al-Ṣana $\bar{\imath} \bar{\imath}$, a Persian adaptation of al-Jazari's twelfth-century book of wondrous automata. Shadiyabadi thus may have had a penchant for wonders-oriented literature. ${ }^{91}$ The layout and organization of the Miftāh's manuscript also show significant overlaps with the cosmographical genre writ large. Both genres, the cosmography and farhang, are catalogue-like books used for consultation. Like the Islamicate cosmography, the Miftăh appears to be concerned with widespread tropes about the universe rather than discursive science.

While we can never truly know the intentions of Shadiyabadi or the Miftăh's artists, it is generative to analyze the manuscript through the lens of cosmographies and wonder. Here, I argue that the Miftā h conveys the aesthetics of 'ajab. Instead of serving as a cosmography, it teaches its readers how to grapple with the unstable reality of wonder through the enjoyment of acquiring new knowledge. ${ }^{92}$ I pursue this analysis by focusing primarily on the Miftā $h$ 's illustrations of crafts. I also take into account the transcultural context of sultanate India in my interpretation of their 'ajab. Before moving on to crafts, however, a few words on the cosmography are in order. 


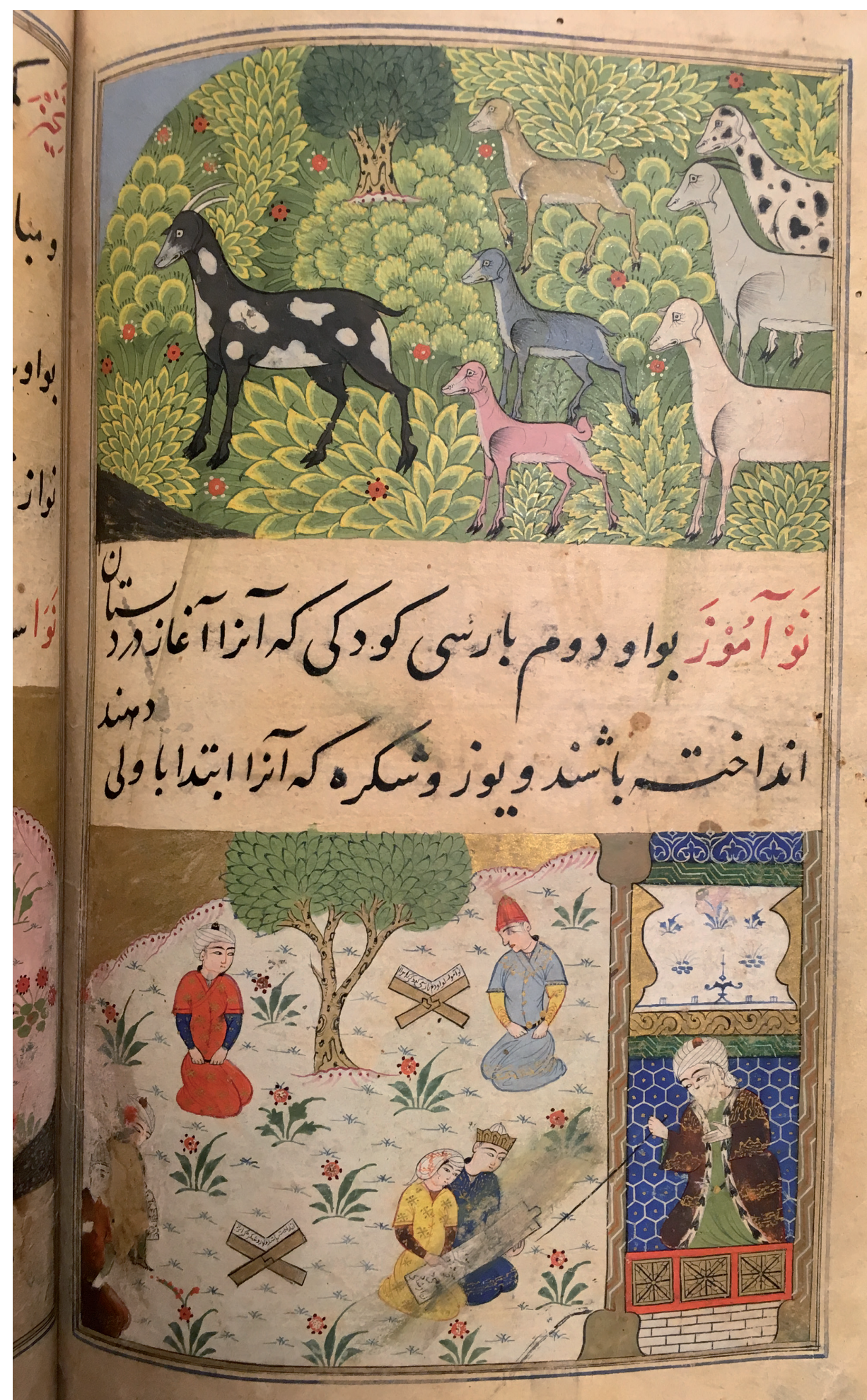

Fig. 21. New learner (naw āmūz). Miftāh al-Fużalā of Shadiyabadi, Mandu, ca. 149o. Above: $7.6 \times 12$; below: $8.2 \times 12 \mathrm{~cm}$, British Library Or 3299, f. 278b. (Photo: Courtesy of the British Library) 


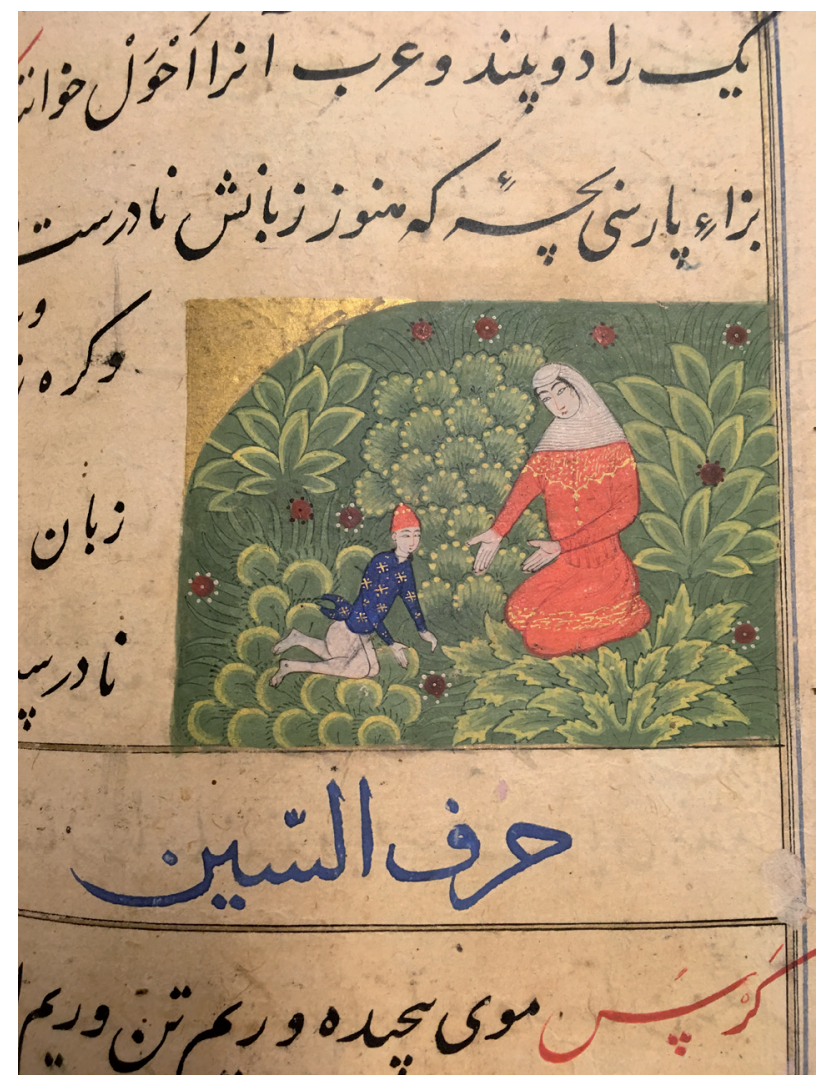

Fig. 22. Kazhmazh, Miftāḥ al-Fużalä’ of Shadiyabadi, Mandu, ca. 149o. Painted surface: $5.9 \times 7.9$ cm, BL Or 3299, f. 228 b. (Photo: Courtesy of the British Library)

Cosmographies, such as Ahmad-i Tusi's twelfth-century Persian text and Zakariyya' al-Qazwini's (d. 1283) thirteenth-century work, begin with sections on cosmic creations and end with worldly phenomena. ${ }^{93}$ The Miftăh does not follow a thematic order in this way, although it draws heavily on an earlier dictionary that does. In her study of medieval wonders-of-creation compendia, Persis Berlekamp has demonstrated how the images in these manuscripts codified tropes and fulfilled iconic, narrative, penumbral, and talismanic purposes. ${ }^{94}$ These categories are fairly self-evident. Iconic images call for the viewer's focused contemplation on wonders that may have been familiar tropes (figs. 2, 17). Narrative images tell stories (fig. 7). Penumbral visions refer to matters that cannot be fully envisioned or apprehended. Talismanic pictures are protective. The majority of the Miftāḥ's images are iconic or narrative. I have yet to dis- cover penumbral or talismanic images within the manuscript. Yet one feature that unifies all of these categories is their didacticism. The Miftăh's most Qazvini-esque images are of natural phenomena such as standalone animals and trees (figs. 2, 17). The manuscript, however, peculiarly elides images of the celestial cosmos. Instead, these wonders are relegated to textual definitions alone.

Some of the Miftāh's illustrations of crafts also demonstrate that wonder was central to its function. The illustrated definition of a vessel in the form an animal, the $t a k \bar{k} k$, is a primary example. ${ }^{95}$ Shadiyabadi defines takūk as "a vessel in the form of an animal" (șurāḥi bar șürat-i jānvar). ${ }^{96} \mathrm{~A}$ word with etymological roots in old Persian (Pahlavi), the takūk first appeared as an entry in a fourteenth-century Persian lexicon from India as well in as a few earlier dictionaries. ${ }^{97}$ It is useful to return to the first known Persian dictionary composed in India around 1300, the Farhang-i Qavvās, where one also finds the word takük in a section dedicated to pots, pans, and other vessels $(\bar{a} v a n d h \bar{a}) .{ }^{98}$ In fact, Shadiyabadi quotes his definition of takūkfrom the Farhang-i Qavvās verbatim. Unlike the Miftāh, the Farhang-i Qavvās cites a verse from the Persian poet Rudaki (d. 941) to illustrate the usage of the word takük. It reads, "the wine-drinker sips from the royal $t a k \bar{u} k$; drink happily in the new spring" (may kashān andar takūk-i shāhvār / khür bishādī rūzgār-i navbahār). Rudaki's verse implies the takūk's function as a drinking vessel. The later Tehran manuscript of the Miftăḥ clarifies: "A vessel of pottery or gold or an animal in porcelain, also made in the form of an ox or fish" (șurāhīi-yi sufātīn va yā zarrīn va yā bahìmin bar chīnī va bi-șürat-i gā v va māhī sāzand). ${ }^{99}$ Modern dictionaries also corroborate that the word takukk denotes zoomorphic vessel. ${ }^{100}$

The painting of the takūks in the Miftăh emphasizes that they are objects to behold and contemplate. It shows two goose-shaped objects seated in a green pasture (fig. 23). ${ }^{101}$ The geese are painted dark brown, but their stylized wings and beaks are gold. Although the swelling bellies imply their hollowness as vessels, the river in the bottom left corner of the painting conjures an outdoor rather than indoor setting. The taküks' feet, also gold, are not the typical webbed feet of geese, but rather form a cylindrical base, which are common supports for freestanding objects. ${ }^{102}$ Next to the two vessels 


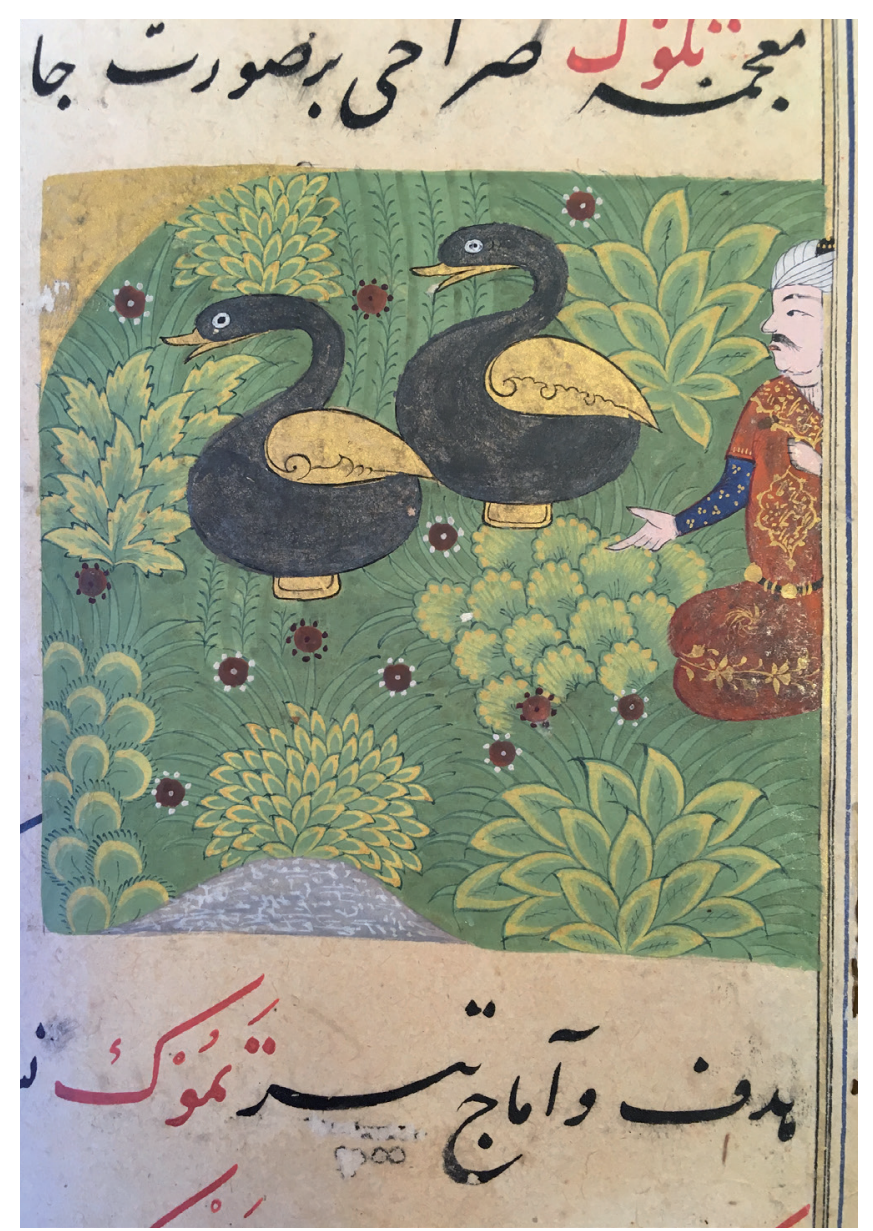

Fig. 23. Zoomorphic vessel (takūk). Miftāh al-Fużalä’ of Shadiyabadi, Mandu, ca. 149o. Painted surface: $7.8 \times 7.9 \mathrm{~cm}$, British Library Or 3299, f. 8ob. (Photo: Courtesy of the British Library)

is a human figure with one arm on his chest and the other hand pointing to the geese in a gesture that conveys engagement or fascination with the objects. Adjacent to takūk in the Miftāh are definitions of birds, although none of these textual entries matches the depiction of birds in the takūk painting. The adjacent birdrelated lemmas include the pheasant (turtak), wagtail (Pers. tarandak, Hind. mammolā), and baby pheasant (tūrang). ${ }^{103}$ Also unlike other, more realistic paintings of birds in the Miftāh (fig. 24), ${ }^{104}$ these illustrated geese command the gaze of a human who beholds the takūks' wonder.

The interpretation of these goose-shaped vessels as wondrous is the product of a transcultural materiality. On one hand, the work of A. S. Melikian-Chirvani and
Melanie Gibson has accounted for the survival of several Persian takūks. ${ }^{105}$ In fact, a blue and white glazed ceramic, bearing a possible attribution to Nishapur, is dated 897 (1491-92) (fig. 25). ${ }^{106}$ This date is within a decade of when the Miftāh was likely produced. Similar to the painting of taküks in the Miftăh, this object has a footed base and a stylized wing. On the other hand, in the context of Mandu, the Miftāh's painted takūk also evokes the hamsa (goose, gander), the Hindu lord Brahma's vehicle (vähana), which served as a common emblem for the Hoysala (1026-1343) and Vijayanagara empires (1343-1565) of the Deccan (fig. 26). ${ }^{107}$

Although countless examples survive in stone sculpture, the representation of the hamsa in metalwork from the Deccan sultanates establishes connections 


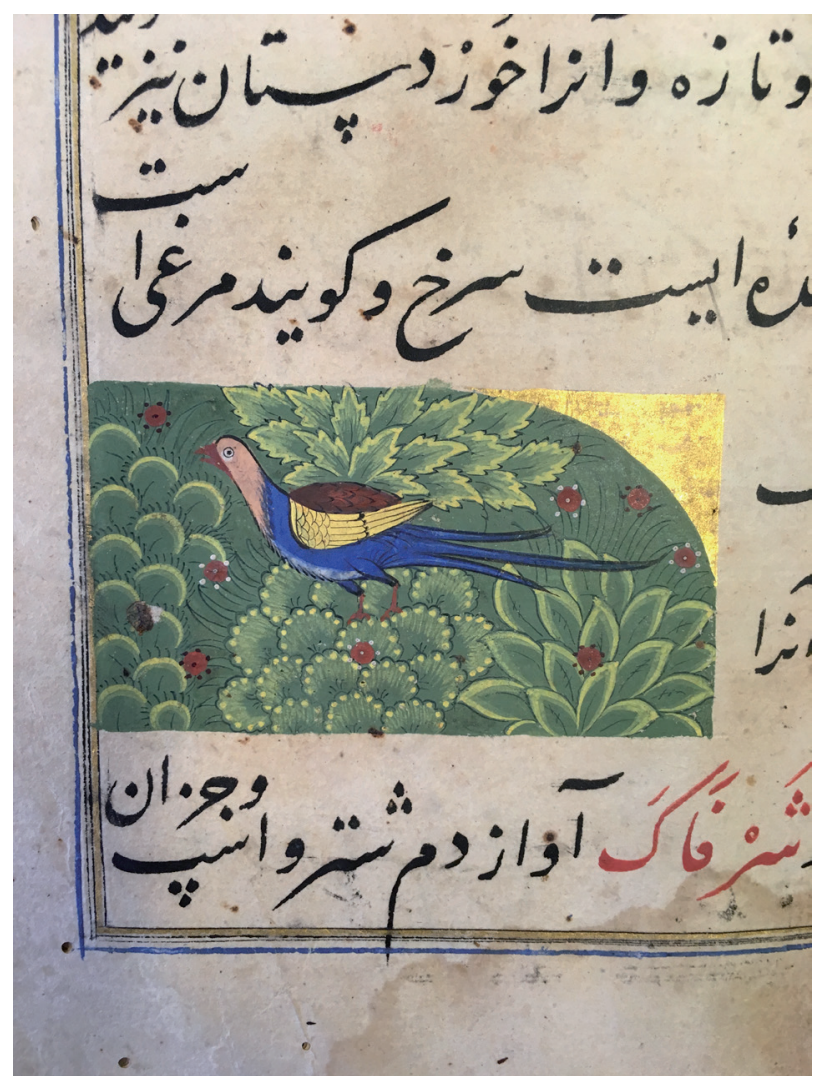

Fig. 24. Bustard, a bird that changes color (shavālak). Miftāh al-Fużalā of Shadiyabadi, Mandu, ca. 149o. Painted surface: $4.7 \times 6.8 \mathrm{~cm}$, British Library Or 3299, f. 189a. (Photo: Courtesy of the British Library)

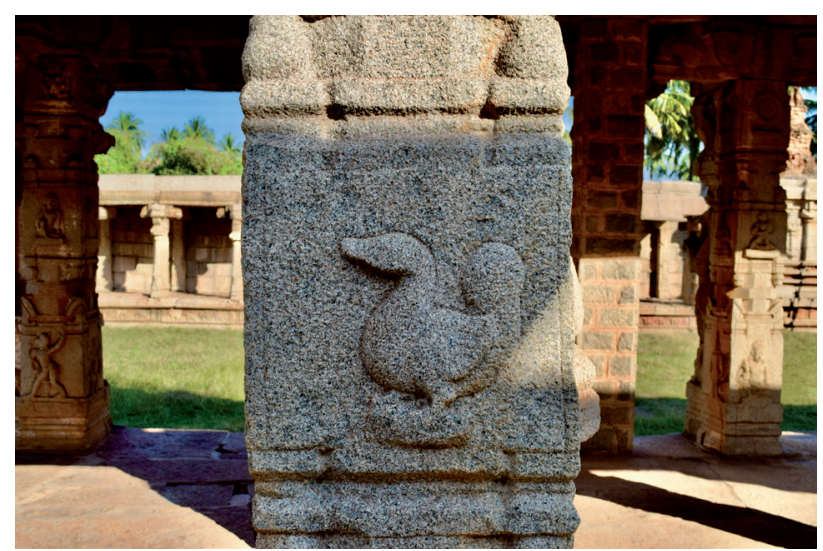

Fig. 26. Hamssa depicted on mandapa column, Acyuta Deva Raya Temple, Vijayanagara (ca. 1529-42), granite. (Photo: Vivek Gupta, January 2015)

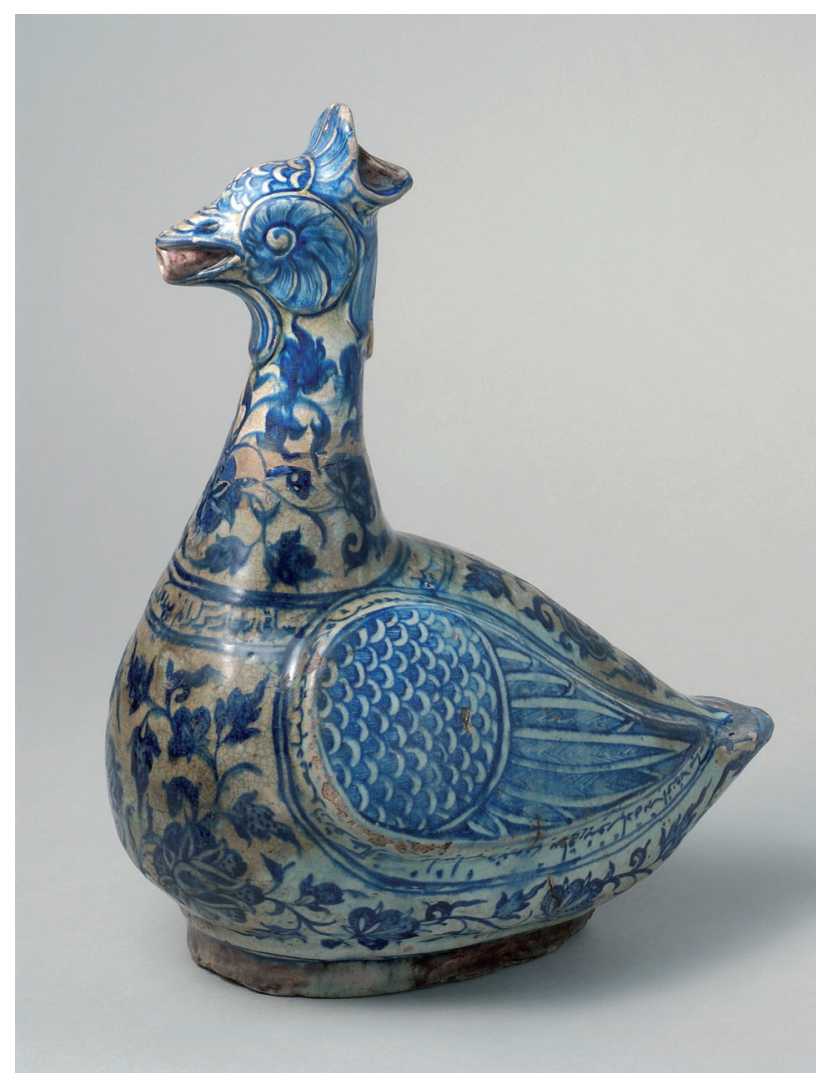

Fig. 25. Zoomorphic vessel (takūk), Nishapur?, dated 149192, glazed ceramic. Height: $33.6 \mathrm{~cm}$, Musée de Céramique, Sèvres, MNC 22687.

between the Miftāh 's painting and a concurrent material phenomenon (fig. 27). ${ }^{108}$ From monumental leogryphshaped cannons to small steel doorknockers, Deccan metal objects similar to this exemplary silvered-brass hamsa aquamanile (ca. fifteenth-sixteenth century) now in the collection of the Museum of Fine Arts, Boston, blend Indic and Islamicate forms in a distinctively Islamicate method of metalworking. ${ }^{109}$ Although Shadiyabadi's chosen word, takūk, stems from old Persian and lacks an Indic etymology, it is nevertheless possible that takūk forms adopted local animal typologies depending on context. Like the Miftăh's painting of takūk, the Boston ewer has an elongated neck with a stylized wing (fig. 27). The painting also appears to depict a metal object, like the Boston ewer and quite unlike the Nishapur 


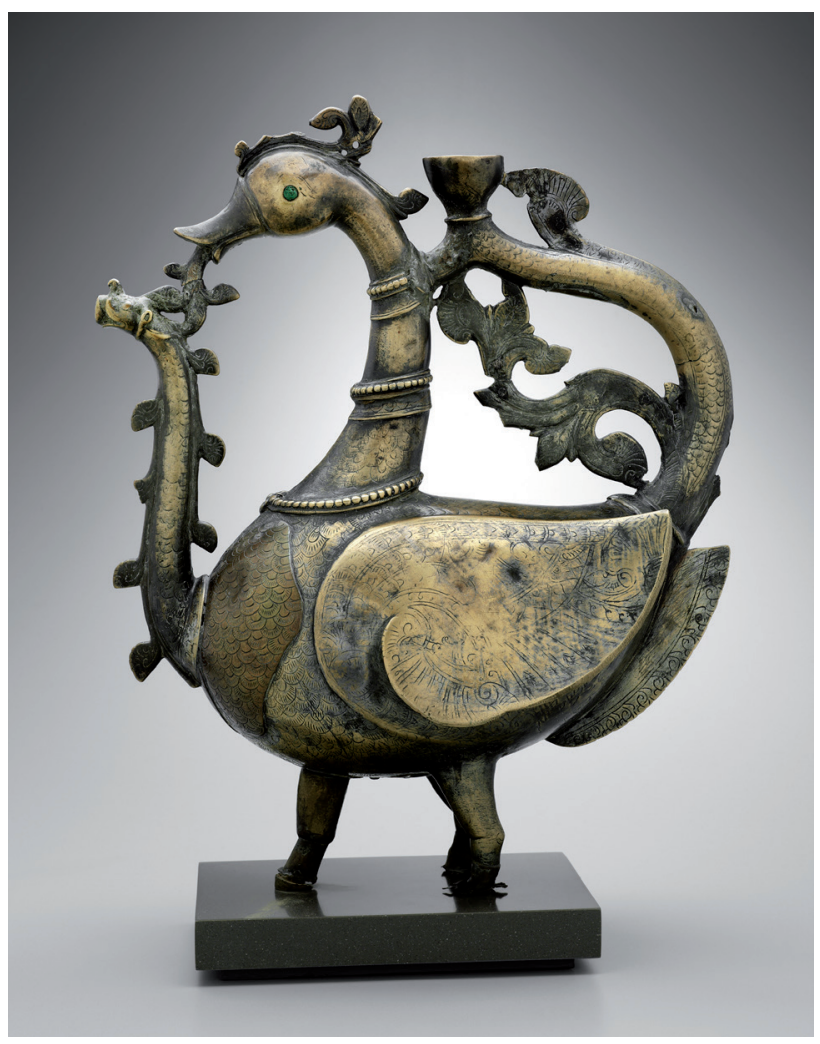

Fig. 27. Ewer in the form of a hamsa, Deccan, sixteenth century, bronze with layer brass repairs, copper arsenic paste. Inscribed: "Sulțān Bakcham(?) Salmān, glorious in his splendor." Height: 38.5 cm, Museum of Fine Arts, Boston, 37.470.

vessel. However, the Boston ewer features additional details: a crocodile-headed spout at the front and a flared handle. Three bands divide the ewer's neck, accentuating its length. These decorative features may have been added at a later point, given that there are layers of brass repairs on the object. Its two separate holes, one for pouring in, and the other for decanting water, show that it was meant to hold liquid. ${ }^{110}$

In spite of their visual differences from the illustrated takūk, the existence of objects such as the Nishapur and Boston ewers supports the idea that the Miftāh and the earlier Farhang-i Qavvās were depicting a real, observed world, and not one that was purely fictional. The illustrated definition of the takūk merges the animal qualities of a manmade craft with its status as a marvelous object. The existence of both the Nishapuri and Boston

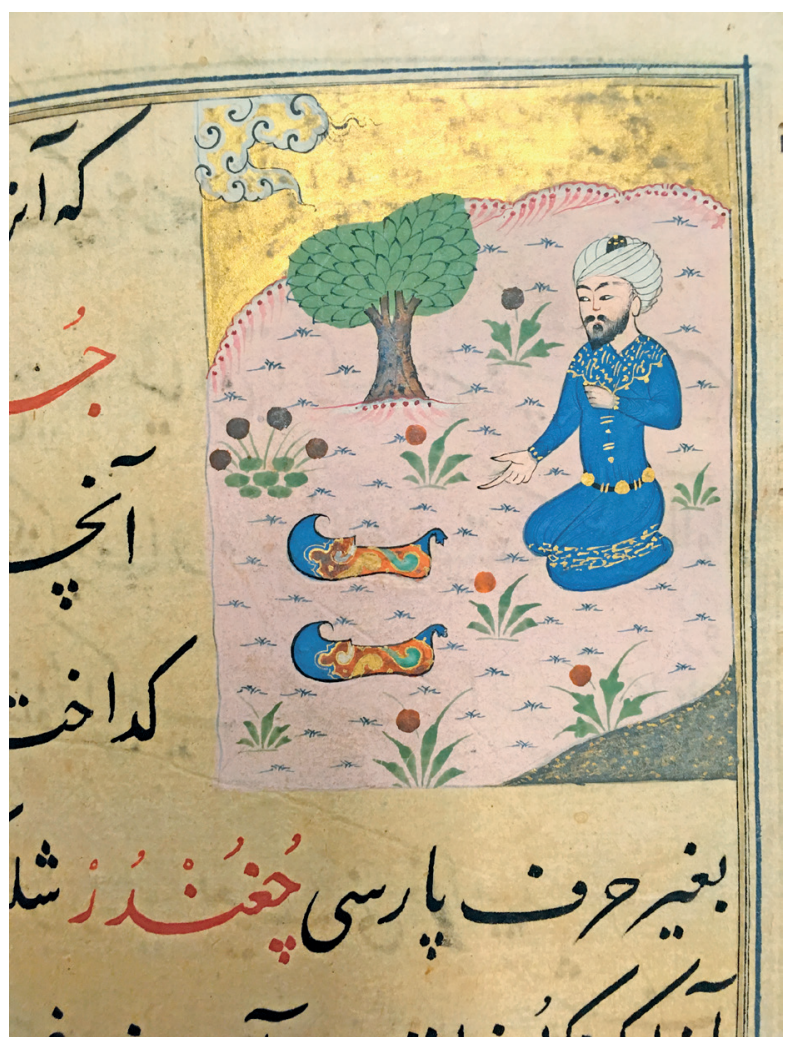

Fig. 28. Boot-stocking (chapdār). Miftāh al-Fużalā of Shadiyabadi, Mandu, ca. 149 o. Painted surface: $8.2 \times 6.1 \mathrm{~cm}$, British Library Or 3299, f. 95b. (Photo: Courtesy of the British Library)

takūks suggests that this illustrated definition may have addressed audiences from multiple cultural orientations. The reader of the Miftāh beholds the takūks' wonder just as the figure in the illustration does (fig. 23). In this illustration, the takūks are liminal objects. Although they are set within a natural environment, they have one clear trait, their cylindrical base, that uncovers their status as a manmade craft. The liminality of the takük-its ability to evoke the natural and be manmade-would have added to its wonder. ${ }^{111}$ Whether channeling water as an ewer, exhaling smoke as an incense burner, or firing a cannon ball as artillery, animal vessels like the takūk could come to life, purify water, and ward off evil.

A web of interrelated texts, images, and definitions within the Miftāh also led readers to comprehend 
particular qualities of crafts as wondrous. Let us begin with the main illustrated definition in question, the boot stocking or chapdār (fig. 28). ${ }^{112}$ This is one example of an illustration that is illuminated by other images in the Miftāh. For the chapdār Shadiyabadi provides a rather terse definition: "feet-coverings that are also called jurmūq." 113 Both chapdār and jurmūq are absent from the Farhang-i Qavvās, despite the fact that they would have naturally fit the sub-chapter on clothing. ${ }^{114}$ The illustration shows a bearded male in a luxurious blue robe with gold-thread embroidery whose his right hand is pointing directly at the stockings. Under a golden sky, he sits on the ground between a tree and a river as if encountering the stockings in a natural environment. This depiction of encountering a craft in nature aligns with the illustration of the takük. The two stockings that illustrate chapdār are exquisite. With a point at their tip and a tooth at their rear, the curved outlines of these shoes are calligraphic. Within the stocking, there are swirls of gold illumination with highlights of green, yellow, and dark pink, recalling bookbinding decorations. None of the fanciness of these chapdār is specified in the definition. Here, the artist took the liberty of depicting the fabulously designed surface of clothing that inspires wonder. The way in which the Miftäh defines other kinds of shoes informs our understanding of the chapdār as well (fig. 29). The golden shoes, or zarinah kafsh, are defined as a kind of royal shoe made of gold and brocade, and with the exception of the pādshāh (king), no one else wears them. ${ }^{115}$ The painting illustrates a ruler seated on a golden throne extending his foot as a servant hands him a pair of pointed golden shoes. The dense gold of the ruler's throne lends the whole scene a sumptuous tone. Unlike the chapdār, these foot-coverings are simply rendered in gold with darkened points. ${ }^{116}$ In contrast to the chapdār, which are observed within nature, the golden shoes are featured within the pageantry of a court. Other shoe-related words are not depicted in the Miftāh at all. The khärkafsh, or boot covering, is defined as "a foot-covering that the Arabs call a jurmūq."117 The lack of illustration for this word may in turn highlight the outstanding visual qualities of the chapdār.

The path to interpreting these stockings as wonderinducing is not straightforward. It is not merely one, but several other images in the Miftā $h$ that guide the reader towards construing the illustrated chapdār as represent-

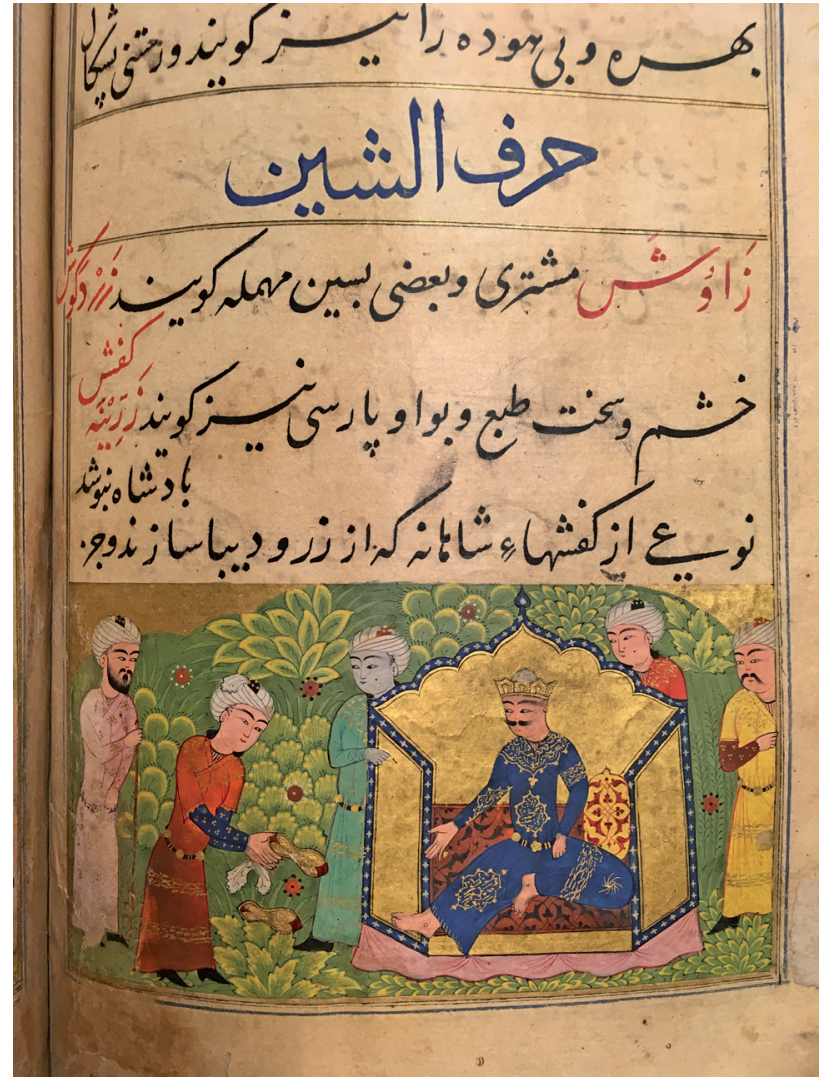

Fig. 29. Golden shoes (zarinah kafsh). Miftāḥ al-Fużalā of Shadiyabadi, Mandu, ca. 149o. Painted surface: $6.2 \times 12 \mathrm{~cm}$, British Library Or 3299, f. 146b. (Photo: Courtesy of the British Library)

ing more than high-quality design. A close reading of these other definitions gives us greater insight into this single entry. In what follows, I propose that one way of interpreting the chapdār is through their Abū qalamūn quality - that is, their multicolor, unstable surface and ability to change color. By reading several medieval sources, including Nasir-i Khusraw's eleventh-century Safarnāmah (Book of Travels) and Ibn Manzur's thirteenth-century Lisān al-'Arab (The Tongue of Arabs), Matthew Saba arrives at a definition of būqalamūn or Abū qalamūn that encompasses two distinct meanings. The first is that of a multi-colored textile or silk cloth, the colors of which transform as they move; and the second is a bird that can change color. ${ }^{118} \mathrm{He}$ also demonstrates the importance of Nasir-i Khusraw's definition of būqalamūn as a type of pottery with an iridescent 
sheen. ${ }^{119}$ This wonder-inducing quality of visual instability is perceivable in the illustration of chapdār.

The readers of the Miftăh likely had knowledge of the two meanings of Abü qalamūn. For instance, the Persian poet Sacdi (d. 1291), whose works were widely read in India, used būqalamūn to mean iridescent. ${ }^{120}$ Qavvas includes this word his dictionary and states that "it is a Rumi (Anatolian) cloak of [seven] colors" (jämah ist rümí, [haft] rang). ${ }^{121}$ The first Mughal Emperor Babur (r. 1526-30) describes his encounter with a colorful bird known as būqalamūn. ${ }^{122}$ Muhammad al-Mufti alBalkhi's Majma' al-gharā'ib (Collection of Oddities), commissioned in 1555 and presented to Pir Muhammad Khan of Balkh, which was copied and illustrated multiple times in seventeenth-century India, opens with a quatrain that describes the world as büqalamūn, or everchanging. ${ }^{123}$ By the eighteenth century, the South Asian philologist Azad Bilgrami even innovated a poetic device that he classified as Abu qa lamūn. Writing in Arabic, he defines this device as follows, "It is language that is like a woolen cloak saturated with colors. Such vibrancy is called 'Abu qualamūn' and it is marked by a shared word between two or more languages." ${ }^{\prime 24}$ Azad indicates that Amir Khusraw (d.1325) specialized in a version of $A b \bar{u}$ qalamün in which "the speaker uses Arabic, but the essence (qalb) of his speech is Persian, or the speaker uses Persian, but the essence of his speech is Arabic."125 The fact that Abū qalamūn was utilized to denote a shapeshifting multilingual punning device indicates a strong association between būqalamūn and the qualities of polyvalence and instability.

With regard to the ornithological meaning of büqalamūn, the dictionary illustrates the shavālak, or bustard, as a multicolored bird (fig. 24). ${ }^{126}$ Shadiyabadi defines the shavālak as "a bird, that is red, and it is said that it is a bird that always changes color. The Arabs call it būburāqsh" (parandah ìst, surkh, va gūyand murghīast kih har zamān rang bigardānad va 'arab ānrā büburāqsh güyand) ${ }^{127}$ Modern dictionaries state that büburāqsh is synonymous with büqalamūn. ${ }^{128}$ The illustration shows the multicolored bird alone in a thicket; its wings are red and gold, its long plume is blue, and its head is pink. Shadiyabadi's definition of shavālak thus would make the reader aware of this bird's fabulous qualities. ${ }^{129}$

With regard to the textile-related definition of būqalamūn, a number of illustrations in the Miftāh pre- pare a student to be enchanted by the surface of the chapdār. The Miftāh features at least seven illustrations related to the process of producing cotton and silk textiles. These include the wooden instrument used for separating cotton from its pod, the bow used by a cotton dresser, a cage spool, the reed used by weavers (syphon), the foot treadle (fig. 11), and the dyer. ${ }^{130}$ Specific plants used for textiles are illustrated as well. ${ }^{131}$ The audience of the Miftāh would thus be equipped with the tools needed to fathom the distinct stages of textile production, and to appreciate when textiles were made as būqalamūn. It is also worth bearing in mind that fifteenth-century Malwa was the site of much cotton harvesting and weaving, which suggests a practical application for such knowledge. ${ }^{132}$

The world of fifteenth- and sixteenth-century Indian textiles was a markedly transcultural one, and none of the cotton farmers and weavers were high-class Muslims. The Miftāh nevertheless depicts articles of clothing commonly worn by figures beyond the court. For example, Shadiyabadi defines the Turkic word $c h \bar{u} k h \bar{a}$ as a robe worn by yogis (fig. 30). ${ }^{133}$ The illustration shows a stumpy barefooted figure whose face and headgear have been smudged. The yogi wears a long pale blue robe with a red collar. His right sleeve is lengthened, a common sartorial signifier of a Suf. Thus, the reader becomes aware of the valences of Indo-Islamicate cultures of dress. While obtaining expertise in textiles and dress, the reader would also become immersed in their transculturation. One can imagine that the readers of the Miftăh may have needed such language to communicate their sartorial needs or desires to artisans, or to incorporate these experiences into their poetry.

The visual knowledge of these ornithological and textile definitions read in tandem with the circulating literary allusions to büqalamūn would have facilitated a sophisticated and informed interpretation of the illustrated definition of chapdār. With all of these associations, a well-taught student would be more sensitive to the wonderfully designed surface of this apparel.

The illustrations of the takūk and chapdār as crafts set in a natural landscape beheld by a viewer emphasizes wonder as a key theme within the Miftăh's illustrations. One function of the Miftăh was clearly to inspire a state of wonder $(t a j j u b)$ and contemplation of new words. These illustrations of crafts, in addition to the more 


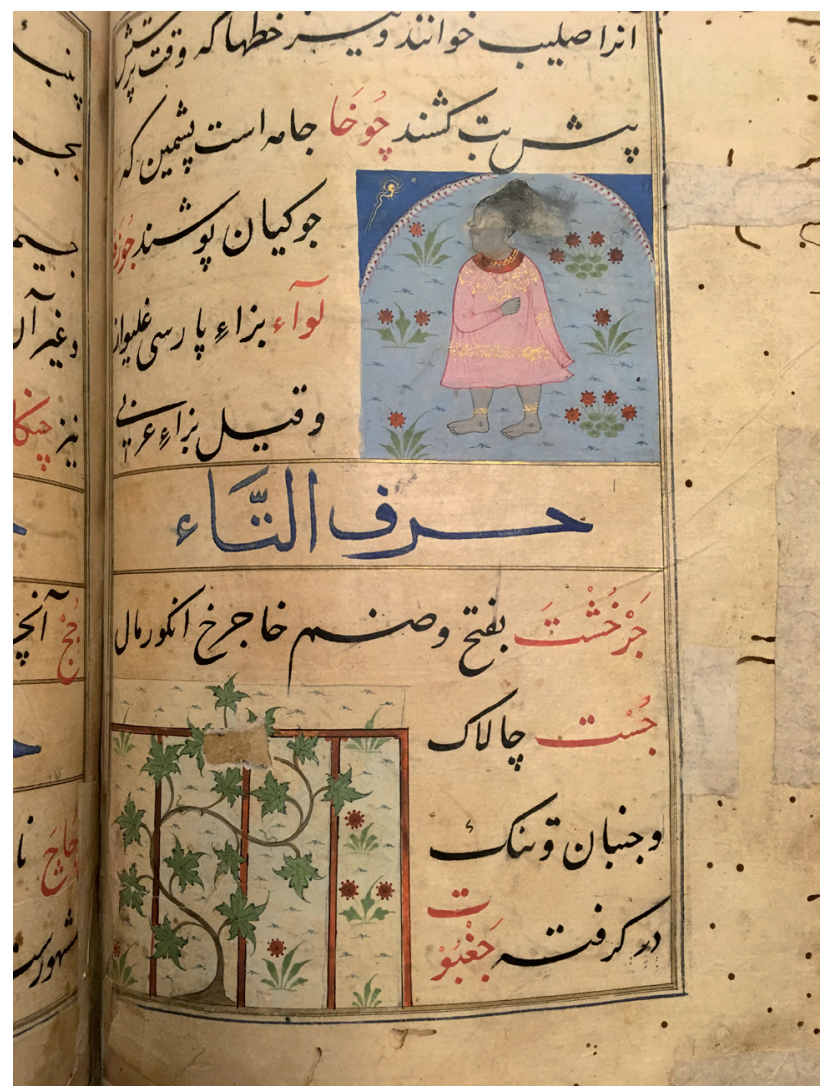

Fig. 3o. Robe worn by yogis $(c h \bar{u} k h \bar{a})$. Miftāh al-Fu̇̇alā of Shadiyabadi, Mandu, ca. 149o. Painted surface: $6.1 \times 6.1 \mathrm{~cm}$, British Library Or 3299, f. 93b. (Photo: Courtesy of the British Library)

obvious wonders-of-creation illustrations and the other evidence outlined above, suggest that Shadiyabadi and the makers of the Miftā $h$ had cosmographies and wonder in mind when conceiving the Miftăh.

\section{A FINAL EXAMPLE: WONDER FOR A YOUTH}

I close this article with one final illustrated definition that conflates a youth (bachah, küdak) and wonder. Shadiyabadi defines the dìv-kulüch as "a human child who is changed (possessed) by the demon" (bachah-i mardum kih dīv badal kardah bāshad). ${ }^{134}$ Steingass defines $d \bar{\imath}$-kulūch as "an epileptic boy." 135 In the Miftāḥ's illustration, a young boy extends his hand as if speaking and sits across a river from a larger figure, a bare-chested and horned demon. The painting occupies the entire

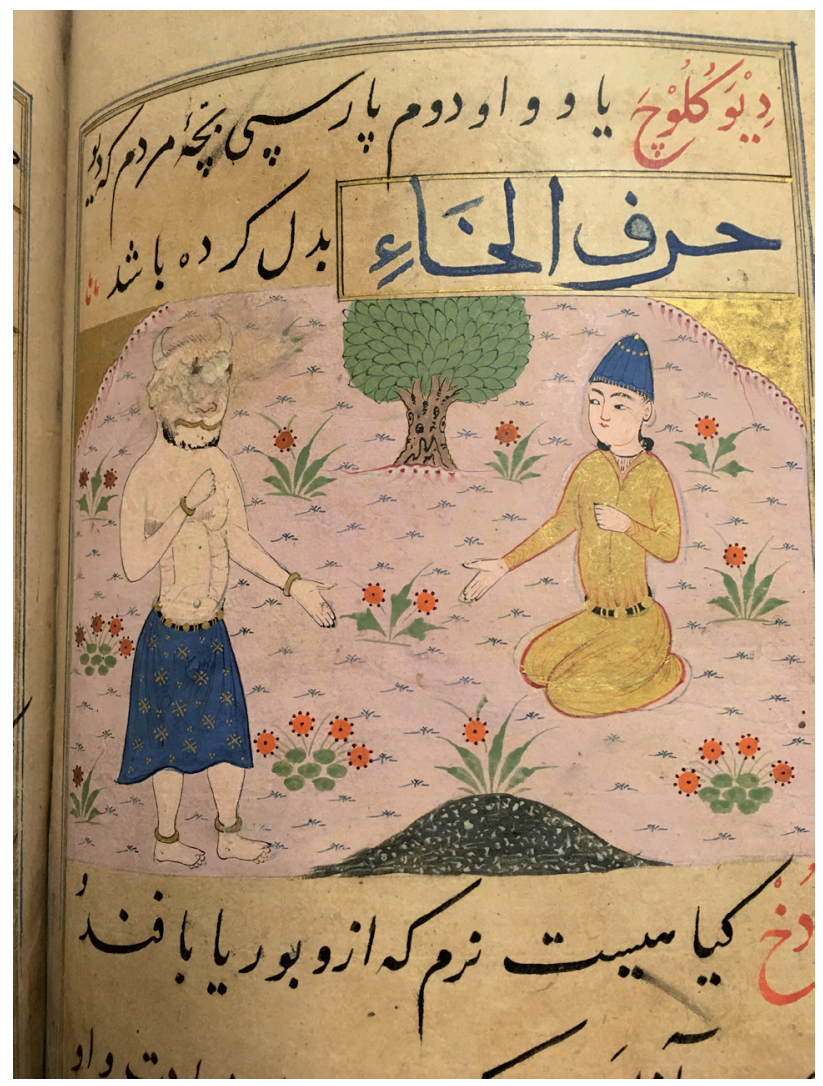

Fig. 31. Child possessed by a demon (dīv-kulūch). Miftāḥ alFużalā of Shadiyabadi, Mandu, ca. 149o. Painted surface: $8.2 \times 12 \mathrm{~cm}$, British Library Or 3299, f. 116b. (Photo: Courtesy of the British Library)

width of the page, indicating that the calligrapher or painter regarded the image as significant enough to be allocated this amount of space (fig. 31). A similar scene occurs in the definition for kakh-jhandah (fig. 32), a synonym of $d \bar{v} v .{ }^{136}$ Here, the young boy's hand points away from the other figure - a large, dark, horned demon who appears to be speaking. Again, the painting fills the entire width of the page, and the meta-didactic image of the bookstand (kirakh) appears in the illustration below. Here, the dark divv extends his left arm as if teaching: the student receives knowledge from this otherworldly creature.

These two illustrations suggest that $d \bar{v} v \mathrm{~s}$, in spite of their supposed fearfulness, may have served as companions for children. The similarity of the boy's clothing in both illustrations - a mustard-colored robe and blue hat - may indicate that he is a stock figure of a student. 


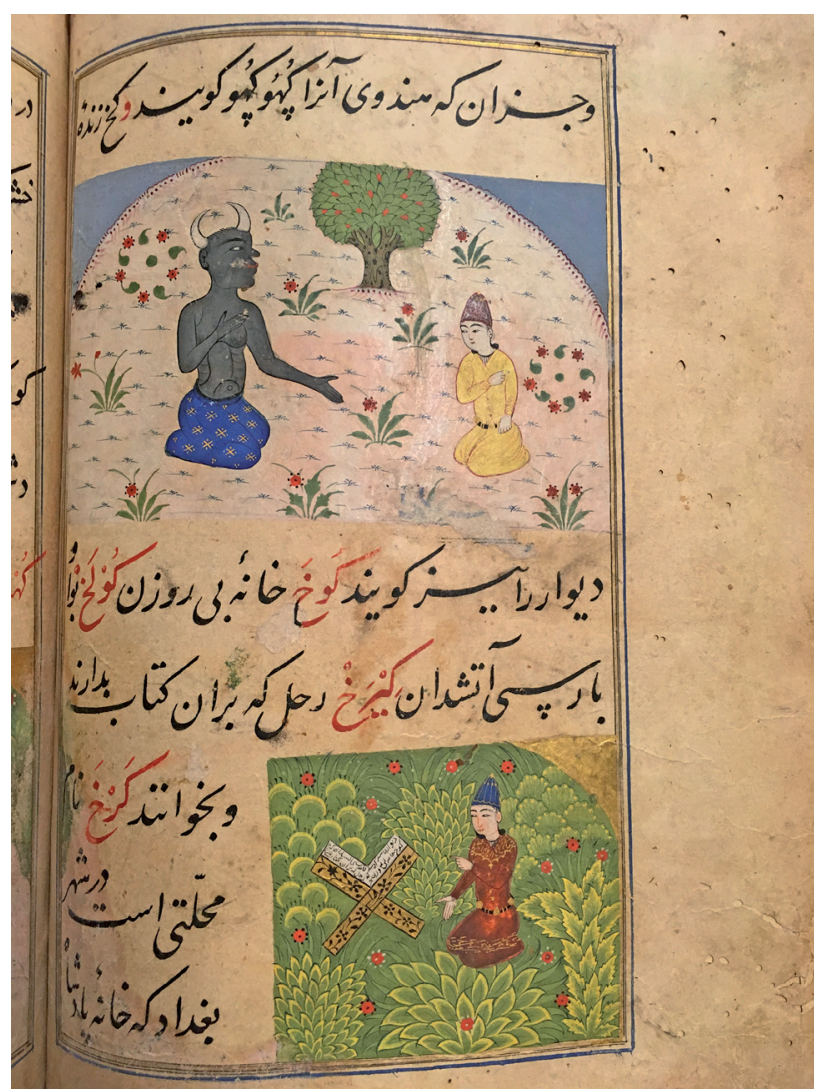

Fig. 32. Top: demon (kakh-jhandah); bottom: bookstand (kïrakh). Miftāh al-Fużalā of Shadiyabadi, Mandu, ca. 1490. Top: $7.3 \times 12$; bottom: $6.1 \times 7 \mathrm{~cm}$, British Library Or 3299 , f. 223b. (Photo: Courtesy of the British Library)

Whereas the definition of $d \bar{\imath}$ - $k$ kulüch concerns children specifically and thus a child is naturally expected to appear in the illustration, in the case of kakh-jhandah the textual definition does not require the depiction of the child. ${ }^{137}$ Since monsters such as dìvs were stock characters in Firdawsi's Shāhnāmah, their inclusion here was likely intended to aid a new student's reading of this text. To my knowledge, however, the dìv-kulüch and the $k a k h$-jhandah are not figures that appear in the Shāhnāmah. As an otherworldly beast, the dīv-kulūch would most likely strike fear into the heart of a child. In fact, the div-kulüch's text suggests that the youth is crazed, wonderstruck, and perhaps even driven into an epileptic seizure by the $d \bar{\imath} v$. However, the illustration does not depict this. It shows a seemingly friendly interaction between the div and boy. The div in this case may even serve as a companion for the youth. These two nearly identical images of $d \bar{\imath} v$ s and children would thus be points of entry for the viewer, perhaps a youth, or someone reading to a child, into the world of wonder.

\section{CONCLUSION}

Through a study of British Library Or 3299, we have seen that the Miftăh employs wonder to educate new students. Images, and not only texts, transmitted knowledge. The form and function of the Miftăh also lead us to reflect on what it meant to shape this entirely new genre of manuscript in sultanate India. We may describe a number of books as a vade mecum (Latin: "go with me"), but they adhere to the category of handbook or manual in different ways. Cosmographies can capture a tropology for a given book culture, not necessarily in terms of text, but frequently in painting. Albums (muraqqa s) - collections of various paintings, calligraphies, etc. that became popular in the fifteenth century-may represent a particular artistic worldview and can be taken as a guide to comprehending the concerns of a cultural habitus. ${ }^{138}$ Anthologies, by their nature, also aggregate and canonize materials for a given milieu. They can thus be taken as a guide to gaining a clearer understanding of the main concerns of an artistic or intellectual context. It is for this reason that David Roxburgh once called the anthologies of Iskandar Sultan (d. 1415) prime examples of the vade mecum. ${ }^{139}$

As its title suggests, the Miftā $h$ is indeed a key for the learned. In terms of styles and provenance of its contents, it does not contain the same diversity as albums or anthologies, which can provide a clearer view of how distinct artistic practices may have been valued at a particular historical moment. But this article demonstrates how the Miftăh guides us through the little-understood dynamism of the sultanate visual world. Like the cosmography, the Miftāh codifies tropes. Like the album or anthology, there appears to have been a considerable amount of collecting and curating agency involved in the creation of the Miftah $h$. Whereas in the album this agency belonged to a book artisan selecting various paintings or calligraphies, or to an intellectual choosing verses from both the past and present to anthologize, in the Miftă $h$ the agency may be assigned to the artists or intellectuals at the moment of conception and making. 
This individual had to choose which entries required paintings and which did not, and how the idea of a particular word could best be captured and codified in a single image as a trope.

In light of its implications for medieval and early modern material culture, the Miftāh must now join the shelves of other select texts that historians of Islamic and South Asian art keep within close reach. The manuscript's illustrated and non-illustrated definitions shed light on dozens of material artifacts, particularly from the sixteenth-century Deccan sultanates. I believe that this is no accident. Because of its central location, Mandu's material culture was a fulcrum for other contemporary and later courts. While it may have only flourished for roughly a century, it likely established certain models of material culture that crystallized later.

In the final analysis, this article calls attention to the significance of combining art historical with philological study in establishing word-image relationships and assigning names and meanings to premodern images and objects. The illustrated definitions must be understood as a close synthesis of text and image: one did not follow from the other. Images are recognizable as definitions that fulfill a clear didactic purpose. The artists of this manuscript were likely rather sophisticated or had an intellectual guide to help them plan the illustrations. Shadiyabadi might have even supervised the making of the manuscript. Shadiyabadi and the artists of the Miftāh innovated a manual for their times. As Skelton reminded me, the Miftăh contains traces of the many more now-lost sultanate manuscripts. Although fifteenthcentury Mandu may seem to be a faraway imagined place, reactivating the Miftāh affords us the immediate pleasure of becoming new students ourselves.

\section{University of Cambridge,}

Cambridge, $U K$

\section{NOTES}

Author's note: The author acknowledges Scott Redford, Barbara Brend, Charles Melville, Ursula Sims-Williams, and Daina Buseckaite for their support. He is grateful to Gülru Necipoğlu, Maria Metzler, and the reviewers for their forbearance. He also thanks Rajeev Kinra for his conversation about the Miftäh after a chance encounter at the British Library. Parts of this study were presented at Jawharlal Nehru University, the University of Edinburgh, and the University of Cambridge. This article grows out of the author's PhD thesis, "Wonder Reoriented: Manuscripts and Experience in Islamicate Societies of South Asia, ca. 1450-16oo" (SOAS, University of London, 2020). I dedicate this article to Professor Alka Patel and all Indo-Islamicists who have followed in her impossible path.

1. Aditya Behl, Love's Subtle Magic: An Indian Islamic Literary Tradition, 1379-1545, ed. Wendy Doniger (New York: Oxford University Press, 2012), 6o-108; Qamar Adamjee, "Strategies for Visual Narration in the Illustrated Chandayan Manuscripts" (PhD diss., Institute of Fine Arts, New York University, 2011).

2. Dilorom Karomat, "Turki and Hindavi in the World of Persian," in After Timur Left: Culture and Circulation in Fifteenth-Century North India, ed. Francesca Orsini and Samira Sheikh (Delhi: Oxford University Press, 2014), 143, 164.

3. Maria Eva Subtelny, "Alī Shīr Navā'̄î," EI3. Consulted online March 18, 2021: <http://dx.doi.org/10.1163/1573-3912_ei3_ COM_23837>

4. See the illustration of the $y \bar{u} z$, which means "to search," or can refer to a small dog or leopard. The illustration shows both animals, with the dog following the leopard. BL Or 3299, f. 3o2b.

5. See, e.g., the illustration of the kallah, "pleasure place," with a kalbah, "canopy," shown above the painting. BL Or 3299, ff. 241b-242a.

6. BL Or 3299, turtles: ff. 56b, $156 \mathrm{a}$; porcupines: ff. $86 \mathrm{a}, 16 \mathrm{ob}$; monkeys: ff. 73a, 245b; animal dens: ff. 198b, 235b; and yawns: ff. $65 \mathrm{a}, 268 \mathrm{~b}$.

7. Karomat, "Turki and Hindavi," 132, following Baevskiǔ, Early Persian Lexicography; Rajeev Kinra makes this point about the Farhang-i Qavvās (around 1300) because its author claims as a motive the desire to aid in comprehending "the poetry of past masters, especially the Shāhnäma." See Kinra, "This Noble Science," 364, and Stefano Pellò, "Local Lexis? Provincializing Persian in Fifteenth-Century North India," in Orsini and Sheikh, After Timur Left, 175.

8. A. T. Adamova and Manijeh Bayani, Persian Painting: The Arts of the Book and Portraiture (London: Thames \& Hudson, 2015), 175-77.

9. BL Or 3299 , ff. 104b, 242a. Compare the depiction of an atrium on f. 242a to Bodleian Elliot 325, f. 124b.

10. Norah Titley, Persian Miniature Painting and Its Influence on the Art of Turkey and India (London: British Library, 1983), 171-72; J. P. Losty, The Art of the Book in India (London: The British Library, 1982), 66-67; Barbara Brend, Perspectives on Persian Painting: Illustrations to Amìr Khusrau's Khamsah (London: RoutledgeCurzon, 2003), 86-87; and Élö̈se Brac de la Perrière, L'art du livre dans l'Inde des sultanats (Paris: PUPS, 2008), 281. It is also catalogued in Charles Rieu, Supplement to the Catalogue of the Arabic Manuscripts in the British Museum (London: Trustees of the British Museum, 1894), 116; Charles Ambrose Storey, Persian Literature: A Bio-bibliographical Survey (London: Royal Asiatic Society, 1927), 13; and Muhammad Dabir Siyaqi, Farhanghā-yi Fārsī va Farhang-günah-hā (Tehran: Isparak, 1989), 66.

11. Norah Titley, "An Illustrated Persian Glossary of the Sixteenth Century," The British Museum Quarterly 29, no. 1/2 
(Winter 1964-65): 15-19. A. Jan Qaisar and Som Prakash Verma, "The Miftah-ul Fuzala': A Study of an Illustrated Persian Lexicon," in Art and Culture Painting and Perspective, vol. 2, ed. Ahsan Jan Qaisar and Som Prakash Verma (Abhinav Publications: New Delhi, 2002), 17-32. Earlier notices of the book include Sidney Churchill, "A Modern Contributor to Persian Literature: Rizá Kulí Khán and His Works," The Journal of the Royal Asiatic Society of Great Britain and Ireland 18, no. 2 (1886): 196-206, and Carl Salemann, "Beilage V. Chronologisches verzeichnis der Farhange," Mélanges Asiatiques 9 (1883): 517 .

12. Barbara Brend, discussion with author, November 2017.

13. Karomat, "Turki and Hindavi in the World of Persian." Solomon I. Baevskil̆, Early Persian Lexicography, trans. N. Killian (Global Oriental: Kent, 2007) includes a short entry on the Miftāh, 109-10.

14. BL Or 3299, f. 4 b.

15. Titley, Persian Miniature Painting, 171-72; and Losty, Art of the Book in India, 66-67.

16. Moya Carey, Persian Art: Collecting the Arts of Iran in the $19^{\text {th }}$ Century (London: V\&A, 2018), v-vi. The Miftāh also features in a footnote of Churchill's 1886 article on the contents of Riza Quli Khan's library, which is the first mention of the work in an English publication and demonstrates that Churchill himself examined the manuscript. Or 3299 must have thus entered the museum before Churchill was formally stationed in Iran, but this does not mean the manuscript was not purchased in Iran. A mostly illegible note on the manuscript's final folio (306b) in Persian with the date $1269\left(185^{2-53}\right)$ scribbled five times may have been added during a significant moment in the manuscript's itinerary, such as when it left India.

17. Vivek Gupta, "Wonder Reoriented: Manuscripts and Experience in Islamicate Societies of South Asia (ca. 1450-16oo)" ( $\mathrm{PhD}$ thesis, SOAS University of London, 2020), offers a full study of this manuscript.

18. Phillip Wagoner and John Henry Rice, "From Delhi to the Deccan: Newly Discovered Tughluq Monuments at Warangal-Sultānpūr and the Beginnings of Indo-Islamic Architecture in Southern India," Artibus Asiae 31 (2001): 83. The Hindolā Mahal also caught the attention of K.A.C. Creswell; see "The Vaulting System of the Hindola System at Mandū," Journal of the Royal Institute of British Architects 25, no. 11 (1918): 237-45.

19. Gülru Necipoğlu, "From International Timurid to Ottoman: A Change of Taste in Sixteenth-Century Ceramic Tiles," Muqarnas 7 (1990): 136-70; Yves Porter, "Décors émaillés dans l'architecture de pierre de l'Inde centrale: les monuments islamiques de Mandu (15e-16e siècles)," Archéologie islamique 7 (1997): 125; and Vivek Gupta, "Interpreting the Eye ('ain): Poetry and Painting in the Shrine of Ahmad Shāh al-Walī al-Bahmanī (r. 1422-1436)," Archives of Asian Art 67, no. 2 (2017): 189-208.

20. This is exemplified in the cosmography of Ahmmad-i Ṭūsī (BL Or 14949), made in early sixteenth-century India. See Gupta, "Wonder Reoriented," for a full discussion of this manuscript.
21. Kalpasūtra, 1439, Mandapadurga (National Museum of Delhi, MS 49.175); and Kalpasūtra, ca. 1470, Mandu (location unknown).

22. Būstān, National Museum, New Delhi, MS 58.28-14. Comparing this manuscript to Fitzwilliam MS 261 might be a productive avenue forward. The Fitzwilliam manuscript is dated December 7, 1505, by its colophon, and ascribed to Kashmir. This date is only a few years after Mandu's Būstān $(1502-3)$. However, during the past several years Mandu's Büstān has been inaccessible to scholars, as the National Museum has been unable to locate it. See Emma Flatt, The Courts of the Deccan Sultanates: Living Well in the Persian Cosmopolis (Cambridge: Cambridge University Press, 2019), 17-24, for an explanation of the term "Persian cosmopolis" in line with how I use it here.

23. Bodleian MS Elliot 237, f. 1oga; Michael Brand, "The Khalji Complex in Shadiabad Mandu (India)" (PhD diss., Harvard University, 1987), 255.

24. Bodleian MS Elliot 237, f. 108b; Brand, "Khalji Complex," 253 .

25. In consultation with the Persian manuscript, I quote an edited translation from Brand, "Khalji Complex," 255.

26. Yves Porter identifies similar kinds of decoration from late fifteenth-century Malwa, particularly on the Jahāz Mahal and Chishtī Khān kī Mahal in Mandu, and the Malkūm Khān kī koțhī in Nālcha. See Porter, "Décors émaillés dans l'architecture de pierre de l'Inde central."

27. Brand, "Khalji Complex"; Yves Porter, "Khalji architecture of Mâlwa in Light of the Ma'âser-e Mahmudshâhi," in Confluence of Cultures: French Contributions to Indo-Persian Studies, ed. Nalini Delvoye (New Delhi: Manohar, 1994), 23-36. It also featured a seven-story tower, the base of which can still be seen today.

28. Identifying the specific relationship between architectural decoration and manuscripts is beyond the scope of this study, but I examine the architecture of Mandu for possible implications for its manuscripts. For instance, the Miftăh defines and illustrates several architectural terms, such as vaulted roof (jaft, with illustration), porched doorway (kha$n u b$, with illustration), four-post/tent (chārțāq), vaulted roof of the ayvān (kham), dome (khanbah), palace (kākh), church (kanisah), honeycomb vault (muqarnas), etc. See BL Or 3299, ff. 94a; 102b; 97a; 109b; 113b; 224a; 240a; 266b.

29. Another lexicon, the Dānishnāmah-i Qadar Khān (1405) of Ashraf bin Sharaf al-Muzakkar Fārūqī, was composed in Chanderi. See Rajeev Kinra, "This Noble Science: IndoPersian Comparative Philology, ca 1000-180o," in South Asian Texts in History, ed. Yigal Bronner, Whitney Cox, and Lawrence McCrea (Ann Arbor, MI: Association for Asian Studies, 2011), 368.

30. The most thorough assessment of textual sources on Malwa remains Upendra Nath Day, Medieval Malwa: A Political and Cultural History, 1401-1562 (New Delhi: Munshi Ram Manohar Lal, 1965). Vernacular and Sanskrit sources provide companions to the Persian and Arabic archives and the manuscripts themselves, but they extend beyond the scope of this study.

31. This preface is entirely absent from the Tehran manuscript. 
32. BL Or 3299, f. 4a.

33. Ibid.

34. Bodleian MS Fraser 63, dated 1633 .

35. See BL Or 3299, f. 179b, for the illustration of the sāqu (bartender). The sāqu is a common trope from Persian poetry and led to the genre of the Sāqināmah. Folio 186a depicts Shabdiz, Khusraw's steed. The illustration of sitān, "to be hung upside down," on folio $17 \mathrm{ob}$ visually alludes to the execution of Mazdak in the Shāhnāmah. There are also several non-illustrated lemmas from the Shāhnämah.

36. BL Or 3299, f. 71 b.

37. Ibid, f. 248 b. Note that the inscription in the bottom left corner of the illustration, kavāshìr, is not a catchword. It is the lemma for the definition on the following page.

38. The pun famously appears in the quatrains of "Umar Khayyam. See, for instance, Khayyam, "Rubāî̄ number 7," Ganjoor.net, accessed January 30, 2021, <https://ganjoor. net/khayyam/robaee/sh7/.> See also Arthur John Arberry, The Romance of the Rubaiyat (London: Allen \& Unwin, 1959), 203.

39. On the idea of anticipation and play, see Fatemeh Keshavarz, "Sewn Together with the Thread of the Sun: Religion and Literature as a Discipline," Religion and Literature 41, no. 2 (2009): 39. Keshavarz's readings of Rumi emphasize his playfulness and begin to theorize this concept in the Persian sphere. See Fatemeh Keshavarz, Reading Mystical Lyric: The Case of Jalal al-Din Rumi (Columbia, SC: University of South Carolina Press, 1998), 73. We can also detect an element of play in the question (su'vāl) and answer (javāb) that completes the distich in Persian poetry competitions. Margaret Graves has recently argued that playfulness is an important mode through which artisans negotiate the relationship between architectonic objects and architecture in her book Arts of Allusion: Object, Ornament, and Architecture in Medieval Islam (Oxford: Oxford University Press, 2018), 211.

40. Elizabeth Merklinger, Sultanate Architecture of Pre-Mughal India (New Delhi: Munshiram Manoharlal, 2005), 45, 135.

41. This lexicon is now lost. See Baevskiŭ, Early Persian Lexicography, 88, and Pellò, "Local Lexis?" 171nı.

42. This is a Persian dictionary by 'Alī ibn Ahmad Asadī Ṭ̂̄sī from Khurasan (999-1072). It contains several phrases from Darī poetry and is the first known Persian dictionary.

43. The titles Mafātịh al-Fażāil (Keys of Virtues) and Sulālat al-Faża'il (Genealogy of Virtues) are similar to the Miftāh al-Fużalà', suggesting Shadiyabadi's possible preferences. It is unclear if these works should be read as two separate titles or as a single title. They may represent an alternative

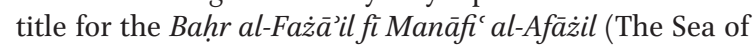
Virtues for the Benefit of Learned) compiled by Muhammad ibn Qavvām ibn Rustam ibn Aḥmad Balkhī in 1433, India. See Baevskiǔ, Early Persian Lexicography, 105-8.

44. BL Or 3299, ff. 4a-b. Pellò, "Local Lexis?" suggests that Malwa in particular was a center for the codification of farhangs. In the sultanate context, there are a total of three farhangs made in Mandu, including the Miftāh.
45. Baevskiŭ, Early Persian Lexicography, 71-77; Karomat, "Turki and Hindavi in the World of Persian," 139.

46. Baevskiü, Early Persian Lexicography, 157.

47. Fakhr al-Dīn Mubārak Shāh 'Qavvās' Ghaznavī, Farhang-i Qavvās, ed. Nazir Ahmad (Tehran: BTNK, 1974), 115-78.

48. BL Or 3299, f. 266b.

49. Hājib-i Khayrāt Rafī‘ Dihlavì's patron was Shams al-Dīn Muhammad Jajnīrī of Delhi. Baevskiū, Early Persian Lexicography, 77; Asiatic Society of Bengal MS 517; Karomat, "Turki and Hindavi in the World of Persian," 133.

50. 'Āshiq, Farhang-i Lisān al-Shu'arā', ed. Nazir Ahmad (New Delhi: Rāyzanī-yi Farhangī-yi Jumhūrī-yi Islamī-yi İrān, 1995).

51. Karomat, "Turki and Hindavi in the World of Persian," 133-34; Pellò, "Local Lexis?" 177.

52. Shihab Hakim, the author of the Traditions of Mahmud Shah (1468), is another intellectual who migrated from Jaunpur to Mandu in 1465. Shihab Hakim's nisbah suggests that he had originally migrated from Kirman. There was also a massive influx of Sufis, nobility, and intellectuals from Kirman to the Bahmani court of Bidar, a court that factors heavily in Shihab Hakim's historical account of Mandu.

53. Baevskiü, Early Persian Lexicography, 99.

54. Ibid., 179 .

55. See especially Pellò, "Local Lexis?" 182. Standalone Hindavi entries in the Miftāh problematize this, however. See BL Or 3299, f. 126b; Karomat, "Turki and Hindavi in the World of Persian," 161. Rajeev Kinra also makes a similar argument in "Cultures of Comparative Philology in the Early Modern Indo-Persian World," Philological Encounters 1 (2016): $225^{-87}$.

56. This method of organization was utilized in the Adāt al-Fużalä' (Delhi, 1419), BL Or 1262. See Karomat, "Turki and Hindavi in the World of Persian," 136. According to Baevskiǐ, these farhangs elide a chapter devoted to the letter 'ayn, most likely because 'ayn is a guttural consonant associated with Arabic and not Persian. See Baevskiĭ, Early Persian Lexicography, 153. In the absence of any contrary evidence, I follow Baevskiǐ's argument.

57. The Ni'matnāmah (BL IO Islamic 149) also uses a system of marginal tabulation. Norah Titley, The Ni'matnama Manuscript of the Sultans of Mandu: The Sultan's Book of Delights (Oxford: RoutledgeCurzon, 2005).

58. In the preface Shadiyabadi states, "most of Persian letters and letters with short vowels and diacritics have not gone unexamined" (bīshtar-i hurūf-i pārsī va i'arāb-i muhmal nāmar'ì guzāshtah nashudah ast). BL Or 3299, f. 4 b.

59. Éloïse Brac de la Perrière, "The Art of the Book in India under the Sultanates," in Orsini and Sheikh, After Timur Left, pl. 5.1. My reading accounts for $m \bar{u} h \bar{\imath}$ from the Hindi mumh, which differs from muvahī as implied by Brac de la Perrière.

6o. BL Or 3299, f. 212b.

61. Ibid., f. 73a.

62. Titley, The Ni'matnama Manuscript. It would be revealing to compare this copy of the text to a manuscript with a similar 
title commissioned by Ibrāhīm 'Adil Shāh II of Bijapur. I demonstrate several other artistic connections between the courts of Mandu and Bijapur. See Mark Zebrowski, Deccani Painting (New Delhi: Roli Books, 1983), 76-78.

63. BL IO Islamic 149, f. 10ov. The naskh calligraphy of the Nimatnāmah and the Cleveland Tütinammah are strikingly similar. The completion of the Cleveland Tüțināmah has been dated to 1570 by John Seyller based on its overpainting. The black body text is nearly identical to the Ni'matnāmah and short vowels are frequently indicated in gold. The scholarship on this manuscript has tended to consider it as a product of the early Mughal atelier, 1560-70. While it was completed in a Mughal milieu, the manuscript was likely initiated in a sultanate book workshop familiar with the Chāndāyan and Caurapañcāsikā style of painting. See John Seyller, "Overpainting in the Cleveland Țütināma," Artibus Asiae 52, no. 3 (1992): 283-318, at 308, for the problems of dating this manuscript.

64. Brac de la Perrière, "Bihârî et naskhî-dîwânî: remarques sur deux calligraphies de l'Inde des sultanats," in Ecriture, calligraphie et peinture, Studia Islamica, ed. A. L. Udovitch and H. Touati (Paris: Maisonneuve et Larose, 2003), 86-92; and Vivek Gupta, "Naskhi-divani: A Little-Recognized Sultanate Script," British Library, Asian \& African Studies Blog (o6/24/2019) <https://blogs.bl.uk/asian-and-african/2019/o6/naskhi-divani-a-little-recognized-sultanatescript.html.>

65. The manuscript JRL Hindustani MS 1 was likely produced in Mandu around 1520-30. Throughout the manuscript, the script is typically naskhì-dìvanni. See, for example, f. 134b. There are cases in which the script of the sultanate Chāndāyans comes closer to a Bihari, but it is still a naskhi dìvāni script. Take, for instance, the thicker and more widely spaced text of the Varanasi Chāndāyan. See Anand Krishna, "An Illustrated Manuscript of the Laur-Chanda in the Staatsbibliothek, Berlin," Chhavi 2: Rai Krishnadasa Felicitation Volume (1981): 275-89. This is also reproduced in Adamjee, "Strategies for Visual Narration," pl. 2.26.

66. BL Or 3299, f. 4 b.

67. Majlis Library IR-10-37320, f. 121a, contains the chapter heading al-Yä' $m a^{\prime}$ al-Alif, which is precisely the text one would expect on folio 296a of BL Or 3299.

68. Robert Skelton, "The Ni'matnama: A Landmark in Malwa Painting," Marg 12, no. 3 (1959): 48; Brend, Perspectives on Persian Painting, 86. For an outline of this style, see B. W. Robinson, "The Turkman School to 1503," in The Arts of the Book of Central Asia $14^{\text {th }}-16^{\text {th }}$ centuries, ed. Basil Gray (Paris: UNESCO, 1979), 244-45. Recently, David Roxburgh and Simon Rettig have offered reconsiderations of this category of illustrated books. See David J. Roxburgh, "Many a Wish Has Turned to Dust': Pir Budaq and the Formation of Turkmen Arts of the Book," in Envisioning Islamic Art and Architecture: Essays in Honor of Renata Holod, ed. David J. Roxburgh (Leiden: Brill, 2014), 175-222; and Simon Rettig, "La production manuscrite à Chiraz sous les Aq Qoyyunlu entre 1467 et 1503" (PhD diss., Université Aix-Marseille I, Université de Provence, 2011). See also Priscilla Soucek,
“The New York Public Library 'Makhzan al-asrār' and Its Importance," Ars Orientalis 18 (1988): 1-37.

69. Robinson, Fifteenth-Century Persian Painting, 31. See also Norihito Hayashi, "The Turkman Commercial Style of Painting," Orient 47 (2012): 169-9o, for a recent assessment of this category. John Woods, The Aqquyunlu: Clan, Confederation, Empire, rev. ed. (Salt Lake City, UT: University of Utah Press, 1999) is an important history of the empire.

70. Robinson, "Turkman School to $1503, " 244$.

71. There is scant evidence of a possible Mandu artist named Hajji Mahmud, who may have been responsible for several illustrations and the illumination in the Nimatnāmah (fig. 16) and Būstān (The Orchard) (1502-3). See Richard Ettinghausen, "The Bustan Manuscript of Sultan Nasir Shah Khalji," Marg 12, no. 3 (1959): 40-43; Stuart Cary Welch, India, Art and Culture (New York: Metropolitan Museum of Art, 1985), 133-35. V\&A IS.14-1958 is a single-page drawing signed by this artist. Considering the style of the Büstān paintings, it appears Hajji Mahmud may have trained in a Timurid or Turkmen atelier before migrating to India. The Ni'matnāmah, however, has Turkmen elements, suggesting that the artist was able to work in a variety of painting practices. The few published illustrations of this Būstān are more Timurid than the decidedly Turkmen style we observe in the Miftăh. It thus seems that Mandu attracted a range of artists trained in various styles of Persian painting. While the Miftāh is more or less uniform in the style of its paintings, it does not stand for all of Mandu's manuscripts.

72. Bodleian Library MS Elliot 246, f. 25b, following B. W. Robinson, A Descriptive Catalogue of Persian Paintings in the Bodleian Library (Oxford: Clarendon Press, 1958), pl. 501 for this thicket. Although attributed to Timurid Herat, the illustrations to the Shāhnāmah (Chester Beatty Library Per 157) also bear some striking resemblances to BL Or 3299.

73. BL Or 3299, f. 278 b (top illustration); IO Islamic 149, f. 100 b. 74. The bottom illustration of BL Or 3299 , f. 161 b features this type of background.

75. Ibid., f. $92 b$.

76. Bodleian MS 325, f. 328a. Robert Skelton also cites this Shāhnamah in highlighting features of the commercial Turkmen style. See Skelton, "Ni'matnama."

77. Royal Asiatic Society MS Pers 178 (Persian Wonders of Creation, Shiraz, 1475) shares a similar golden skyline, with a background of primarily green flowers against a pale blue ground. See B. W. Robinson, "R. A. S. MS 178: An Unrecorded Persian Painter," Journal of the Royal Asiatic Society 2 (1970):15-23. In addition, a "Timurid" Wonders of Creation, Museum of Islamic Art, Doha, 2014.455, also shares several stylistic features with BL Or 3299. See Gupta, "Wonder Reoriented," for further discussion.

78. Brac de la Perrière, "Art of the Book in India," 310. The Injuid archaisms in sultanate manuscripts extended far beyond the fifteenth century as well. See Gupta, "Wonder Reoriented," 134, for a discussion of the 'Adil Shahi translation of Qazvini's cosmography. The many copies of this manuscript from the mid-sixteenth century onwards appear to be copied from an Injuid cycle of illustrations. 
79. Ali Anooshahr, "Shirazi Scholars and the Political Culture of the Sixteenth-Century Indo-Persian World," Indian Economic Social History Review 51 (2014): 336. See Keelan Overton, "Book Culture, Royal Libraries, and Persianate Painting in Bijapur, circa 1580-1630," Muqarnas 33 (2016): 91-154, for an overview of Mahmud Gavan's library; and Vivek Gupta, "Remapping the World in a Fifteenth-Century Cosmography: Genres and Networks Between Deccan India and Iran," Iran:Journal of the British Intitute of Persian Studies 59, no. 2 (2021), for the discovery of a fifteenthcentury cosmography that likely passed through Gavan's library. See Maya Petrovich, "Merchants, Young Heroes and Caliphs: Revisiting Maḥmūd Gāwān," in Turkish History and Culture in India: Identity, Art and Transregional Connections, ed. A. C. S. Peacock and Richard Piran McClary (Leiden: Brill, 202O), 104-28; Simon Rettig, "A 'Timurid-Like Response' to the Qur'an of Gwalior?: Manuscript $W_{5} 63$ at the Walters Art Museum, Baltimore," in Le coran de Gwalior. Polysémie d'un manuscript à peintures, ed. Éloïse Brac de la Perrière and Monique Burési (Paris: PUPS, 2016), 203, and Gülru Necipoğlu, "The Spatial Organization of Knowledge in the Ottoman Palace Library: An Encyclopedic Collection and Its Inventory," in Treasures of Knowledge: An Inventory of the Ottoman Palace Library (1502/3-1503/4), ed. Gülru Necipoğlu, Cemal Kafadar, and Cornell H. Fleisher (Leiden: Brill, 2019), 43, for flows between the early Ottoman world and Gavan's library. Less is known about the libraries of Gujarat.

8o. The chapters in Keelan Overton, ed., Iran and the Deccan: Persianate Art, Culture, and Talent in Circulation, c. 14001700 (Bloomington, IN: Indiana University Press, 2020) have advanced scholarship on these networks.

81. Assadullah Souren Melikian-Chirvani was a pioneer of this subject. See "L'école de Shiraz et les origines de la miniature moghole," in Paintings from Islamic Lands, ed. Ralph Pinder-Wilson (Columbia, SC: University of South Carolina Press, 1969), 124-41.

82. It is important to note that early scholars of Persian painting identified a childlike quality in the style of such images, particularly from the fifteenth century. David J. Roxburgh analyzes the issues with these earlier comments in "Micrographia: Toward a Visual Logic of Persianate Painting," RES: Anthropology and Aesthetics 43 (2003): 13 and footnote 7.

83. We may begin to reconstruct a social history of upbringing in the Indo-Islamicate world by looking at how princes were raised and cultivated. See Munis D. Faruqui, The Princes of the Mughal Empire, 1504-1719 (Cambridge: Cambridge University Press, 2012), 66-133.

84. BL Or 3299, ff. 51b and 259b, 55b and 212b, 217a, 22ob, $291 \mathrm{a}$.

85. It would be instructive to consider these definitions of dolls within a longer history. Fatimid dolls may be one group of objects to investigate in relation to this question. See Alzahraa K. Ahmed, "Refiguring Figurines: Amulets/Dolls in the Eastern Mediterranean (Sixth-Twelfth Century)," Met Fellows Colloquium-Arts of Memory and Image Making from Asia to the Mediterranean (Metropolitan Museum of Art, New York, April 28, 2017).
86. BL Or 3299 , f. 278 b. The closest comparison I have identified for the bottom illustration is from a detached folio of a dìvān by the poet Hafiz that shows Layla and Majnun at school. This painting is attributed to Shiraz, 1490, and is in the Sackler Gallery (S1986.289).

87. The word for teacher, or āmūzgār, is also an entry in the dictionary (ibid., f. 13a). The herd here alludes to the illustrated definition of ramah on folio 139b. Two other closely related illustrations are the herd of cows and wild asses (kavbārah, f. 244a), and the child of a horse, or foal (karah, f. 244a).

88. BL Or 3299, ff. 101b, 216b, f. 103b, f. 244a. It also provides the definition of a herd of cows and wild asses on f. 244a, which fits with the theme of animals following a leader.

89. BL Or 3299, f. 286 a.

9o. BL Or 3299 , ff. 143 b, 228 b.

91. See Gupta, "Wonder Reoriented," 201-57 for an analysis of this manuscript.

92. I refer to the title of Matthew Saba's "Abbasid Lusterware and the Aesthetics of 'Ajab," Muqarnas 29 (2012): 187-212, as it has influenced my approach to this subject and factors into the following paragraphs. See Travis Zadeh, "The Wiles of Creation: Philosophy, Fiction, and the 'Ajā'ib Tradition," Middle Eastern Literatures 13, no. 1 (2010): 29-30, for the link between wonder and pleasure; and Gupta, "Wonder Reoriented," 27-32.

93. Oya Pancaroğlu, "Signs in the Horizons: Concepts of Image and Boundary in a Medieval Persian Cosmography," RES: Anthropology and Aesthetics 43 (2003): 34.

94. Persis Berlekamp, Wonder, Image, and Cosmos in Medieval Islam (New Haven, CT: Yale University Press, 2011).

95. BL Or 3299, f. 8ob. For discussions of the takük, see Graves, Arts of Allusion, 61; Assadullah Souren Melikian-Chirvani, "Le rhyton selon les sources Persanes," Studia Iranica 2 (1982): 276; and Assadullah Souren Melikian-Chirvani, "Les taureaux à vin et les cornes à boire de l'Iran islamique," in Histoire et cultes de l'Asie central préislamique, ed. Paul Bernard and Frantz Grenet (Paris: Éditions du centre nationale de la recherche scientifique, 1991), 102-4. Melanie Gibson's "Takūk and Timthāl: A Study of Glazed Ceramic Sculpture from Iran and Syria circa 1150-1250" (PhD diss., SOAS University of London, 2010) is a definitive study of the takūk.

96. Mark Zebrowski defines surahi as a "tall elegant flask for wine or water." See Mark Zebrowski, Gold, Silver and Bronze from Mughal India (London: Alexandria Press in association with Laurence King, 1997), 17.

97. The word also appears in the eleventh-century Lughat- $i$ Furs of Asadī Țūsī, the first known Persian lexicon.

98. Qavvās, Farhang-i Qavvās, 134-43.

99. Majlis Library IR-10-37320, f. 26a. The definition continues on folio $26 \mathrm{~b}$ where we find the statement, "In other copies [baciż nuskhah] it is written as takrak." This implies that there may have been other copies of the Miftăh or related lexicons available to the scribe.

10o. Ali Akbar Dehkhuda, Lughatnāmah-i Dihkhudā <https:// www.vajehyab.com/dehkhoda/تكوك (accessed April 2, 2018). 
101. This is a case in which a recognizable depiction sheds light on the textual definition. See Gupta, "Interpreting the Eye ('ain)," 195-97, for my thoughts on what constitutes a recognizable depiction.

102. Zebrowski, Gold, Silver and Bronze, 99, fig. 101.

103. BL Or 3299, ff. 8oa-b; 8ob; and, 81b.

104. Ibid., f. 8 oa.

105. Assadullah Souren Melikian-Chirvani, "Le rhyton selon les sources Persanes," Studia Iranica 2 (1982): 263-92; Gibson, "Takūk and Timthāl."

106. Gibson, "Takūk and Timthāl," vol. 2, 135, cat. 392. I thank Melanie Gibson for sharing this with me. See also Assadullah Souren Melikian-Chirvani, "The Wine-Birds of Iran from Pre-Achaemenid to Islamic Times," Bulletin of the Asia Institute 9 (1995): 81-87. Deciphered by Melikian-Chirvani, its inscriptions are Sufi in nature and contain verses of Hafiz and Nizami.

107. Katherine Kasdorf, "Forming Dōrasamudra: Temples of the Hoysala Capital in Context" (PhD diss., Columbia University, 2013), fig. $5 \cdot 31$.

108. Zebrowski, Gold, Silver and Bronze, 99, figs. 98-101. See also ibid., figure 3.16 for an example of a spiral fluted decanter similar in type to plates $189-90$.

109. Phillip Wagoner and Laura Weinstein, "The Deccani Sultanates and Their Interregional Connections," in A Companion to Islamic Art and Architecture, ed. Finbarr Barry Flood and Gülru Necipoğlu (Hoboken: Wiley Blackwell, 2017), 798-99, makes this point. A project I initiated in 2014 on the Bijapuri monumental cannon known as the Malik-i Maydān also considered this issue. See Vivek Gupta, "Art and Artillery: The Iconography of the Malik-i Maydān," Lecture, Jnanapravaha Series in Islamic Art, Mumbai, India, January 6, 2017.

110. Zebrowski, Gold, Silver and Bronze, 100, figs. 103-5.

111. To balance this interpretation of the takūk, it is worth emphasizing here that all crafts defined within the Miftăh cannot be considered wonders. Shadiyabadi provides many definitions with pragmatic purposes. One example is the illustration of the kamās, which is a bottle meant to be worn, with a covering that is sometimes made of wood, sometimes of earthenware; it can also be carried in the armpit. BL Or 3299, f. 229 .

112. BL Or 3299, f. 95b.

113. Ibid., ff. 95a-b.

114. Qavvās, Farhang-i Qavvās, 49.

115. BL Or 3299, f. 146b.

116. Extant shoes of this type survive, but they are made out of gilt steel with overlay (kuftagarì). See Howard Ricketts, "122. Armored Shoes," in Sultans of Deccan India, 1500-1700, ed. Navina Najat Haidar and Marika Sardar (New Haven, CT: Yale University Press, 2015), 230-31.

117. BL Or 3299, f. 106a. Another non-illustrated shoe is the sandal on $\mathrm{f} .167 \mathrm{a}$.

118. Saba, "Abbasid Lusterware and the Aesthetics of 'Ajab," 193-95.

119. Ibid., 192-93.

120. Sa'dī of Shiraz, Gulistān, trans. Wheeler M. Thackston (Bethesda, MD: Ibex Publishers, 2008), 7.
121. Qavvās, Farhang-i Qavvās, 152.

122. Babur, Emperor of Hindustan, 1483-1530, Bāburnāmah, trans. Wheeler M. Thackston (Washington, DC: Freer Gallery of Art, Smithsonian Institution, 1996), 340.

123. Chester Beatty Library In o9, f. 3 b (Mughal, 1650); BL Add 15241, f. 1b (Aurangabad, 1698); Salar Jung Museum Library Geo MS 12 (Hyderabad? ca. 170o?).

124. Ghulām 'Alī “Āzād” Bilgrāmī, Subhat al-marjān fì àthār Hindūstān (Aligarh:Jāmi'at 'Alīgarh al-Islāmiyya, 1976-8o), 2:239. As a noun in Persian, the word can also mean a chameleon or turkey. A full discussion of Azad's definition of būqalamūn is provided in Vivek Gupta, "The Voice of the Indian Cuckoo in Arabic: The Adaptive Capacity of Ghulām 'Alī 'Āzād' Bilgrāmī's Poetics in the Eighteenth Century," Journal of South Asian Intellectual History (forthcoming).

125. Ghulām 'Alī "Āzād" Bilgrāmī, Subhat al-marjān fì àthār Hindūstān (Aligarh:Jāmi'at 'Alīgarh al-Islāmiyya, 1976-8o), 2:239.

126. BL Or 3299, f. 189 a.

127. Ibid. This bird also appears in Qazvini; see BL Or 4701, f. 213a.

128. Ali Akbar Dehkhuda, Lughatnāmah-i Dihkhudā <https:// www.vajehyab.com/dehkhoda/شوالك>> (accessed April 2, 2018).

129. It is curious that Shadiyabadi chooses not to provide a definition of büqalamūn, given his penchant for wonder. The textile meaning of büqalamūn does appear in the Farhang- $i$ Qavvās, 152 .

13o. BL Or 3299, ff. 100a, 126b and 259b, 240a, 272a, 262a, 133 b.

131. See the sagak (ibid., f. 166b) and dīzan (ibid., f. 125b).

132. Stewart Gordon, "Burhanpur: Entrepôt and Hinterland, 1650-1750," The Indian Economic and Social History Review 25, no. 4 (1988): 425-42; Vivek Gupta, "Splendour of the City, Nagarshobha: Textile Culture of Mughal Burhanpur," in Reflections on Mughal Art and Culture, ed. Roda Ahluwalia (New Delhi: Niyogi Books, 2020), 229-53.

133. BL Or 3299, f. 93b. Similar images of yogis appear in the Chāndāyan. See the illustration of "The Second Day: The Arrival of the Snake Charmer and Laurak Falls at His Feet," John Rylands Library, Hindustani MS 1, f. 27oa. For descriptions of yogic attire in contemporaneous vernacular sources, see James Mallinson, "Nath Yogis and Their 'Amazing Apparel' in Early Material and Textual Sources" (forthcoming).

134. BL Or 3299, f. 116b. The definition also appears in Majlis Library IR-10-37320, f. 40a, and in the Farhang-i Qavvās in a chapter devoted to the names of birds, reptiles, and anything that moves, which is lodged within a section that defines the names of men and human figures (Qavvās, Farhang-i Qavvās, 77).

135. Francis Joseph Steingass, A Comprehensive Persian-English Dictionary, Including the Arabic Words and Phrases to Be Met with in Persian Literature (London: Routledge \& K. Paul, 1892), 566.

136. BL Or 3299, f. 223b. Qavvās defines kakh as a beast that frightens children: Farhang-i Qavvās, 114.

137. BL Or 3299, f. 111a. The definition of khujivan is also an illustrated definition of a $d \bar{\imath} v$; however, the image does not show a child. 
138. David J. Roxburgh, The Persian Album, 140o-16oo: From Collection to Dispersal (New Haven, CT: Yale University Press: 2005).

139. David J. Roxburgh, "The Aesthetics of Aggregation: Persian
Anthologies of the Fifteenth Century," Princeton Papers: Interdisciplinary Journal of Middle Eastern Studies (2001): 123. I thank Christiane Gruber for discussing the term vade mecum with me.

\section{TABLE OF PAINTINGS IN THE MIFTĀH $A L-F U \dot{Z} A L \bar{A}^{\prime}$, BRITISH LIBRARY OR 3299}

1. Entry or lemma name in Persian transliteration. Indic words are provided if they appear within the definition. Note: there are no illustrated Hindi entries/lemmas.

2. Folio number of painting.

3. Identification of painting. If multiple meanings of a single word are illustrated, the identification is indicated with an asterisk.

4. Measurements of the illustrations given as length $\times$ width in centimeters.

In cases where the illustration is of an irregular shape, I provide top/bottom (length) $\times$ left/right (width).

\begin{tabular}{|c|c|c|c|}
\hline $\begin{array}{l}\text { 1. Lemma in Persian and any } \\
\text { given Indic equivalents }\end{array}$ & 2. Folio of illustration & 3. Depicted definition & $\begin{array}{l}\text { 4. Dimensions } \\
(\mathrm{L} \times \mathrm{W} \mathrm{cm})\end{array}$ \\
\hline bādjan & $5^{1 b}$ & doll & $5.9 \times 6.8$ \\
\hline bādafarah; Ind: latțū & $55^{b}$ & whiptop & $6.2 \times 6.5$ \\
\hline badrīsah & $56 a$ & tent-pole & $6.1 \times 7.2$ \\
\hline bākhah & $56 b$ & turtle & $4.1 \times 6.8$ \\
\hline bārbad & 6 oa & name of Khusraw's musician & $8.2 \times 9.3$ \\
\hline pālād & $6 o b$ & horse & $6.3 \times 7.2$ \\
\hline parandā & $61 \mathrm{~b}$ & sword & $6.2 / 3.2 \times 7.2 / 5.9$ \\
\hline paghāz & $62 a$ & wedge & $6.4 \times 4.8$ \\
\hline pāsuk & $65^{a}$ & to yawn & $5.6 \times 6.4$ \\
\hline pushk & $65 \mathrm{~b}$ & goat & $4 \times 5.2$ \\
\hline panjpāyak & $66 a$ & crab & $4.6 \times 3.9$ \\
\hline palang & $66 b$ & cheetah & $5.6 \times 5.6$ \\
\hline pālāvan & $67 \mathrm{~b}$ & mace & $2 \times 8$ \\
\hline pālvāyah & $7 \mathrm{ob}$ & black and white bird, the swallow & $4.4 \times 5.2$ \\
\hline pālvānah & $7 \mathrm{ob}$ & ladder & $4 \times 2.5$ \\
\hline parvānah & $71 \mathrm{~b}$ & moth & $5.8 \times 4.2$ \\
\hline parah & $72 \mathrm{a}$ & gathering of the troops; dried branches* & $10.8 \times 12.1$ \\
\hline pahanānah & $73 \mathrm{a}$ & monkey, ape & $5.8 / 4.4 \times 5.1 / 4.2$ \\
\hline tarandak; Ind: mammolā & 8 oa & wagtail & $4.2 \times 3$ \\
\hline takūk & $8 o b$ & zoomorphic vessel & $7.8 \times 7.9$ \\
\hline tūrang & $81 \mathrm{~b}$ & partridge & $4.1 \times 3.8$ \\
\hline tanbān & $82 b$ & short linen drawers & $5 \times 6.6$ \\
\hline tardah & $84 \mathrm{~b}$ & device to ease a hand-mill & $5.8 \times 5.9$ \\
\hline tūrah & $85^{b}$ & jackal & $7.2 \times 5.6$ \\
\hline $\operatorname{tash} \bar{\imath}$ & $86 a$ & porcupine & $2.8 \times 3.9$ (no ruling) \\
\hline jūj & $87 \mathrm{~b}$ & the red part of a rooster's plume & $4.1 \times 4.1$ \\
\hline javāz; Ind: $u k h l \bar{\imath}$ & $89 a$ & mortar & $4.1 \times 7 \cdot 3$ \\
\hline jaq & $89 b$ & $\begin{array}{l}\text { alternative spelling for jak, meaning "to } \\
\text { churn" milk }\end{array}$ & $6.4 \times 6.3$ \\
\hline$j \bar{u} q$ & 9oa & group or army & $5.6 \times 8.8$ \\
\hline jangalūk & 9ob & weak person in recovery & $5.9 \times 6.2$ \\
\hline jīdān & $91 b$ & $\begin{array}{l}\text { seasame }(\text { kunjud }) \text { or the jujube tree } \\
(\text { sinjid })^{*}\end{array}$ & $4.1 \times 7.8$ \\
\hline jullah & $92 b$ & plant, mushroom & $5 \cdot 7 \times 5 \cdot 3$ \\
\hline chūkhā & $93 \mathrm{~b}$ & robe worn by yogis & $6.1 \times 6.1$ \\
\hline
\end{tabular}


TABLE OF PAINTINGS IN THE MIFTĀH AL-FUŻALĀ', BRITISH LIBRARY OR 3299 (Cont.)

\begin{tabular}{|c|c|c|c|}
\hline $\begin{array}{l}\text { 1. Lemma in Persian and any } \\
\text { given Indic equivalents }\end{array}$ & 2. Folio of illustration & 3. Depicted definition & $\begin{array}{l}\text { 4. Dimensions } \\
(\mathrm{L} \times \mathrm{W} \mathrm{cm})\end{array}$ \\
\hline chazkhusht & $93 \mathrm{~b}$ & winepress & $6.1 \times 6.6$ \\
\hline jaft & $94 a$ & vaulted roof & $8.6 \times 5$ \\
\hline chapdār & $95^{b}$ & boot stocking & $8.2 \times 6.1$ \\
\hline jazr & $96 a$ & red bird & $6 \times 5 \cdot 3$ \\
\hline jakhash & $96 b$ & goiter (a kind of illness) & $7.8 \times 5 \cdot 5$ \\
\hline chaghük; Ind: matrah or jaftak & $97 \mathrm{~b}$ & sparrow or lark & $4.1 \times 5.9$ \\
\hline chang & $98 b$ & stringed instrument & $8.1 \times 11.9$ \\
\hline chūblìn & $100 a$ & tool for separating cotton from its pod & $6.6 \times 6.6$ \\
\hline chārpārah & $100 b$ & castanets & $6.5 \times 6.1$ \\
\hline chaghānah & $101 \mathrm{a}$ & stringed instrument similar to the $r u b \bar{a} b$ & $7.9 \times 6.6$ \\
\hline chūzhah & $101 \mathrm{~b}$ & chicklets & $6.2 \times 6.3$ \\
\hline khanub & $102 b$ & porched doorway & $8.3 \times 7.5$ \\
\hline khüch & $103 \mathrm{~b}$ & a tame ram used by children & $8 \times 7.9$ \\
\hline khushkāmār & $104 \mathrm{~b}$ & oedema (illness) & $6 \times 11.9$ \\
\hline kharī̄āz / kharbīvāz & $105 \mathrm{~b}$ & large bat & $7 \cdot 9 \times 7 \cdot 3$ \\
\hline khabazdūk & $107 \mathrm{~b}$ & beetle & $4 \times 5$ \\
\hline khumak & $108 \mathrm{a}$ & hand-drum or tambourine & $4.3 \times 5.6$ \\
\hline kharchang & $108 \mathrm{~b}$ & crab & $2.2 / 5.8 \times 4.8 / 4$ \\
\hline khujīvan & $111 \mathrm{a}$ & a type of demon & $2.1 / 6.3 \times 2.8 / 1.2$ \\
\hline kharūh & $112 \mathrm{~b}$ & decoy, or trap for birds & $1.8 / 5.8 \times 8 / 4$ \\
\hline$d \bar{v}$-kulūch & $116 b$ & child possessed by a demon & $8.2 \times 12$ \\
\hline dukhtarnadar & $118 \mathrm{a}$ & step-daughter & $6.3 \times 6.5$ \\
\hline dastās & $119 \mathrm{a}$ & handmill for corn grinding & $5.9 \times 7$ \\
\hline darfash & $119 \mathrm{a}$ & flag & $6.4 \times 6.8$ \\
\hline daryūsh & $119 b$ & dragon & $7.9 \times 5.8$ \\
\hline durdaksh & $120 \mathrm{a}$ & drunkard & $8 \times 6.6$ \\
\hline dangal & $122 \mathrm{a}$ & idiot & $6.5 \times 6.3$ \\
\hline dām & $122 \mathrm{~b}$ & snare & $8.3 \times 12$ \\
\hline dūzah; Ind: sarvālih & $125 \mathrm{~b}$ & thorny plant used for making textiles & $8.4 \times 5.4$ \\
\hline durūnah & $126 b$ & bow used by a cotton dresser & $6.3 \times 8$ \\
\hline durrājah & $127 \mathrm{~b}$ & a chest used for mining pearls & $7.7 \times 5.6$ \\
\hline dum lābah & $128 \mathrm{a}$ & tail-wagging & $7.2 \times 5$ \\
\hline dallah & $128 \mathrm{a}$ & large cat & $5.8 \times 6$ \\
\hline dadah & $129 \mathrm{a}$ & wild animals & $8.8 \times 6.4$ \\
\hline rāmishgar & $132 b$ & musician & $6 \times 8.1$ \\
\hline rangriz & $133 b$ & dyer & $10 \times 7 \cdot 7$ \\
\hline razm & $136 a$ & battle & $8.7 \times 12$ \\
\hline rāsū; Ind: nūl, nakul & $138 \mathrm{a}$ & mongoose & $3.9 \times 4.4$ \\
\hline ramah & $139 b$ & flock & $1.8 / 4.1 \times 6.6 / 5.5$ \\
\hline zimunj & $142 b$ & black predatory bird & $4.3 \times 5$ \\
\hline$z \bar{a} d$ & $143 b$ & son & $6.1 \times 7.8$ \\
\hline ziyād & $144 a$ & a move in backgammon & $2.2 / 6 \times 7.9 / 4.1$ \\
\hline$z a v \bar{a} r$ & $144 \mathrm{~b}$ & slave & $5.6 \times 7.9$ \\
\hline zanjīr; Ind: brūtha (unattested) & $145^{a}$ & chain & $8 \times 12$ \\
\hline zigar & $145 \mathrm{~b}$ & $\begin{array}{l}\text { striking the cheeks when they are full of } \\
\text { air }\end{array}$ & $6.3 \times 6.7$ \\
\hline zarīnah kafsh & $146 b$ & golden shoes & $6.2 \times 12$ \\
\hline zabūn & $149 \mathrm{~b}$ & $\begin{array}{l}\text { she-camel who kicks her milker, or a } \\
\text { captive }\end{array}$ & $8.5 \times 8.4$ \\
\hline
\end{tabular}


TABLE OF PAINTINGS IN THE MIFTĀH AL-FUŻALA', BRITISH LIBRARY OR 3299 (Cont.)

\begin{tabular}{|c|c|c|c|}
\hline $\begin{array}{l}\text { 1. Lemma in Persian and any } \\
\text { given Indic equivalents }\end{array}$ & 2. Folio of illustration & 3. Depicted definition & $\begin{array}{l}\text { 4. Dimensions } \\
(\mathrm{L} \times \mathrm{W} \mathrm{cm})\end{array}$ \\
\hline zahdān & 15 oa & the womb & $8 \times 6.9$ \\
\hline zaghūnah & $151 \mathrm{a}$ & raw silk for a spindle & $6.2 \times 7.1$ \\
\hline zarrāfah & $15^{2 a}$ & giraffe & $7.7 \times 7.2$ \\
\hline sangpusht & $156 a$ & turtle & $4.5 \times 12$ \\
\hline sanj & $157 \mathrm{a}$ & cymbals & $6.5 \times 7$ \\
\hline sarghūj; Ind: gūnchī & $157 \mathrm{~b}$ & $\begin{array}{l}\text { head-covering for a woman } \\
\text { a green film on the surface of stagnant }\end{array}$ & $6.1 \times 7$ \\
\hline sābūd & $158 b$ & water $(\mathrm{n})$. & diam: 8.4 \\
\hline sughur & $16 o b$ & porcupine & $8 \times 8.6$ \\
\hline suftahgar & $161 \mathrm{~b}$ & stone drill & $6 \times 7 \cdot 3$ \\
\hline sanqur & $162 \mathrm{a}$ & falcon, a kind of bird that hunts & $8.6 \times 7 \cdot 3$ \\
\hline subūs & $163 b$ & one who boasts & $7.8 \times 7.8$ \\
\hline sitāragh & $164 \mathrm{~b}$ & a milk-giving animal & $6.1 \times 7.7$ \\
\hline sagak & $166 \mathrm{~b}$ & a kind of plant used to make cloth & $5.9 \times 6.3$ \\
\hline sitān & $17 \mathrm{ob}$ & to be hung upside down & $6.1 \times 6.1$ \\
\hline sirkīzìdan & $171 \mathrm{a}$ & to gallop & $3.5 / 4.2 \times 7.3 / .9$ \\
\hline sarv & $172 b$ & cypress tree & $8 \times 3.8$ \\
\hline sabūsah & $175^{a}$ & lice or dandruff? & $5.9 \times 6.8$ \\
\hline sadpāyah; Ind: kānkhajūrah & $175 \mathrm{~b}$ & centipede & $5.9 \times 6.8$ \\
\hline sanah & $176 b$ & neighing (of a horse) & $7.6 \times 8.7$ \\
\hline$s \bar{q} q \bar{\imath}$ & $179 a$ & the bartender & $8 \times 12$ \\
\hline & & a move in backgammon akin to check- & \\
\hline shashdar & $184 a$ & mate in chess & $6 \times 9 \cdot 3$ \\
\hline shaypūr & $184 \mathrm{~b}$ & Turkish horn & $6.5 \times 12$ \\
\hline shādkhvār & $185^{a}$ & one who drinks and is fresh-faced & $6 \times 6.6$ \\
\hline shabdīz & $186 a$ & Khusraw's steed & $7.8 \times 12$ \\
\hline shagh & $187 \mathrm{a}$ & horns of the cows or oxen & $7.5 \times 12$ \\
\hline shuturmurgh & $187 \mathrm{~b}$ & ostrich & $5.8 \times 7.8$ \\
\hline shavālak & $189 a$ & bustard, a bird that changes color & $4.7 \times 6.8$ \\
\hline shahlang, shāhlang & $190 a$ & rope twisting & $7.6 \times 12$ \\
\hline & & plate of steel through which gold and & \\
\hline shafshāhang & $19 o b$ & silver wire is drawn & $6.2 \times 12$ \\
\hline sharzah & $196 a$ & predatory lion & $6 \times 7 \cdot 5$ \\
\hline shikārī & $197 \mathrm{~b}$ & hunting & $10.2 \times 12 ; 1.7 / 8.5 \times 8.3 / 3.7$ \\
\hline & & a den of wild animals (n. in illustration); & \\
\hline ghāb & $198 b$ & useless (adj. not illustrated) & $9.8 \times 12$ \\
\hline ghar & 199a & filling the mouth with air so air escapes & $7.4 \times 5.2$ \\
\hline ghazāl & $201 \mathrm{a}$ & deer, gazelles & $5.4 \times 12$ \\
\hline ghurm; Ind: iyad & $201 b$ & mountain sheep & $7.2 \times 12$ \\
\hline fanj & $206 \mathrm{~b}$ & man with large testicles; ugly* & $6.5 \times 6.8$ \\
\hline farmū $k$; Ind: latțū & $212 b$ & whiptop & $7.6 \times 7.6$ \\
\hline furūjah & $216 b$ & chick & $6.4 \times 6.2$ \\
\hline farfarah & $217 \mathrm{a}$ & diablo, top & $6.1 \times 5.6$ \\
\hline kurdatā & $218 a$ & something to roast & $4.8 \times 5.7$ \\
\hline kaddā; Ind: katța (cutting) & $218 b$ & barber & $5.4 \times 12$ \\
\hline kabast & $220 \mathrm{a}$ & colocynth, bitter melon, or watermelon & $6 \times 7 \cdot 9$ \\
\hline kūrasht; Ind: danḍā-mūhì & $22 \mathrm{ob}$ & hobbyhorse & $5.7 \times 12$ \\
\hline kakhjhandah & $223 b$ & demon & $7 \cdot 3 \times 12$ \\
\hline
\end{tabular}


TABLE OF PAINTINGS IN THE MIFTĀH AL-FUŻ $A L \bar{A}$ ', BRITISH LIBRARY OR 3299 (Cont.)

\begin{tabular}{|c|c|c|c|}
\hline $\begin{array}{l}\text { 1. Lemma in Persian and any } \\
\text { given Indic equivalents }\end{array}$ & 2. Folio of illustration & 3. Depicted definition & $\begin{array}{l}\text { 4. Dimensions } \\
(\mathrm{L} \times \mathrm{W} \mathrm{cm})\end{array}$ \\
\hline kïrakh & $223 b$ & bookstand & $6.1 \times 7$ \\
\hline kuhbud & $224 a$ & mountain-dweller, ascetic & $8.1 \times 12$ \\
\hline $\begin{array}{l}\text { kuftār; Ind:jarakah?, charakah? } \\
\quad \text { (unattested) }\end{array}$ & $226 b$ & $\begin{array}{l}\text { hyena } \\
\text { child who mixes languages, cannot fully }\end{array}$ & $6.9 \times 6.2$ \\
\hline kazhmazh & $228 b$ & speak & $5.9 \times 7.9$ \\
\hline kamās & $229 \mathrm{a}$ & portable vessel, pilgrim flask & $6.4 \times 3.9$ \\
\hline kāvish & $231 \mathrm{a}$ & debate and discussion & $6 \times 12$ \\
\hline kashaf & $232 \mathrm{a}$ & tortoise & $5.6 \times 5 \cdot 3$ \\
\hline kunām & $235 \mathrm{~b}$ & wild animal's den & $7.6 \times 12$ \\
\hline kapān & $237 \mathrm{~b}$ & balance, steelyard & $7 \cdot 9 \times 7$ \\
\hline kargadān; Ind: gaimrāā & $238 \mathrm{a}$ & rhinoceros & $6.3 \times 12$ \\
\hline \multicolumn{4}{|l|}{ kulālah; Ind: mīnhirī(?) } \\
\hline (unattested) & $239 b$ & ringlets, locks & $8 \times 7.8$ \\
\hline kalābah; Ind: paretī & $240 \mathrm{a}$ & reel for winding thread on, bobbin & $6.3 \times 6.7$ \\
\hline kamānah & $240 a$ & bow for digging wells & $4.1 \times 7$ \\
\hline kamān girauha and kamān & & $\begin{array}{l}\text { a stone or something to lodge into a bow; } \\
\text { hoopoe (illustration may recall the }\end{array}$ & \\
\hline muhrah / kawkalah & $240 \mathrm{~b}$ & bird $)^{*}$ & $8 \times 7.1$ \\
\hline kallah with kulbah & $242 \mathrm{a}$ & $\begin{array}{l}\text { pleasure-place with canopy (second } \\
\text { definition on f.241b) }\end{array}$ & $\begin{array}{l}16.2 \times 12 \text { (box); } 4.7 \times 3.6 \\
\text { (upper canopy) }\end{array}$ \\
\hline karbāsah & $243 b$ & a green lizard & $3.9 \times 5.2$ \\
\hline karah & $244 a$ & foal & $7.5 \times 5.6$ \\
\hline kavbārah & $244 a$ & flock of cows and wild asses & $6.2 \times 6.5$ \\
\hline kāzah kāshah & $244 \mathrm{~b}$ & $\begin{array}{l}\text { trap made of tree branches, likely for birds } \\
\text { clog or wooden fetters for captives; not }\end{array}$ & $8.6 \times 6$ \\
\hline $\begin{array}{l}\text { kandah; Ind: khorah for secondary } \\
\text { meaning }\end{array}$ & & $\begin{array}{l}\text { illustrated: dugout hole in the ground } \\
\text { for seeds }\end{array}$ & \\
\hline $\begin{array}{l}\text { meaning } \\
\text { kappi }\end{array}$ & $\begin{array}{l}244 \mathrm{D} \\
245 \mathrm{~b}\end{array}$ & $\begin{array}{l}\text { Ior seeas } \\
\text { ape, monkey }\end{array}$ & $\begin{array}{l}6.3 \times 6.6 \\
5.5 \times 7.8\end{array}$ \\
\hline gurbah bìd & $247 \mathrm{~b}$ & species of willow tree & $6.4 \times 6.6$ \\
\hline gūr & $248 b$ & wild ass or tomb* & $10 \times 12$ \\
\hline gurāz & 25 oa & hog or boar & $7 \cdot 3 \times 6$ \\
\hline garg and gulbānk & $251 \mathrm{~b}$ & wolf; the sound of the nightingale* & $7 \times 9.8$ \\
\hline silāḥ̄ & $252 b$ & Turkish horn & $7.8 \times 6.3$ \\
\hline gushn & $253 b$ & sex, conception, animal sex & $9.9 \times 12$ \\
\hline lūrak & $259 b$ & cotton bow & $7.6 \times 12.1$ \\
\hline latinak & $259 b$ & sharpening of the millstone & $7.4 \times 4.7$ \\
\hline lahfatān & $259 b$ & dolls & $7 \cdot 5 \times 8$ \\
\hline lawh pāy & $262 \mathrm{a}$ & foot treadle & $8 \times 12$ \\
\hline muhār & $265 b$ & reins for a camel & $5.7 \times 9.5$ \\
\hline majājang & $268 \mathrm{a}$ & dildo & $4.1 \times 7.3$ \\
\hline mang; Ind: amgrāā & $268 b$ & yawn & $6.3 \times 6.9$ \\
\hline mil (pronounced mul for "drink"- & & & \\
\hline related definition) & $269 a$ & hair & $6.4 \times 6.5$ \\
\hline mushkū & $27 \mathrm{ob}$ & palace built for Shirin & $10.6 \times 12 ; 6 / 4.6 \times 3.6 / 8.4$ \\
\hline maykadah & $271 \mathrm{a}$ & tavern & $10.7 \times 12 ; 1.8 / 8.9 \times 7.1 / 4.9$ \\
\hline māhiyānah & $271 \mathrm{~b}$ & fish eaten with bread & $8.2 \times 7 \cdot 3$ \\
\hline māshürah & $272 \mathrm{a}$ & reed used by weavers, syphon & $7.8 \times 5.2$ \\
\hline
\end{tabular}


TABLE OF PAINTINGS IN THE MIFTĀH $A L-F U \dot{Z} A L \bar{A}$ ', BRITISH LIBRARY OR 3299 (Cont.)

\begin{tabular}{|c|c|c|c|}
\hline $\begin{array}{l}\text { 1. Lemma in Persian and any } \\
\text { given Indic equivalents }\end{array}$ & 2. Folio of illustration & 3. Depicted definition & $\begin{array}{l}\text { 4. Dimensions } \\
(\mathrm{L} \times \mathrm{W} \mathrm{cm})\end{array}$ \\
\hline$m a \bar{k} h c h \bar{\imath}$ & $273 \mathrm{a}$ & half Turk and half Arab horse & $6.5 \times 7.1$ \\
\hline$n \bar{a} k h u d \bar{a}$ & $274 \mathrm{a}$ & captain of a ship & $8.3 \times 8.8$ \\
\hline nāchakh, Ind: apaharsī & & & \\
\hline (unattested) & $275^{b}$ & axe or double-headed spear* & $7.8 \times 12$ \\
\hline nimūr & $277 \mathrm{~b}$ & a hunt?, also a deer? & $8.6 \times 12.2$ \\
\hline naw āmūz & $278 b$ & new student & $7.6 \times 12$ and $8.2 \times 12$ \\
\hline navāsāz & $279 \mathrm{a}$ & $\begin{array}{l}\text { musician who plays a stringed instrument } \\
\text { long reed used for calling Christian }\end{array}$ & $8 \times 12$ \\
\hline$n \bar{a} q \bar{u} s$ & $279 b$ & worshipers & $7.7 \times 12$ \\
\hline$n \bar{a} z n \bar{i} n$ & $285 \mathrm{a}$ & $\begin{array}{l}\text { delicate, lovely } \\
\text { gift given to children after finishing the }\end{array}$ & $7.4 \times 7.8$ \\
\hline nushrah & $286 \mathrm{a}$ & Qur’an & $8.4 \times 12$ \\
\hline nayshah; Ind: bānslī & $288 \mathrm{a}$ & small reed & $8 \times 12$ \\
\hline vāzanch; Ind:penga (unattested) & $291 \mathrm{a}$ & swing & $\begin{array}{l}9.5 \times 12 \\
18 \times 12 ; 7.3 \times 12 ; \text { space: } 4.6\end{array}$ \\
\hline $\begin{array}{l}\text { Waqwāq } \\
\text { vanang; Ind: lakanī, (laganī })\end{array}$ & $293 a$ & Island or tree of Waqwāq & $\mathrm{x} 12 ; 6.1 \times 12$ \\
\hline (unattested) & $294 \mathrm{a}$ & line upon which grapes are hung & $3.7 \times 12$ \\
\hline varkāl & $294 b$ & wild bird & $8 \times 7.4 ; 1.4 / 6.6 \times 5.6 / 1.9$ \\
\hline$y \bar{u} z$ & $302 b$ & small dog, leopard, to search* & $6 \times 12$ \\
\hline yang & $304 a$ & law & $8.4 \times 9.1$ \\
\hline
\end{tabular}

